\title{
MODIFIED SULFUR CEMENT SOLIDIFICATION OF LOW-LEVEL WRSTES
}

\section{TOPICAL REPORT}

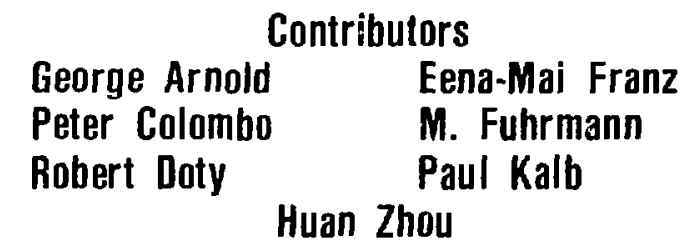

Submitted April 1985

Revised October 1985

\section{NUCLEAR WASTE RESEARCH GROUP} DEPARTMENT OF NUCLEAR ENERGY BROOKHAVEN NATIONAL LABORATORY

ASSOCIATED UNIVERSITIES, !NC. UPTON. LONG ISLAND. NEW YORK 11973

Prepared for the UNITED STATES DEPARTMENT OF ENERGY

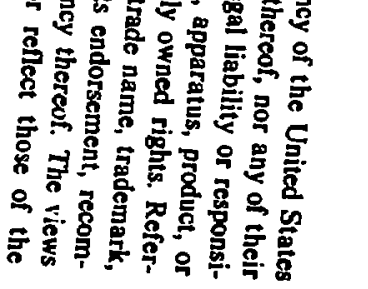




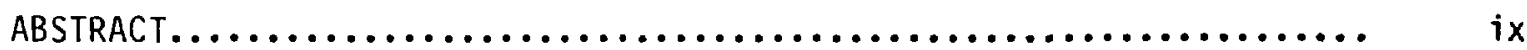

1. INTRODUCTION......................................... 1

2. MODIFIED SULFUR CEMENT SOLIDIFICATION OF LOW-LEVEL WASTE........ 2

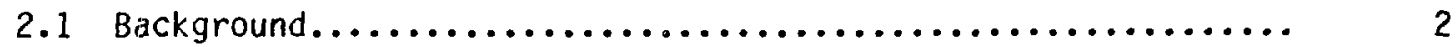

2.2 Structure of Elemental Sulfur....................... 2

2.3 Structure of Modified Sulfur Cement................... 4

2.4 Commercial Production of Modified Sulfur Cement............ 8

3. WASTE TYPES INVESTIGATED........................... 10

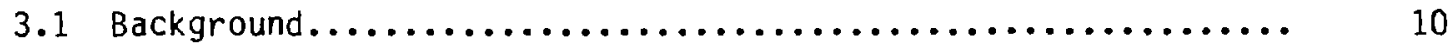

3.2 Volume Reduction Wastes.......................... 10

3.3 "Problem Wastes"................................ 11

4. PROCESS OEVELOPMENT STUDIES.......................... 12

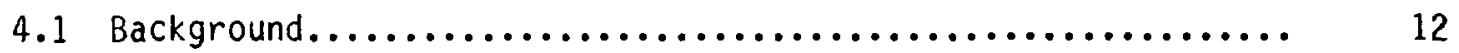

4.2 Preparation of Simulated Wastes...................... 12

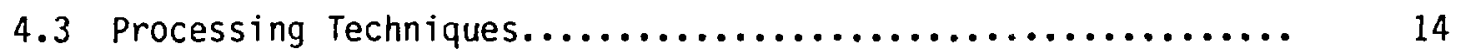

4.3 .1 Screw Extruder............................. 14

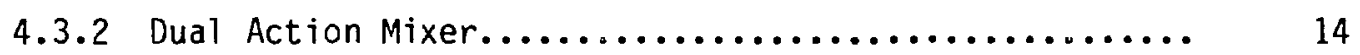

4.4 Waste Binder Compatibility....................... 16

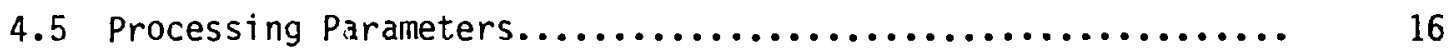

4.5 .1 Temperatures................................ 19

4.5.2 Waste Pre-Treatment.......................... 19

4.5 .3 Solidification Kinetics....................... 19

4.6 Process Developme،it Results.......................... 20

4.6 .1 Solidification of Sodium Sulfate................. 20

4.6 .2 Solidification of Boric Acid................... 21

4.6.3 Solidification of Incinerator Ash................ 22

4.6.4 Solidification of Ion Exchange Resins.............. 22 
4.7 Waste Form Quality Assurance..................... 22

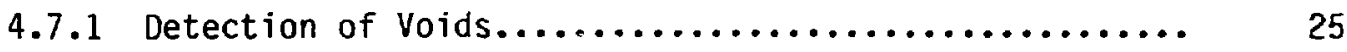

4.7 .2 Resistance to Spalling...................... 25

4.7 .3 Waste Form Homogeneity..................... 25

5. WASTE FORM PROPERTY EVALUATION STUDIES................... 31

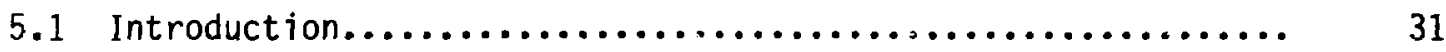

5.2 Compressive Stirength............................ 32

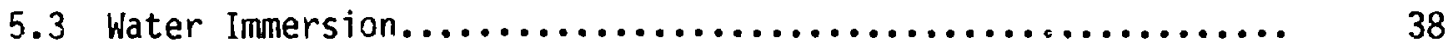

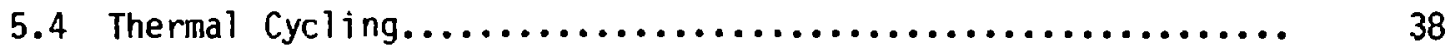

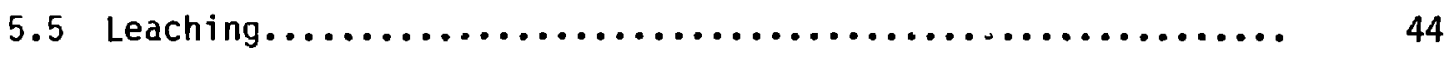

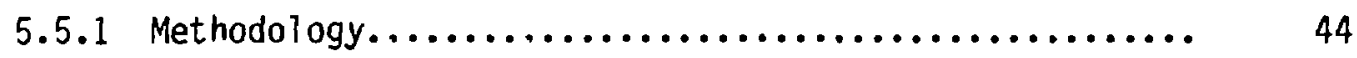

5.5 .2 Sample Preparation......................... 49

5.5 .3 Experimental Procedure....................... 49

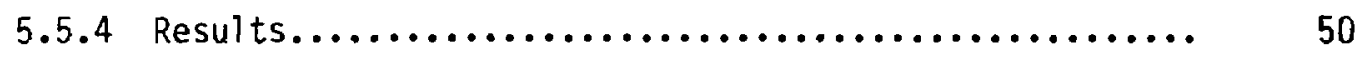

6. SUMMARY AND CONCLUSION........................... 57

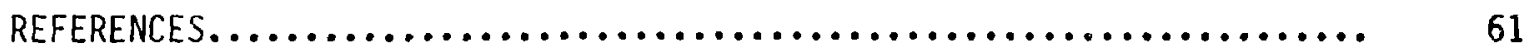

APPENDIX A Extruder Process Parameters for Representative Modified Sulfur Cement Waste Forms

APPENDIX B Dual Action Mixer Process Parameters for Representative Modified Sulfur Cement Waste Forms

APPENDIX C Tabular Leaching Data 


\section{LIST OF TABLES}

$\underline{\text { Page }}$

Table No.

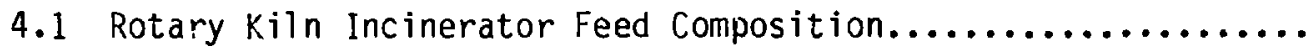

4.2 Summary of Maximum Waste Loadings for Modified Sulfur Cement Waste Forms Achieved During Process Deve? opment Studies........................................

4.3 Modified Sulfur Cement Waste Form Densities............... 28

5.1 Modified Sulfur Cement Waste Form Compressive Strength Results........................................

5.2 Modified Sulfur Cement Waste Form Compressive Strength Upon Completion of Water Immersion Test..................

5.3 Modified Sulfur Cement Waste Form Compressive Strength for Thermal cycled Specimens..........................

5.4 Average Leachability Index Values for Modifiea Sulfur

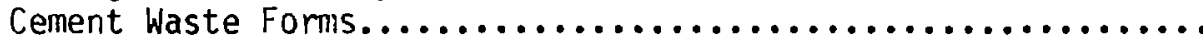

6.1 Comparison of Optimal Recommended Waste Loadings for Modified Sulfur Cement, Hydraul ic Cement and Polyethylene Based on Processing and Waste Form Performance Considerations.........

6.2 Percentage Iinprovement or Reduction in Waste Loading for Modified Sulfur Cement Versus Hydraulic Cement and Pol yethylene...................................... 


\section{LIST OF FIGURES}

Figure No.

Page

2.1 Modified Sulfur and Portland Concrete Specimens Upon

Exposure to Acid for 2 Weeks...........................

2.2 Thermal Stability Profile for Various Modified Sulfur

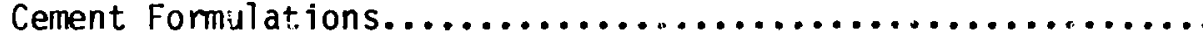

2.3 Differential Scanning Calorimeter (DSC) Themograms

Comparing Elemental Sulfur and Several USBM Modified

Sulfur Cement Formulations. Curve "B" Corresponds to

Sulfur Cement Formulation Employed in this Study..............

2.4 Differential Scanning Calorimeter (DSC) Thermogram of Commercially Available Modified Sulfur Cement from a Batch

Employed in Waste Form Process Development Studies...........

4.1 Single Screw Extruder Used in the Production of Laboratory

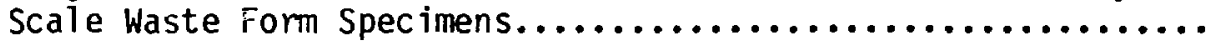

4.2 View of Dua? Action Heaced Mixing Vessel for the Production of Laboratory Scale Modified Sulfur Cement Waste Forms, Shown

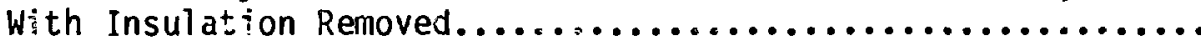

4.3 Dual Action Heating Mixing Vessel Shown With Cover Removed,

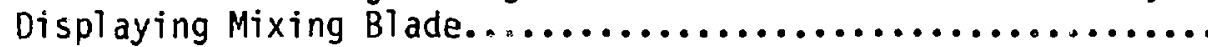

4.4 Modified Sulfur Cement Waste Forms Containing 35, 40 and 50 wt $\%$ Boric Acid Waste (No. 1, 2, 3, respectively) Which were Processed at $>169^{\circ} \mathrm{C}$. Surface Spalling and Cracking Occurred Upon Exposure to Ambient Laboratory Humidity Conditions .................................

4.5 Modified Sulfur Cement Waste Forms Containing 20, 30 and 40 wt\% Boric Acid Waste (No. 6, 7 and 8 , respect ively) Processed at $121-122^{\circ} \mathrm{C}$

4.6 Cross-Sectional View of a Neat Modified Sulfur Cement Specimen, Displaying Void Cavity Formed Upon Cooling..........

4.7 Modified Sulfur Cement Specimens Containing (From Left to Right), 0, 10, 20, 30 and 40 wt\% Ion Exchange Resins, Upon Exposure to Ambient Laboratory Humidity Conditions............

4.8 Modified Sulfur Cement Waste Form Apparent Density as a function of Waste Loading. Data Represent the Mean for Three Replicates, Bracketed by Minimum and Maximum Values.....

5.1 Modified Sulfur Cement Waste Form Test Specimen Undergoing Compressive Strength Test........................... 
Figure No.

5.2 Compressive Strength as a Function of Waste Loading for Modified Sulfur Cement Waste Forms Containing Sodium Sulfate and Boric Acid Wastes. Data Foints Represent the Mean, and Error Bars the Range of Measured Values.........

5.3 Compressive Strength is a Function of Waste Loading for Modified Sulfur Cement Waste Forms Containing Incinerator Ash Waste. Data Points Represent the Mean, and Error Bars

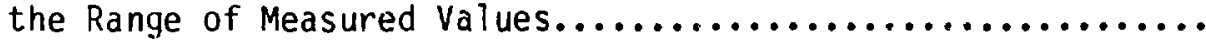

5.4 Modified Sulfur Cement Waste Form Specimens Containing $30 \mathrm{wt} \%$ Incinerator Ash Before Testing (Right) and After

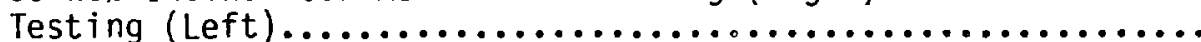

5.5 Modified Sulfur Cement Waste Form Incorporating 10 wt\% Dry Ion Exchange Resin While Undergoing a Water Immersion Test. All Three Photographs are of the Same Sample, Taken Within Five Minutes of the Initiation of the Test. Complete Structural Failure of the Sample was Observed in

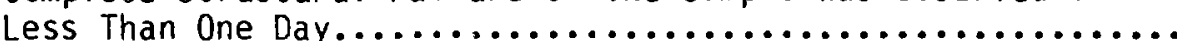

5.6 Modified Sulfur Cement Waste Forms Containing 50 wt\% Sodium Sulfate Showing Crack Formation After 65 Days in Water Immersion. Further Degradation 0ccurred During the Remainder of the 90 Day Water Immersion Test.............

5.7 Modified Sulfur Cement Waste Forms Containing $40 \mathrm{wt} \%$ Sodium Sulfate Shown After 65 Days in Water Immersion. Upon Completion of the 90 Day Water Immersion Test no

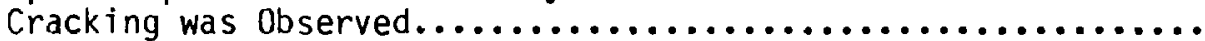

5.8 Histogram Comparing Results of Compressive Strength Measurements for Standard and Water Immersion Specimens.......

5.9 Photograph of Microprocessor Controlled Thermal Cycle Environmental Chamber for Conditioning Specimens According

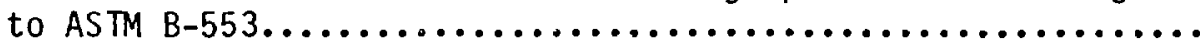

5.10 Graphical Representation of Temperature Conditions and

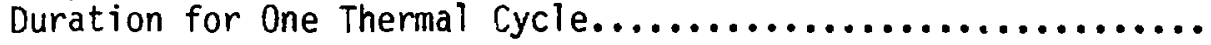

5.11 Histogram Comparing Compressive Strength for Standard and Thermal Cycled Specimens.............................. 


\section{LIST OF FIGURES (cont.)}

Figure No.

5.12 Cumulative Fractional Cesium Release for Modified Sulfur Cement Waste Forms Containing 20 and 40 wt\% Sodium Sulfate....

5.13 Cumulative Fractional Cobalt Release for Modified Sulfur Cement Waste Forms Containing 20 and 40 wt\% Sodium Sulfate....

5.14 Cumulative Fractional Cesium Release for Modified Sulfur Cement Wasie Forms Containing 20 and 40 wt\% Incinerator Ash...

5.15 Cumulative Fractional Cobalt Release for Modified Sulfur Cement Waste Forms Containing 20 and 40 wt\% Incinerator Ash.... 


\section{ABSTRACT}

This topical report describes the results of an investigation on the solidification of low-level radioactive wastes in modified sulfur cement. The work was performed as part of the Waste Form Evaluation Program, sponsored by the U.S. Department of Energy's Low-Level Waste Management Program.

Modified sulfur cement is a thermoplastic material developed by the U.S. Bureau of Mines. Processing of waste and binder was accomplished by means of both a single-screw extruder and a dual-action mixing vessel. Waste types selected for this study included those resulting from advanced volume reduction technologies (dry evaporator concentrate salts and incinerator ash) and those which remain problematic for solidification using contemporary agents (ion exchange resins).

Process development studies were conducted to ascertain optimal process control parameters for successful solidification. Maximum waste loadings were determined for each waste type and method of processing. Property evaluation testing was carried out on laboratory scale specimens in order to compare with waste form performance for other potential matrix materials. Waste form property testing included compressive strength, water immersion, thermal cycling and radionuclide leachability.

Recommended waste loadings of 40 wt\% sodium sulfate and boric acid salts and $43 \mathrm{wt} \%$ incinerator ash, which are based on processing and performance considerations, are reported. Solidification efficiencies for these waste types represent significant improvements over those of hydraulic cements. Due to poor waste form performance, incorporation of ion exchange resin waste in mod$i$ ified sulfur cement is not recommended. 


\section{INTRODUCTION}

This investigation of modified sulfur cement as a potential radwaste solidification agent has been performed as part of the Waste Form Evaluation program, sponsored by the U.S. Department of Energy's Low-Level Waste Management Program. The primary objective of the Waste Form program is the application of materials and processes which are not currently employed in the United States for the improved solidification of low-level radioactive wastes (LLW).

A survey of potential agents was conducted during FY 1983 and modified sulfur cement was designated as a leading candidate for further investigationl,2. Selection criteria as outlined in the Letter Report to DOE 1 , were based on such considerations as compatibility with waste, material properties, solidification efficiency, ease of processibility and economic feasibility.

Modified sulfur cement is related to traditional hydraulic cements, e.g. portland cement, in name only. In contrast to hydraulic cement and other contemporary LLW binders such as thermosetting polymers, a chemically induced curing reaction is not required for solidification. As a thermoplastic material, modified sulfur cement can be heated above the melt temperature, combined with waste to form a homogenous mixture and allowed to cool forming a monolithic solid product. By el iminating solidification chemistry, processing is simplified and waste form quality assurance is less subject to variation due to slight changes in waste stream composition.

This topical report describes research and development efforts in the areas of modified sulfur cement waste form development and property evaluation testing. Simulated laboratory scale waste forms were produced encompassing a number of waste types. Two methods of processing waste and binder materials were investigated and their relative advantages and disadvantages are discussed. Relevant process control parameters necessary for successful solidification are defined and maximum waste loadings attainable are reported. Solidified waste form performance was evaluated through a series of laboratory property tests and compared with results obtained for several other materials. 


\section{CHARACTERIZATION OF MODIFIED SULFUR CEMENT}

\subsection{Background}

Interest in sulfur cement as an alternative to hydraulic cements dates back to the early 20 th century. Its corrosion resistant properties made it a candidate for potential use as a construction material in the chemical industry3. Product failures were encountered during the use of these early formulations, which have been attributed to internal stresses set up by changes in the crystalline structure upon cooling (see Section 2.2). Attempts to improve product durability by the addition of modifying agents were either unsuccessful or uneconomical.

Recently, mandated pollution abatement programs which require sulfur dioxide removal from combustion stack gasses have resulted in increased projections of the involuntary supply of sulfur. Sulfur is also a by-product recovered from the refining of natural gas and petroleum. By the year 2000, as much as $85-90 \%$ of all sulfur production will result frorn these clean-up operations, yielding over $5.0 \times 10^{6}$ tons per year 4 . In an attempt to develop new, commercially viable uses for this by-product material, the U.S. Bureau of Mines (USBM) initiated a Sulfur Utilization Program in 1972. Through their research efforts, a modified sulfur cement was developed employing readily available and relatively inexpensive chemical modifiers which significantly improve product durability. For the purposes of this study, a commercially available modified sulfur cement produced under USBM license, was used.

Compared with hydraulic portland cements, sulfur cement has a number of advantages. Sulfur concrete compressive and tensile strengths twice those of comparable portland concretes have been attained ${ }^{5}$. Full strength is reached in a matter of hours rather than several weeks. Concretes prepared using suifur cements are extremely resistant to most acids and salts. Sulfates, for example, which are known to attack hydraulic cements have little or no effect on the integrity of sulfur cement ${ }^{6}$. Figure 2.1 compares sulfur and portland concrete specimens after exposure to acid for two weeks ${ }^{7}$. Because of these properties, modified sulfur cement has been proposed for use as a paving material, and for the production of tanks, pipes and ocher structures where durable concretes are required.

\subsection{Structure of Elemental Sulfur}

The basic raw material of moditied sulfur cement is elemental sulfur. Sulfur, with an atomic weight of 32.06, has a number of allotropic forms in both the liquid and solid states. The two crystalline solid forms of sulfur which are important to the long term stabiity of sulfur material as a solidification agent are the orthorhombic form ( $\alpha$-sulfur) and the monoclinic form ( $\beta$-sulfur). The orthorhombic form has a melting point of $112.8^{\circ} \mathrm{C}$ and a specific gravity of 2.07 at $20^{\circ} \mathrm{C}$, whereas the monoclinic form has a melting point of $119^{\circ} \mathrm{C}$ and a specific gravity of $1.957^{\circ}$. Typically, natural sulfur and that which results from chemical separation is orthorhombic $(\alpha)$, sirice this form is stable below $95.6^{\circ} \mathrm{C}$. Monoclinic (B) sulfur is rare in nature but can be found in association with volcanic exhalative processes and with burning 


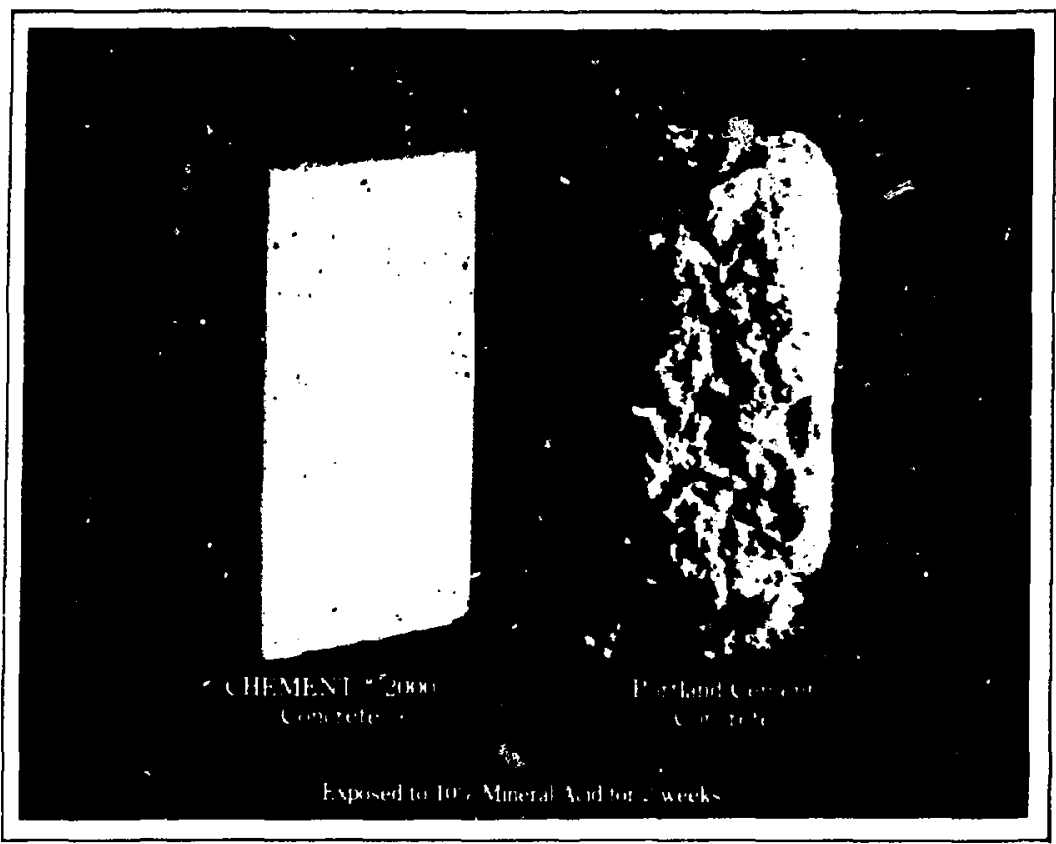

Figure 2.1 Modified Sulfur and Portland Concrete Specimens Upon Exposure to Acid for 2 Weeks. 
coal dumps ${ }^{9}$. With the allotropic transformation of $\beta$-sulfur to $\alpha$-sulfur, which occurs at a temperature of $95.6^{\circ} \mathrm{C}$, an increase in density results, creating residual stresses in the material. Fracturing will subsequently occur if the solid is shocked, for instance by impact or by thermal changes. Thus, it is desirable to retain the sulfur material in the monoclinic ( $\beta$ ) form in order to optimize structural characteristics.

\subsection{Structure of Modified Sulfur Cement}

Initial USBM attempts to devel op a modified sulfur cement involved the reaction of elemental sulfur with the unsaturated hydrocarbon dicyclopentadiene (DCPD). This material is commercially available at relatively low cost (approximately $\$ 0.08-0.12$ per pound, 1976) 10. Although product durability was enhanced, processing cifficulties were encountered due to an unstable exothermic reaction which, if uncontrolled resulted in extremely viscous mixtures. This exotherm results from the rapid depolymerization of DCPD to the monomeric form, cyclopentadiene (CPD) at the reaction temperatures of 120$140^{\circ} \mathrm{C}$ necessary for sulfur polymerization as depicted below ${ }^{11}$ :

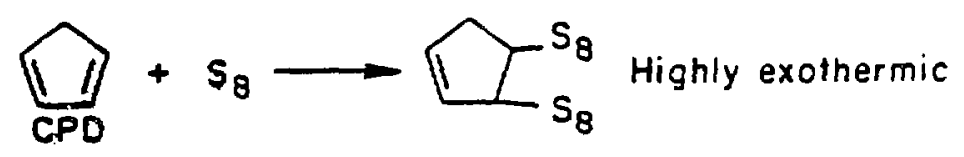

Remaining DCPD then reacts with the polysulfide product formed in Reaction 1, as seen below:

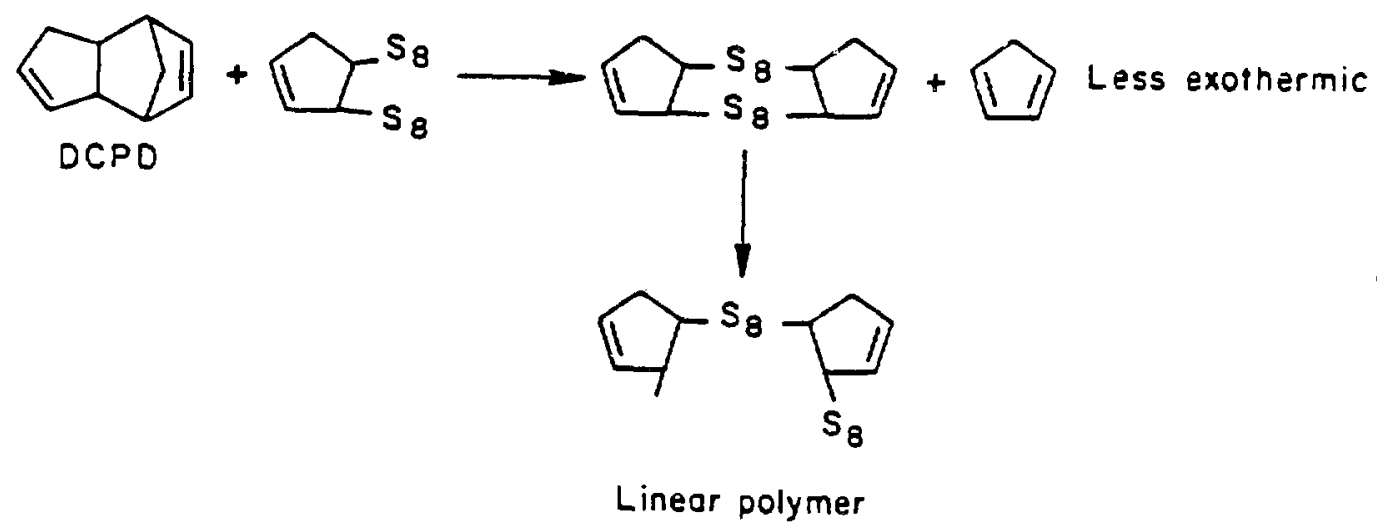


USBM researchers found that a mixed modifier system consisting of DCPD and the oligomer of cyclopentadiene (CPD) resulted in a lower exotherm, and thus, a more readily controlled reaction. The oligomer product is derived from the commercial production of DCPD resin and contains approximately $10 \%$ dimer and trimer, 20\% tetramer, $45 \%$ pentamer and $10 \%$ higher polymers. The reaction between oligomer and the polysulfide product of Reaction 1 is more stable as the oligomer breaks down slowly to form DCPD:

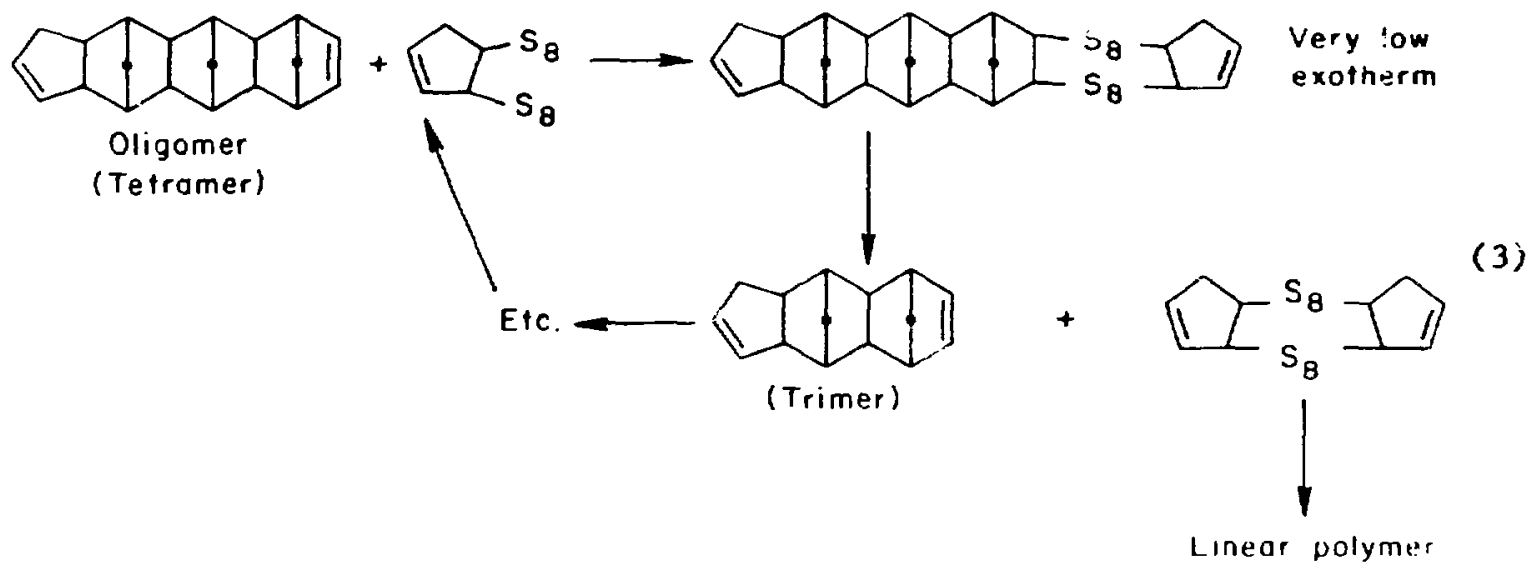

Further research was conducted by the USBM to determine the effects of varying the percentages of total modifier added, the relative proportions of modifier constituents, i.e. DCPD and CPD oligomer, and reaction methodologies. From the point of view of developing a useful construction material, the USBM selected a formulation containing $5 \mathrm{wt} \%$ modifiers consisting of equal parts of DCPD and an oligomer of CPD. This formulation yields a product of low viscosity upon melting, an advantage for mixability and handling considerations. Varying compositional parameters results in modified sulfur cements with a wide range of properties. Formulations developed with an increased proportion of modifiers (from 10-40 wt\%) and varying ratios of DCPD/oligomer produced higher viscosity end products which were more elastic in nature than those containing 5 wt\% modifiers.

The effects of various modifior formulations on the final viscosity of the mixture are seen in the thermal stability profiles in Figure 2.2. The most stable formulation is that of the 5 percent mixture of equal parts DCPD and oligomer which yields a flat profile with a final viscosity of $28 \mathrm{cp}$ at $135^{\circ} \mathrm{C}$ after over 30 hours reaction time. In contrast, the formulation containing only DCPD is quite unstable with a sharply increasing viscosity measured at $>450 \mathrm{cp}$ at $135^{\circ} \mathrm{C}$ after 12 hours reaction time.

The effects of various formulations on the structural behavior of modified sulfur cement is compared with elemental sulfur in Figure 2.3. These differential scanning calorimeter (DSC) thermograms indicate the quantity of thermal energy absorbed as the sample specimen is heated at a controlled rate. For the elemental sulfur and the DCPD modified sulfur (curves $A$ and $D$, respectively), a peak representing the solid phase transformation from orthorhombic 


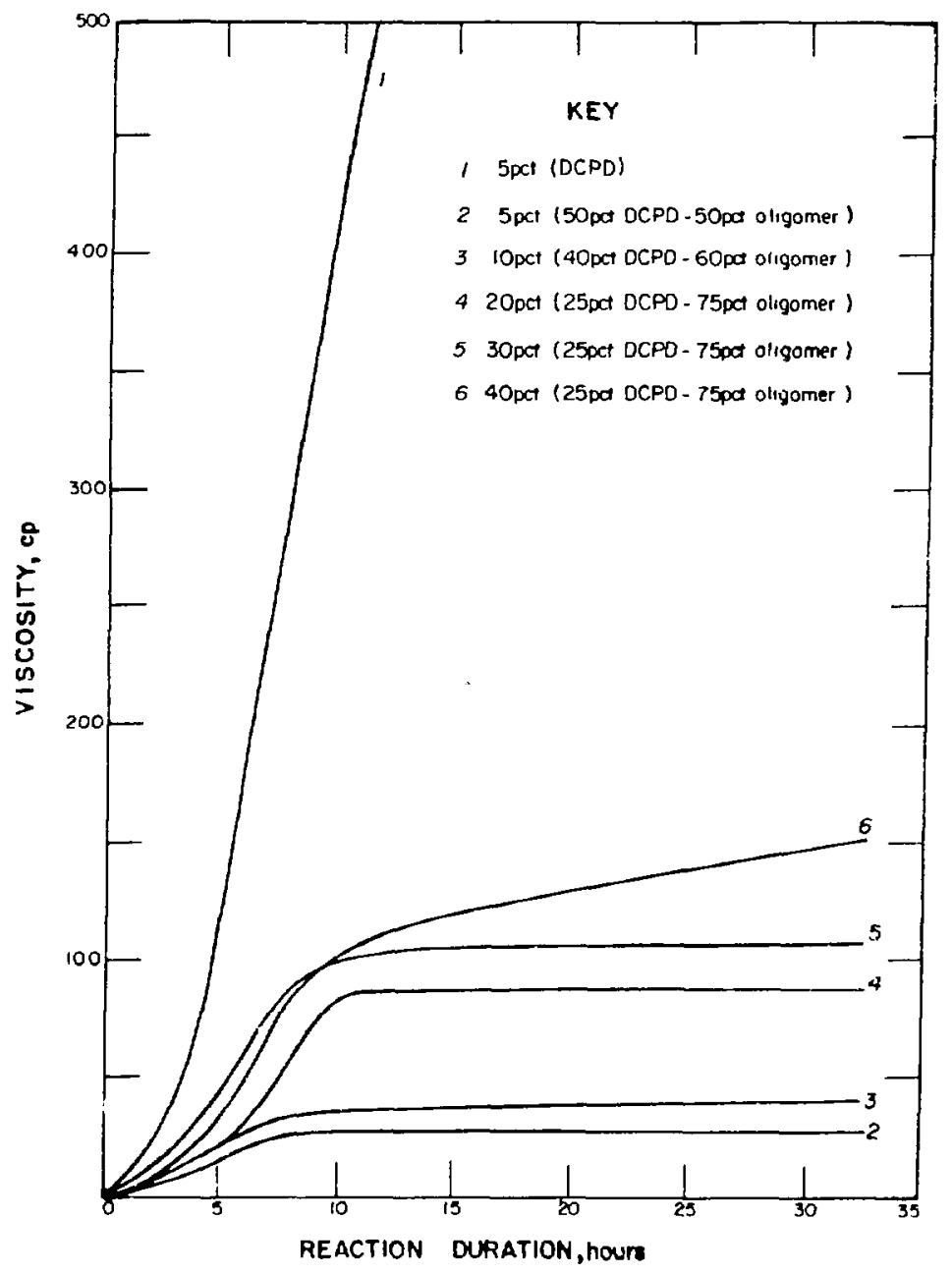

Figure 2.2 Thermal Stability Profile for Various Modified Sulfur Cement Formulations. Reference 11. 


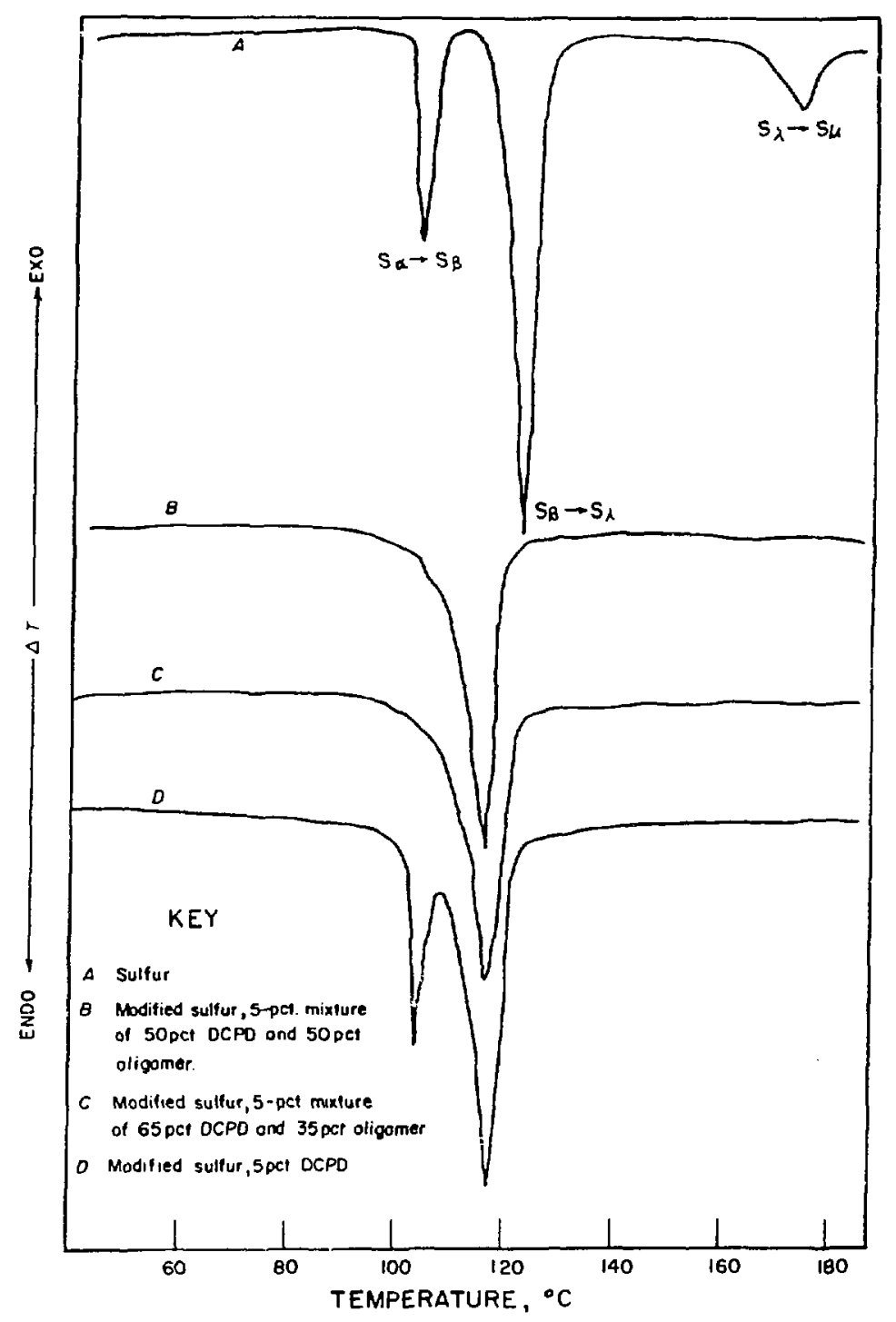

Figure 2.3 Differential Scanning Calorimeter (DSC) Thermograms Comparing Elemental Sulfur and Several USBM Modified Sulfur Cement Formulations. Curve " $B$ " Corresponds to Sulfur Cement Formulation Employed in this Study. 11 
(a) to monoclinic ( $\beta$ ) forms is evident at $104^{\circ} \mathrm{C}$, as well as the peak at approximately $119^{\circ} \mathrm{C}$, representing transformation to the liquid state. Those formulations containing mixtures of DCPC and oligomer (curves B and C) indicate that the solid phase transformation has successfully been eliminated.

\subsection{Commercial Production of Modified Sulfur Cement}

The modified sulfur cenent utilized in this investigation was manufactured "y Chemical Enterprises, Inc., Houston, Texas and is marketed under the tradename Chement 2000. Chemical Enterprises, Inc. is licensed to produce the USBM formulation of 5 wt\% modifier concentration with DCPD/oligomer ratio = 1.0. Although other 1 icenses have been issued, they are currently the sole commercial producer.

Dual steam heated reactor vessels with a combined capacity of 18 tons of molten sulfur are used for the processing of Chement 2000. Molten elemental sulfur is reacted with the modifier mixture at $140 \pm 5^{\circ} \mathrm{C}$ under constant stirring for a total of four hours. The material is then fed to a water cooled belt where it solidifies, is chopped into $1 / 8$ inch thick diameter particles and is packed in 50 pound bags for shipment.

As the production of modified sulfur cement is accomplished by batch processing, the end-product properties may vary slightly from batch to batch. This phenomenon can be seen in the DSC thermogram performed at BNL on a sample of Chement 2000 as shown in Figure 2.4. The minor peak at $104^{\circ} \mathrm{C}$ can presumably be attributed to either a small percentage of unreacted elemental sulfur present in this batch, or the slow transformation of some of the sulfur from a monoclinic to an orthorhombic structure oyer time. Since USBM testing has shown no change in modified sulfur cement structure at intervals of 14 and 21 months, the a peak is most likely due to traces of unreacted sulfur. 


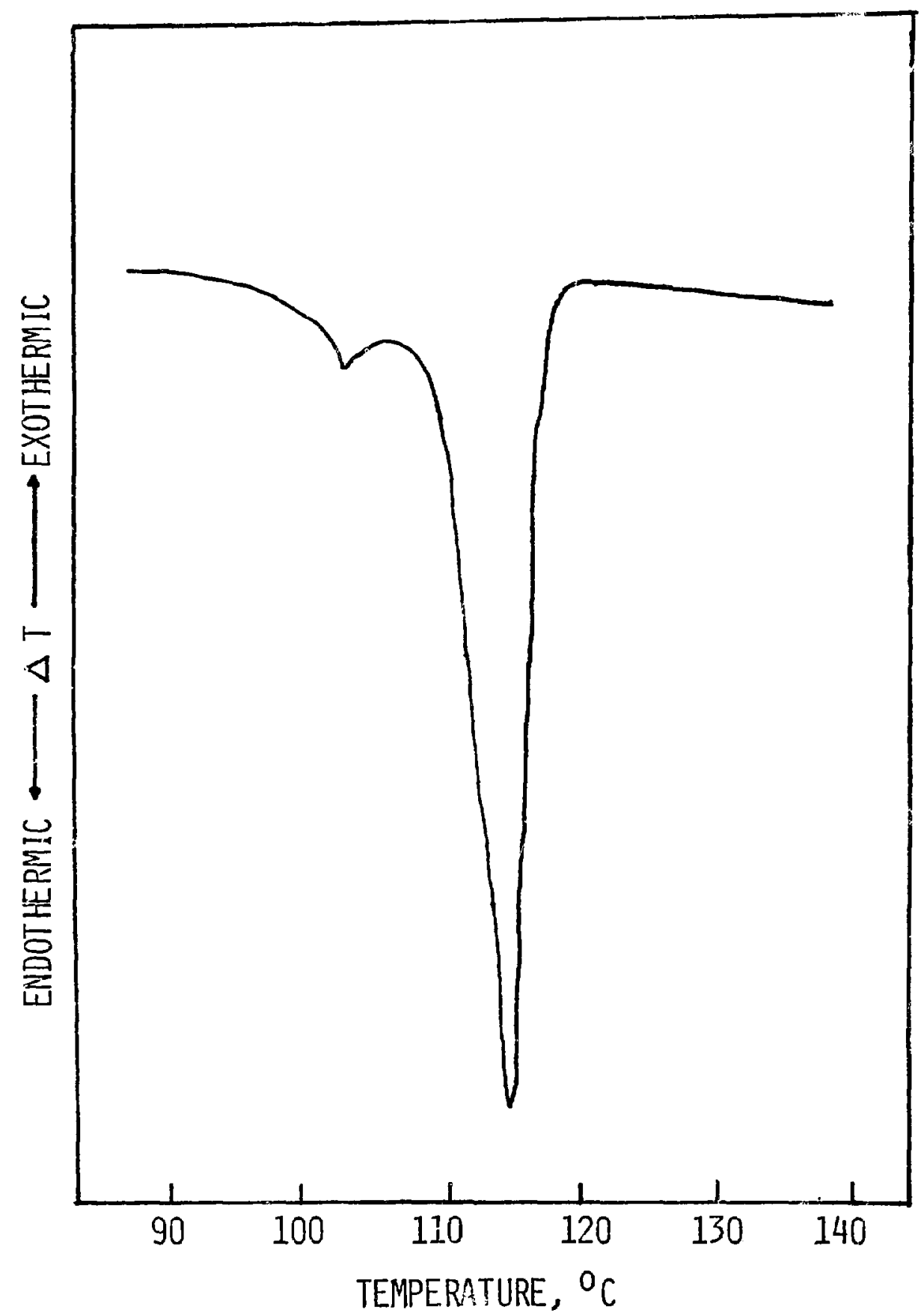

Figure 2.4 Differential Scanning Calorimeter (DSC) Thermogram of Commercially Available Modified Sulfur Cement from a Batch Employed in Waste Form Process Development Studies. 


\section{WASTE TYPES INVESTIGATED}

\subsection{Background}

Large volumes of low-level radioactive waste are routinely generated through the operation of defense-related and commercial nuclear facilities. In 1982, DOE/defense activities produced some $89.1 \times 10^{3}$ cubic meters of LLW, whereas, the commercial sector generated $75.9 \times 10^{3}$ cubic meters 12 . These wastes are diverse in chemical and physical composition, but can broadly be defined as either aqueous or dry active wastes (DAW).

Aqueous wastes consist primarily of fission and activation products removed from process streams to reduce radiation and/or contamination hazards to plant personnel. A nu.ber of processing techniques are employed to remove radioactive elements from these streams such as ion exchange, evaporation, reverse osmosis, flocculation, and filtration. Each of these techniques, while effective for the removal and concentration of activity, still result in some form of radioactive waste which must ultimately be disposed. Waste streams thus produced include ion exchange resins, evaporator concentrates, filtration sludges, and contaminated filters and membranes. According to current NRC regulations container in 10 CFR 61 , all 1 iquid waste streams must be stabi1$i$ zed by either solidification or use of a high integrity container13. An increased emphasis on waste stabilization is also being promulgated by DOE for the treatment and disposal of defense related waste streams.

Dry ac' ive wastes are produced at virtually all facilities involved with nuclear materials. These wastes such as paper, rags, clothing and plastics are currently compacted in 55 gallion drums or larger vessels. Many of these wastes however may be incinerated with a large reduction in waste volume resulting.

Waste streams selected for this investigation as reported in the Letter Report to DOE 14, and reviewed in the sections following include, 1) those which result from advanced volume reduction technologies (for both aqueous and dry active wastes), and 2) those which continue to be problematic for solidification using contemporary materials and processes.

\subsection{Volume Reduction Wastes}

Solidification efficiencies for aqueous concentrate wastes encapsulated using contemporary agents are often limited by chemical interactions between the waste and binder. Advanced volume reduction processes such as fluidized bed calciner's are now available which can reduce these liquid concentrates to a dry solid condition. By doing so, waste stability is improved and aqueous waste volumes can be reduced by factors ranging between six and twelve (depending upon original waste composition)15. Combustible dry active wastes can be treated by a number of currently available incineration technologies including rotary kiln, controlled air, fluidized bed, molten salt, cyclone and pyrolysis incineration. Depending upon the process and the composition of the waste input, incineration can achieve reductions in waste volume of as much as 100-fold 16 . 
In addition to increased siability, the benefits inherent in the use of advanced volume reduction of low-level waste include:

- Extension of current and future shallow land buria? capacity.

- Reduction in over-the-road shipments of radioactive waste.

- Potential overall cost savings for the disposal of LLW.

For these reasons, it is felt that the use of volume reduction technologies will become increasingly prevalent. As such, the incorporation of the resulting dry solid residues in modified sulfur cenent is covered in this study.

\section{3 "Problem" Wastes}

Due to their excellent sorption capacities, ion exchange resins serve a number of vital functions in the effective operation of nuclear facilities. Although resin wastes account for a relatively small fraction of $L L W$ on the basis of volume, they contain a significant fraction of the radioactiviity 17. Hydraulic cement is commonly used for the solidification of spent ion exchange resins. However, due to physicochemical interactions between the resin and cement which cause severe degradation of waste form mechanical integrity, waste loading efficiencies tend to be poor. In earlier studies performed at BNL it was shown that a maximum of approximately 13 weight percent dry ion exchange resins could be successfully incorporated in portland cement 18 . Ion exchange resins are therefore considered a "problem waste" and are included in this study.

In summary, waste form development and property evaluation studies for modified sulfur cement have been performed incorporating the following waste types:

- sodium sulfate evaporator concentrate salts

- boric acid evaporator concentrate salts

- incinerator ash

- ion exchange resins

Preparation of simulated wastes for use in process development and property evaluation studies are discussed in Section 4.2 . 


\section{PROCESS DEVELOPMENT STUDIES}

\subsection{Background}

Modified sulfur cement is a recently developed material for which little industrial experience is available. Furthermore, its application as a potential binder material for $10 w-l$ evel radioactive wastes had been previously untried. Investigation of processing requirements leading to successful encapsulation of LLW products was therefore a necessarily significant portion of the total project effort. Process development studies were conducted for modiried sulfur cement in order to:

- select the optimal processing technology

- verify waste-binder compatibility

- determine processing parameters of interest

- ascertain the effects of these parameters on the successful ericapsutation of various waste streams

- optimize process parameters to achieve maximum waste form volumetric efficiencies

- develop a data base of relevant laboratory-scale process control information to be used as a basis for the production of larger scale waste forms.

Modified sulfur cement is a thermoplastic material which melts at $119^{\circ} \mathrm{C}$ to form a low viscosity liquid. It is therefore amenable to a number of different methods of processing. Process development studies were performed using two methods: a screw extruder and a dual action heated mixer.

Unlike other thermoplastics such as polyethylene, sulfur is not inert and potential chemical interaction with waste constituents was a primary concern. In some cases, compatibility is a function of waste loading and/or process conditions.

Successfut production of modified sulfur cement waste forms is dependent upon control of processing parameters within a finite operating range. Addition of waste products of diverse physicochemical composition may alter these processing requirements. For each processing method, relevant parameters are identified and optimized for waste form volumetric efficiency, i.e., the quantity of waste which can successfully be solidified.

\subsection{Preparation of Simulated Wastes}

Laboratory scale waste forms were fabricated for both process development and property evaluation studies using non-radioactive, simulated wastes. Materials were selected which closely resemble actual wastes in both physical and chemical composition. 
Evaporator concentrates which have been brought to a dry solid state were simulated using anhydrous sodium sulfate $\left(\mathrm{Na}_{2} \mathrm{SO}_{4}\right)$ reagent and orthoboric acid $\left(\mathrm{H}_{3} \mathrm{BO}_{3}\right)$ reagent. The antual form of boric acid produced through volume reduction is dependent upon treatment conditions. When processed at temperatures in excess of $170^{\circ} \mathrm{C}$ metaboric acid results. It should also be noted that compositional variations in specific waste feed streams may alter the chemical form of volume reduction wastes. Both $\mathrm{Na}_{2} \mathrm{SO}_{4}$ and $\mathrm{H}_{3} \mathrm{BO}_{3}$ simulated waste were employed as a fine, dry powder with bulk densities of 2.68 and $1.44 \mathrm{~g} / \mathrm{cm}^{3}$ respectively.

Incinerator ash generated at the Rockwell International Rocky Flats Plant rotary kiln incinerator was employed as a typical volume reduction ash product. This ash was produced by burning simulated waste, with constituents equivalent to those present in actual combustible LLH from this facility as shown in Table 4.119 .

Table 4.1

Rotary Kiln Incinerator Feed Composition

\begin{tabular}{lc} 
Constituent & Weight $\%$ \\
\cline { 2 - 2 } Paper & 40.0 \\
Polyethylene & 22.8 \\
Neoprene & 18.8 \\
Kerosene & 9.5 \\
Polyvinyl Chloride & 7.9 \\
Tributyl Phosphate & 1.0
\end{tabular}

As received, the ash had a bulk density of approximately $0.23 \mathrm{~g} / \mathrm{cm}^{3}$. Since particle size was non-uniform the ash was put through a No. 8 sieve, resulting in a maximum particle size of $2.38 \mathrm{~mm}$. This procedure improved waste homogeneity.

Unloaded mixed-bed ion exchange resin beads manufactured by Rohm and Haas Corp., Philadelphia, PA, were used to simulate reactor resins. A ratio of two parts cation resin (IRN-77) to one part anion resin (IRN-78) was selected as representative of a typical reactor demineralizer system. Resin bead particle sizes range between 0.5 and $1.0 \mathrm{~mm}$ in diameter. As-received resins (2:1 mixed-bed) have a density of approximately $1.21 \mathrm{~g} / \mathrm{cm}^{3}$ and contained approximately 58 percent inoisture by weight. Typically ion exchange resins at reactors are maintained in a slurry (containing about 80 weight percent moisture) to facilitate transfer operations. Prior to processing with modified sulfur cement, the resins were oven dried overnight at $110^{\circ} \mathrm{C}$. 


\subsection{Processing Techniques}

Processing of modified sulfur cement and waste components into a waste form product requires 1) heating of the components unt il the binder has completely melted, 2) mixing the constituents into a homogeneous molten slurry and 3) pouring into a suitable mold and cooling to a monolithic solid. These relatively simple processing requirements can be met by a number of different techniques. Those investigated for this project include a 1 1/4 inch diameter screw extruder and a dual action heated mixer. Each of these systems is described below, along with a discussion of their relative merits and limita$t$ ions. Comparisons of process development results for each method is included in Section 4.6

4.3.1 Screw Extruder. A Model KL-125 single screw extruder manufactured by Killion Extruders, Verona, NJ was employed for the production of 1 aboratory scale simulated waste forms. This machine is equipped with a $11 / 4$ inch diameter screw powered by a 3 horsepower d.c. drive electric motor. It is heated by a series of electrical resistance band heaters which are controlled by solid state time proportioning temperature controllers. Melt temperature, melt pressure, screw speed and current draw are monitored by appropriate instrumentation. Pre-measured quantities of waste and binder were mixed together and placed in the feed hopper prior to processing. A schematic view of the extruder is shown in Figure 4.1. Additional technical data pertaining to the extruder, as well as a discussion of the principles of extrusion technology are included in Reference 20.

Screw ext.rusion systems have been employed for processing thermoplastic materials for nearly 50 years. Their use in the plastics industry for the production of a wide range of products is common. Use of a proven and available processing method was one advantage considered in the selection of this system. In addition, since extrusion is a continuous rather than batch method, it provides advantages in terms of process efficiency.

Unlike polyethylene and other plastics commonly processed by extrusion, modified sulfur cement develops a low viscosity upon melting. This high degree of fluidity impeded conveyance through the extruder barrel which is accomplished by tine action of the rotating screw. Low melt viscosity also hampered the screw's ability to effectively mix the waste and binder constituents since mixing occurs upon mastication of the viscous melt between the barrel and screw.

4.3.2 Dual Action Mixer. Inherent limitations in the application of the extrusion process for use with modified sulfur cement as discussed above, led to the development of an aiternative technique. A mixing vessel was designed and fabricated, similar in principle to a system employed at ORNL for laboratory processing of bitumen waste forms 21 .

The dual action mixer consists of a stainless steel vessel with an internal diameter of $11.2 \mathrm{~cm}$ and height of $21.0 \mathrm{~cm}$, providing a capacity of just over 2 liters. The vessel is heated by a series of external resistance band heaters, controlled by a digital time proportioning temperature controller. A 


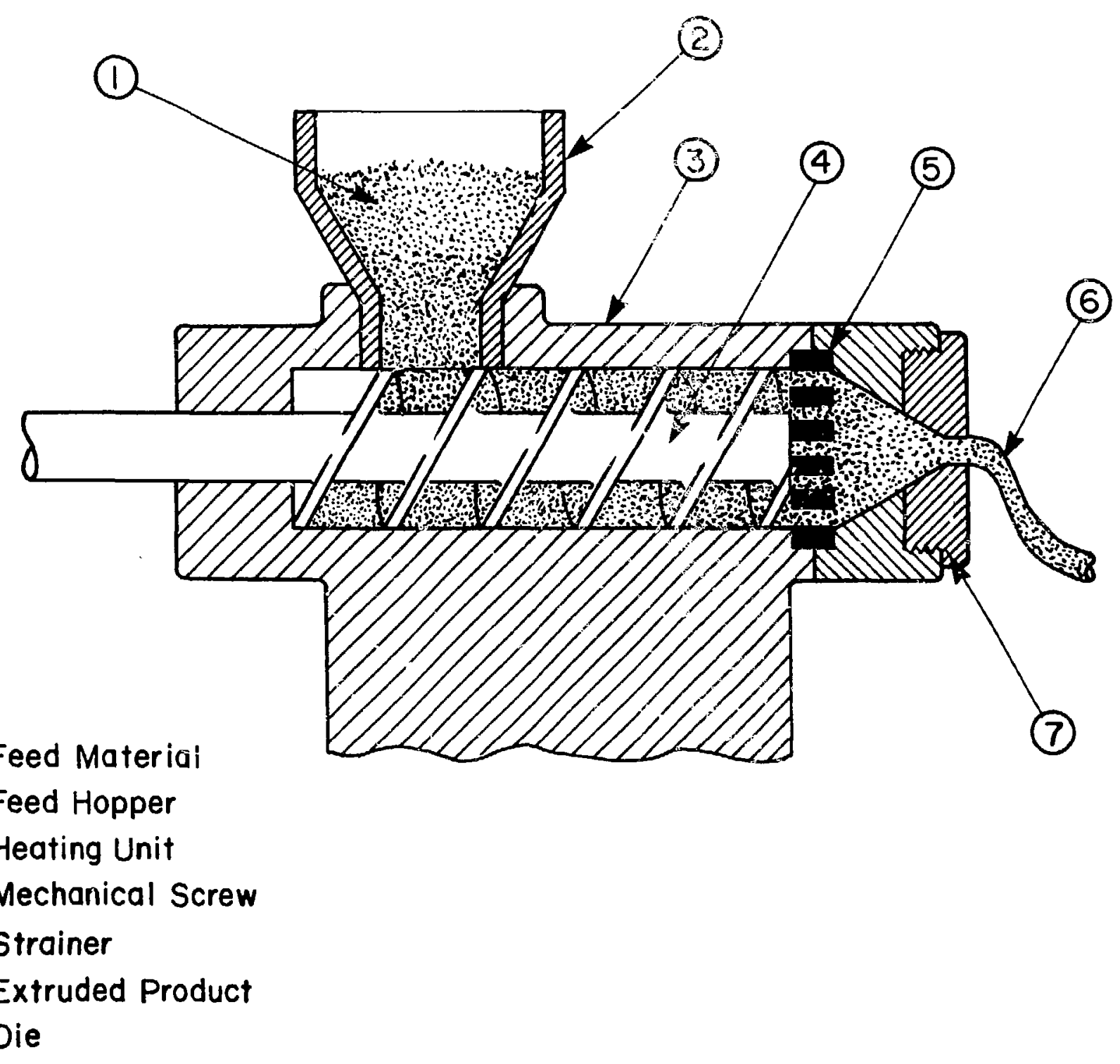

r:gure 4.1. Single-Screw Extruder Used in the Production of Laboratory Scale Waste Forms Specimerss. 
view of the mixer with external insulation removed can be seen in Figure 4.2 . Stirring of the waste-binder mixture is accomplished by the dual mixing action of a combination impeller b? ade and teflon wiper stirrer. The wiper blades are oriented at 180 degrees and are supported on the power shaft by a stainless steef' plate which has been drilled to promote interrial flow. The wipers serve to both stir the mixture and scrape the vessel's interior surface, reducing particle size and improving homogeneity. A standard 3 blade impeller at the base of the power shaft provides a vortex mixing action.

The mixer is powered by a high torque compressed air driven motor. A view of the vessel with the cover removed to display the mixing components is included in Figure 4.3. Delivery of the molten mixture is through a heated ball valve with inert gas pressurization assistance.

The order of addition of waste and binder components had an observable impact on the ease of processibility. Heating the combined waste-binder mixt.ure led to clumping and segregation of ingredients. Pre-melting of the modifier sulfur cement with tho gradual addition of waste solids provided a more workable mixture, especially for highe: waste loadings.

\section{\$.4 Waste-Binder Compatibility}

The compatibility of each waste type with modifieu sulfur cement was examined from the standpoint of botil processing requirements and final waste form performance characceristics. The impact of potential interactions between waste and binder as they relate to processing considerations are addressed in this section, while those which affect waste form performance are covered in Section 5 .

Under suitable conditions sulfur can chemically react with most elements and many inorganic, organic and organometalic compounds 22 . Only those reactions which involved liberation of water vapor such as the solidification of boric acid ard ion exchange resins had a measurable impact on processing.

In order to minimize potential reactions, process temperatures were maintained as low as practical. Processing of ortho boric acid $\left(\mathrm{H}_{3} \mathrm{BO}_{3}\right)$ at temperatures greater than $169^{\circ} \mathrm{C}$ results in a transition to meta boric acid $\left(\mathrm{HBO}_{2}\right)$ and the generation of water vapor. Ion exchange resins may contain as much as $70 \mathrm{wt} \%$ water as both interstitial and sorbed moisture, even after dewatering operations 23 . The bench scale extruder was not equipped with a venting apparatus, thus incorporation of water vapor created a pressure buildup and the formation of voids in the solidified mixture upon cooling. Although the design of the dual action mixer includes ventilation, in practice, wastes were pre-dried to expedite processing time. Formation of meta borate also led to deterioration of solidified waste forms, as discussed in Section 4.6.2. No adverse reactions were observed in processing sodium sulfate or incinerator ash with sulfur cement.

\subsection{Processing Parameters}

One of the advantages of employing a thermoplastic material for waste encapsulation is that as long as proper processing conditions are maintained, a monolithic solid waste form is assured upon cooling. Control of these process conditions is essential for production and can ultimately affect waste form performance. Due to its low melt temperature and viscosity, processing of 


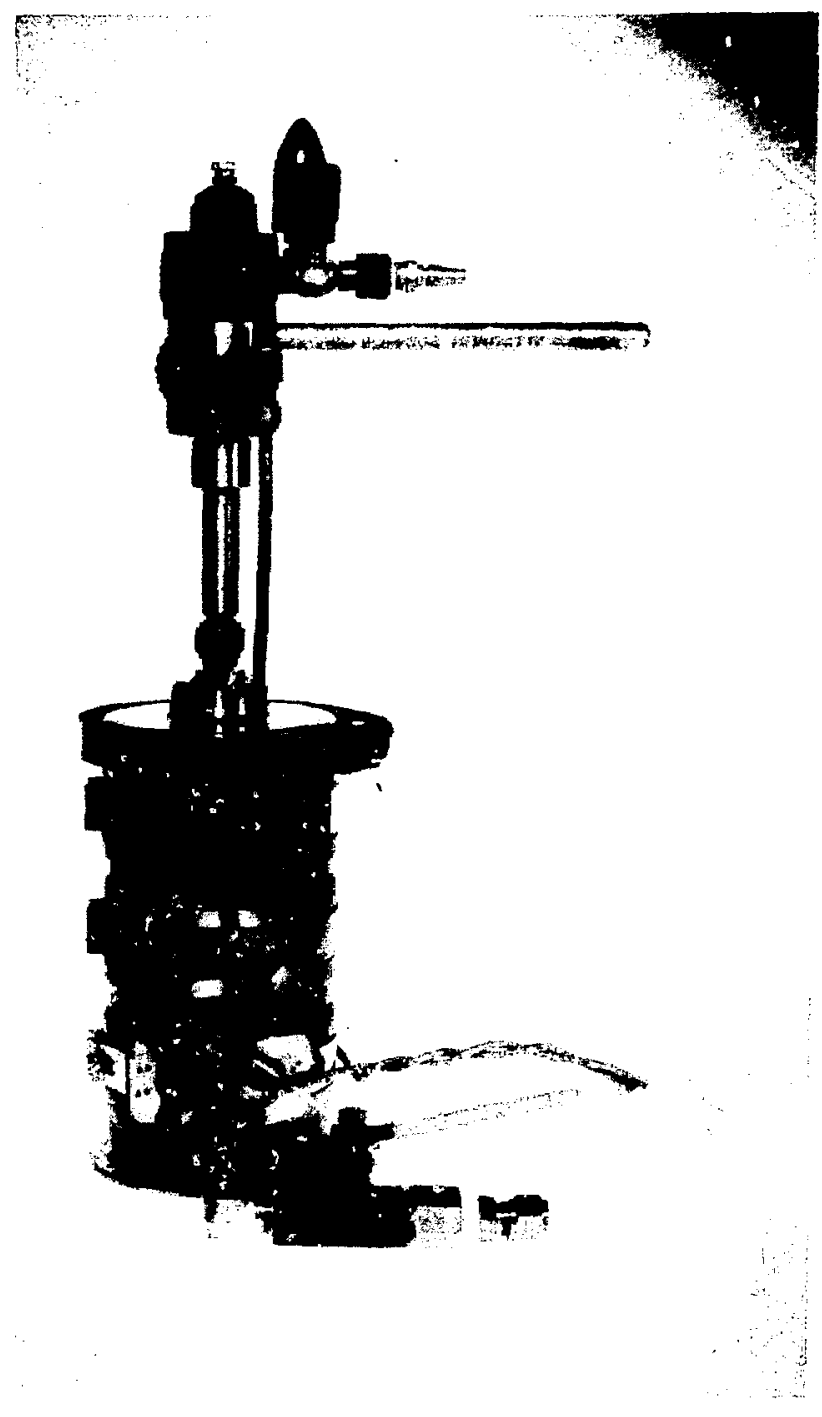

Figure 4.2 View of Dual Action Heated Mixing Vessel for the Production of Laboratory Scale Modified Sulfur Cement Waste Forms, Shown With Insulation Removed. 


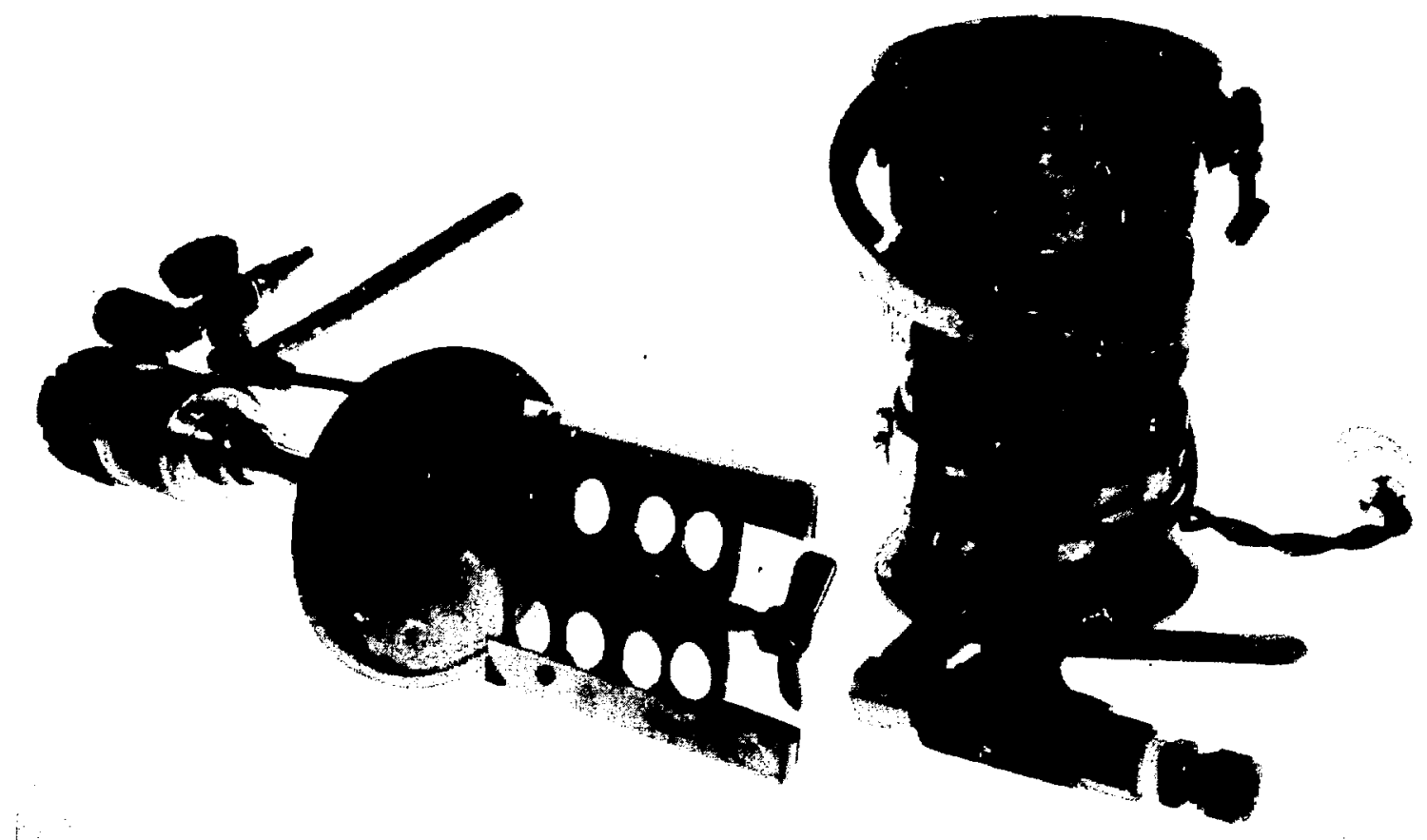

Figure 4.3 Dual Action Heating Mixing Vessel Shown With Cover Removed, Displaying Mixing Blade. 
modified sulfur cement is relatively less complex than other thermoplastics, such as polyethylene. Those parameters which were judged most important for the production of modified sulfur cement waste forms include:

- temperature

- waste pre-treatment

- solidification kinetics

4.5.1 Temperature. Temperature control of the waste-binder mixture is the most critical factor for processing modiried sulfur cement waste forms. From the standpoint of processing, temperature must be maintained above the melt point $\left(119^{\circ} \mathrm{C}\right)$, yet below the point at which additional polymerization occurs $\left(159.4^{\circ} \mathrm{C}\right)$, causing a sharp rise in viscosity 24 . Although use of modified sulfur cement suppresses this polymerization, presence of unreacted sulfur did cause observable variations in viscosity at temperatures higher than $160^{\circ} \mathrm{C}$. As discussed in Section 4.4, processing of boric acid waste at elevated temperatures caused the formation of meta borate and resulted in processing difficulties and poor product performance.

4.5.2 Waste Pre-Treatment. In certain cases waste pre-treatment was required for processing. As discussed in Section 4.2 , ion exchange resins were oven dried at $110^{\circ} \mathrm{C}$ overnight to drive off interstitial and sorbed moisture. This procedure is not required where sufficient venting is provided and/or adequate processing times are allowed to remove contained moisture. If moisture is not removed from the waste-binder mixture prior to cooling, entrapped vapors will create void spaces in the waste form. This will reduce product density and in turn, sacrifice loading efficieny and have an adverse effect on waste form strength and leachability.

4.5.3 Solidification Kinetics. The waste-binder mixture was extruded or poured into molds and allowed to air cool. Copper molds were employed initially but difficulties were encountered in removing the specimens, as the mixture tended to strongly adhere, especially when surface imperfections were present on the molds. The use of polyethylene molds fitted with copper heat sink sleeves allowed for easy removal of waste form specimens.

Cooling times were relatively rapid, (generally on the order of 15-30 minutes) due to the comparatively low specific heat capacity of the material (approximately $0.17 \mathrm{cal} / \mathrm{g}\left({ }^{\circ} \mathrm{C}\right)$ ). More rapid cooling induced by water bath or other means was avoided since quenching of sulfur results in additional allotropes which are uncharacteristically plastic in nature, but revert back to the brittle phase in a short time24. Modified sulfur cement without addition of waste solids tended to form a hollow void along the cylinder's axial centerline upon cooling. This phenomenon was due to the more rapid cooiling of the exterior of the specimen by convection, forming a rigid shell. The solid exterior restricts movement of the molten center as it begins to solidify and shrink, leaving a void in the center. Void formation decreased as the addition of waste solids increased, presumably due to higher specific heat capacities, reduced rate of cooling and reduced shrinkage. 


\subsection{Process Development Results}

Waste. form loading optimization was performed for each waste type and each processing system. Formulations were prepared with increasing quantities of waste until the limits of processibility were reached. Requisite process parameters for achieving these waste loadings are reported. It should be noted that waste loading results presented in this section are determined on the basis of processibility constraints. Consideration of waste form properties is presented in Section 5. Optimal waste loadings which reflect a compromise between loading efficiency and waste form performance are discussed in Section 6.

For the extruder, in some case these limits were ob erved when delivery of the waste-binder mixture from the output die ceased. If upon further examination, i.e. screw removal, the process shut down was attributable to blockages in the screw flights caused by a dry mixture, process limits were established. In other cases, extremely dry waste-binder mixtures resulted in excessive mechanical loading on extruder components which was monitored through the motor ammeter. If high amperage draw exceeded equipment specifications, an automatic safety shut-off was activated and process limits were established.

For the dual action mixer, maximum loading was also determined in one of two ways. For some waste-binder formulations, the power required to mix excessively viscous or dry mixtures would exceed the torque capacity of the motor. This would either stall the mixer or slow it to the extent that adequate homogenization was not possible. In other cases, excessive waste loadings created a dry, friable solid upon cooling, which lacked sufficient cohesiveness to form a monolithic solid.

A summary of maximum waste loadings for modified sulfur cement waste forms achieved during process development studies is presented in Table 4.2. Data are reported in terms of wt\% dry waste contained in the solidified waste forms, and serve as a comparison of results for the two processing systems under consideration.

4.6.1 Solidification of Sodium Sulfate. Processing of modified sulfur cement mixtures containing $30,40,50,60,65$ and 70 wt\% sodium sulfate were attempted by extrusion. No adverse conditions were encountered unt $\div 1$ the 70 wt\% formulation was run. At this point the screw became plugged with a dry powder containing insufficient binder to support conveyance through the barrel. Screw removal was required for cleaning before production could resume. Thus, the maximum sodium sulfate waste loading in modified sulfur cement by extrusion is reported at $65 \mathrm{wt} \%$. Extrusion process parameters for representative sodium sulfate fornulations are presented in Table A-1, Appendix A.

Modified sulfur cement waste forms containing $30,40,50,60,70,75$ and $80 \mathrm{wt} \%$ sodium sulfate were prepared by means of the dual action mixer. Above $60 \mathrm{wt} \%$ waste the mixture consisted of a dry past:e and additional mixing time was required for homogenization. Inert gas pressurization was insufficient to transfer these mixtures ( $>60 \mathrm{wt} \% \mathrm{Na}_{2} \mathrm{SO}_{4}$ ) to specimen molds, necessitating 
Table 4.2

Summary of Maximum Waste Loadings for Modified Sulfur Cement Waste Forms Achieved During Process Development Studies

Waste

Type

Sodium Sulfate

Boric Acid

Incinerator Ash

Ion Exchange Resin
Max. Loading

by Extrusion, wt\%

\author{
Max. Loading \\ by Dual Action Mixer, wt\%
}

65

40

20

40
80

57

43

$\mathrm{NA}(\mathrm{a})$

a) Not applicable; see Section 4.6.4.

scooping of the mix by hand. Attempts to process 85 wt\% sodium sulfate resulted in an extremely friable paste which could not be adequately mixed and crumbled upon removal from the specimen molds. Process parameters for sodium sulfate encapsulation by means of the dual action mixer are included in Table B-1, Appendix B.

4.6.2 Solidification of Boric Acid. Boric acid was solidified in modified sulfur cement by extrusion processing at waste loadings of $20,30,35$, and $40 \mathrm{wt} \%$ waste. Attempts to extrude greater quantities of this waste resulted in blockage of the extruder barrel. Extrusion process parameters for representative solidified boric acid formulations are presented in Table A-2, Appendix $A$.

Incorporation of $20,30,40,50$ and $57 \mathrm{wt} \%$ boric acid waste in modified sulfur cement was accomplished by means of the dual action mixer. Above 40 wt\% waste the mixture had a stiff consistency and required hand scooping in order to transfer it to specimen molds. Maximum waste loading ( $57 \mathrm{wt} \%$ ) was achieved by the slow addition of waste until the limits of workability were reached. Attempts to incorporate additional quantities of waste yielded mixtures which could not be successfully processed.

During the production of some boric acid specimens a malfunction in the temperature control system caused the melt temperatures to exceed $169^{\circ} \mathrm{C}$. As discussed in Section 4.4., this results in the formation of meta borate and a change in density from $1.435 \mathrm{~g} / \mathrm{cm}^{3}$ to $2.486 \mathrm{~g} / \mathrm{cm}^{3}$. Meta borate is extremely hygroscopic and the waste form specimens containing this compound tend to rapidiy sorb atmospheric moisture. In doing so, they rehydrate to their original ortho boric acid form, decrease in density and increase in volume, 
severely degrading waste form mechanical integrity. Three boric acid waste forms containing 35, 40 and $50 \mathrm{wt} \%$ waste, which experienced severe swelling upon exposure to atmospheric moisture are shown in Figure 4.4. In contrast, specimens containing 20,30 and 40 wt\% boric acid which were processed below $169^{\circ} \mathrm{C}$ display no signs of deterioration, as seen in Figure 4.5 .

4.6.3 Solidification of Incinerator Ash. Incinerator ash waste loadings in modified sulfur cement encapsulated by the extrusion method were limited to a maximum of $20 \mathrm{wt} \%$. The ash tended to sorb the molten binder, form clumps, and plug the channels of the screw. The mixing action of the screw was not vigorous enough to counteract this tendency, resulting in relatively low waste loadings. Extruder parameters for typical incinerator ash formulations at 10 and 20 wt\% waste are presented in Table A-3, Appendix A.

Significant improvements were realized by processing ash mixtures in the dual action mixer. By pre-melting the binder and slowly adding the incinerator ash waste, the tendency to clump was reduced. In addition, the dual action mixer provided more vigorous agitation and allowed increased mixing duration, further mitigating the problems encountered with the extrusion method. Formulations were prepared which incorporated 10,20,30, 40 and 43 wt\% incinerator ash. Attempts to incorporate additional ash waste resulted in unworkable mixtures. Representative parameters for these fomulations are given in Table B-3, Appendix B.

4.6.4 Solidification of Ion Exchange Resins. Initial processing of ion exchange resins in modified sulfur cement yielded formulations containing 10 , 20, 30 and $40 \mathrm{wt} \%$ waste. Extruding $50 \mathrm{wt} \%$ resins resulted in seizure of the screw. Extrusion process parameters for resin waste forms are given in Table A-4, Appendix A.

Several waste form performance scoping tests were peformed on representative ion exchange resin/modified sulfur cement specimens formulated during these initial runs. During short term ( 2 week) water immersion testing, swe1ling, cracking and complete loss of mechanical integrity was observed for all specimens containing resins, as discussed in Section 5.1. For this reason, further process development studies for the incorporation of ion exchange resins in modified sulfur cement were discontinued.

\subsection{Waste Form Quality Assurance}

Waste form process development studies incorporated a number of quality assurance tests in order to:

- discover product flaws prior to property evaluation studies

- determine homogeneity of the waste form product

- assess processing reproducibility

These tests, as described below, were performed on representative specimens throughout the process development phase of the program to provide quality assurance feedback on process controlled parameters. 


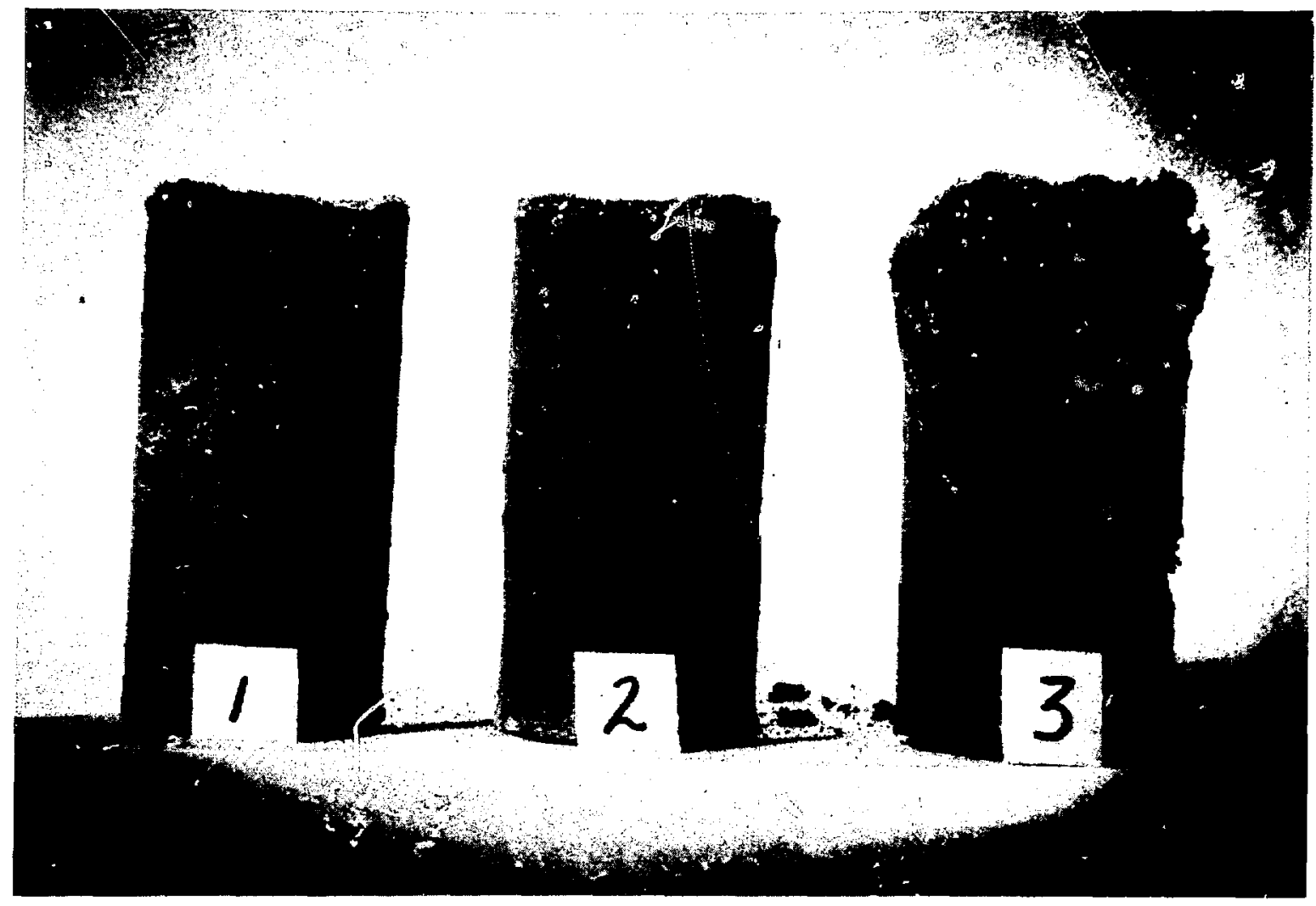

Figure 4.4 Modified Sulfur Cement Waste Forms Containing 35, 40 and 50 wt\% Boric Acid Waste (No. 1, 2, 3, respectively) Which Were Processed at $>169^{\circ} \mathrm{C}$. Surface Spaliling and Cracking Occurred Upon Exposure to Ambient Laboratory Humidity Conditions. 


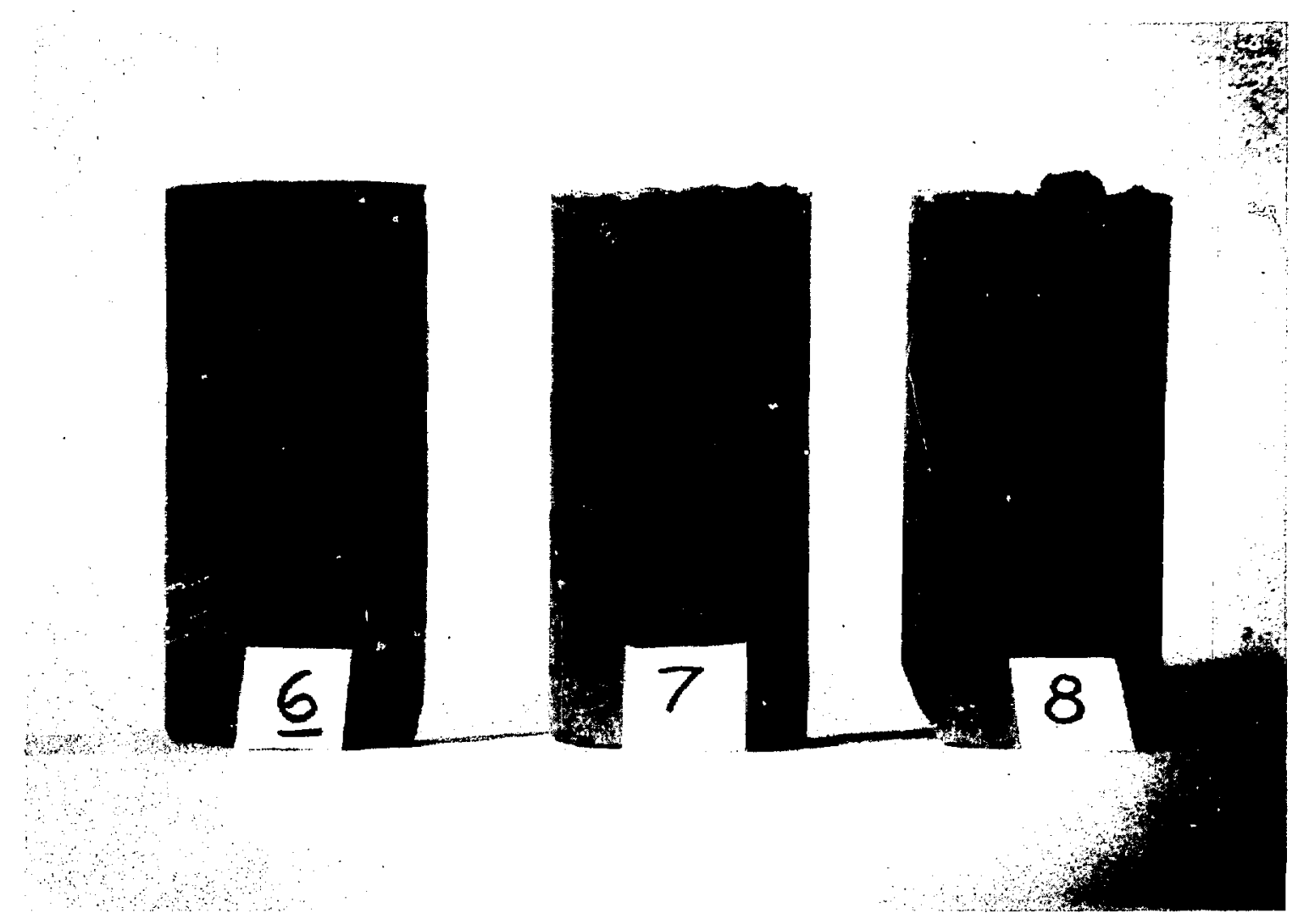

Figure 4.5 Modified Sulfur Cement Waste Forms Containing 20, 30 and 40 Wt\% Boric Acid Waste (No. 6,7 and 8, respectiveily) Processed at $121-122^{\circ} \mathrm{C}$. 
4.7.1 Detection of Voids. As discussed previously, modified sulfur cement tends to shrink along the axial centerline during cooling, leaving void cavities generally in the upper middle section of the waste form. Thus, the majority of voids are visible by inspecting the waste form's top surface. In addition, some waste form specimens were longitudinally cut to check for internal voids.

A typical void cavity can be seen in the photograph of a cross-sectioned modified sulfur cement specimen containing no waste (Figure 4.6). This tendency was reduced as increased waste loadings were introduced. Void formation was further mitigated by filling sample molds in several stages and allowing the mixture to cool and solidify between fillings.

4.7.2 Resistance to Spalling. Spalling and flaking of the waste form surface and in some cases severe degradation of mechanical integrity were observed for some specimens upon exposure to ambient air conditions within the laboratory (approximately $20^{\circ} \mathrm{C}, 25 \%$ relative humidity). This behavior is attributed to the sorption of atmospheric moisture by the waste. Solidified ion exchange resin specimens containing as little as $10 \mathrm{wt} \%$ waste displayed spalling as the dry resin beads took up moisture in the air and expanded. This phenomenon is readily observed in Figure 4.7 which compares the surface appearance of a specimen containing no waste with those containing $10,20,30$ and $40 \mathrm{wt} \%$ dry ion exchange resins after approximately 2 weeks exposure to ambient laboratory air. As discussed in Section 4.6.2, the formation of meta borate upon processing at temperatures greater than $169^{\circ} \mathrm{C}$ resulted in waste form products which were extremely hygroscopic. The deterioration of these specimens in air was shown in Figure 4.4 .

4.7.3 Waste Form Homogeneity. A thorough homogenization of waste within the solidified waste form is an important quality assurance parameter since it provides:

- Uniform distribution of radioactivity throughout the waste form-Avoidance of "hot" spots is an important consideration for the safe handling, storage and transportation of solidified LLW.

- Uniform physicochemical properties--Substantial variations in waste concentration throughtout the waste form can significantly alter such properties as leachability and compressive strength.

- Accuracy in waste loading determination--Since processing of modified sulfur cement is performed in batches yielding a number of separate waste forms, homogeneity must be assumed in determing the quantities of waste incorporated in each waste form.

As a measure of homogeneity, the waste form apparent density was calculated for a number of solidified waste formulations. Volume measurements were based on waste form dimensions. Results of apparent density calculations are presented in Table 4.3. These data are based on 8 repl icate specimens for each waste loading. Mean values, standard deviation around the mean, and absolute and relative error at the 95\% confidence interval are included. Figure 4.8 is a plot representing waste form apparent density vs. waste loading. 


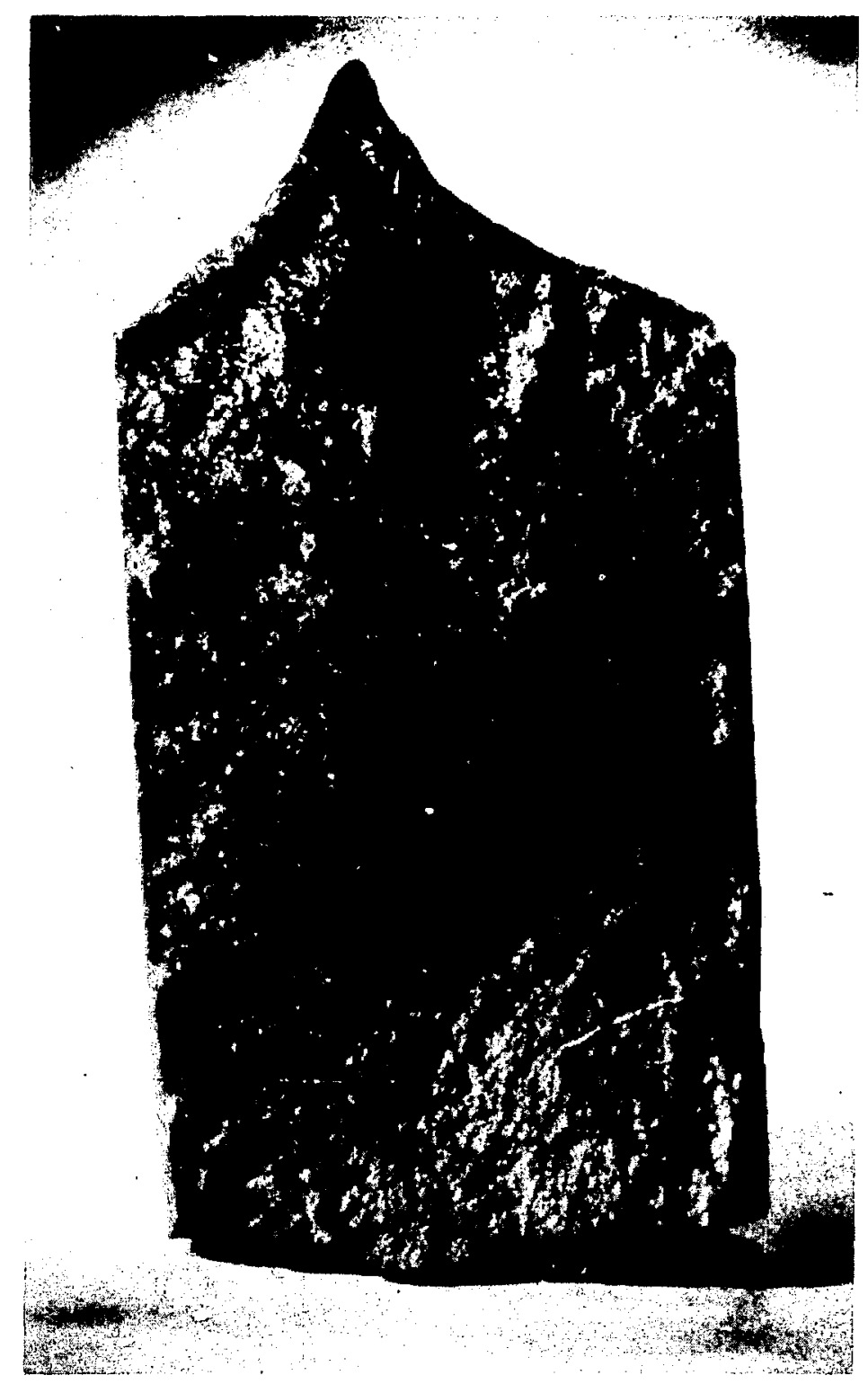

Figure 4.6 Cross-Sectional View of a Neat Modified Sulfur Cement Specimen, Displaying Void Cavity Formed Upon Cooling. 


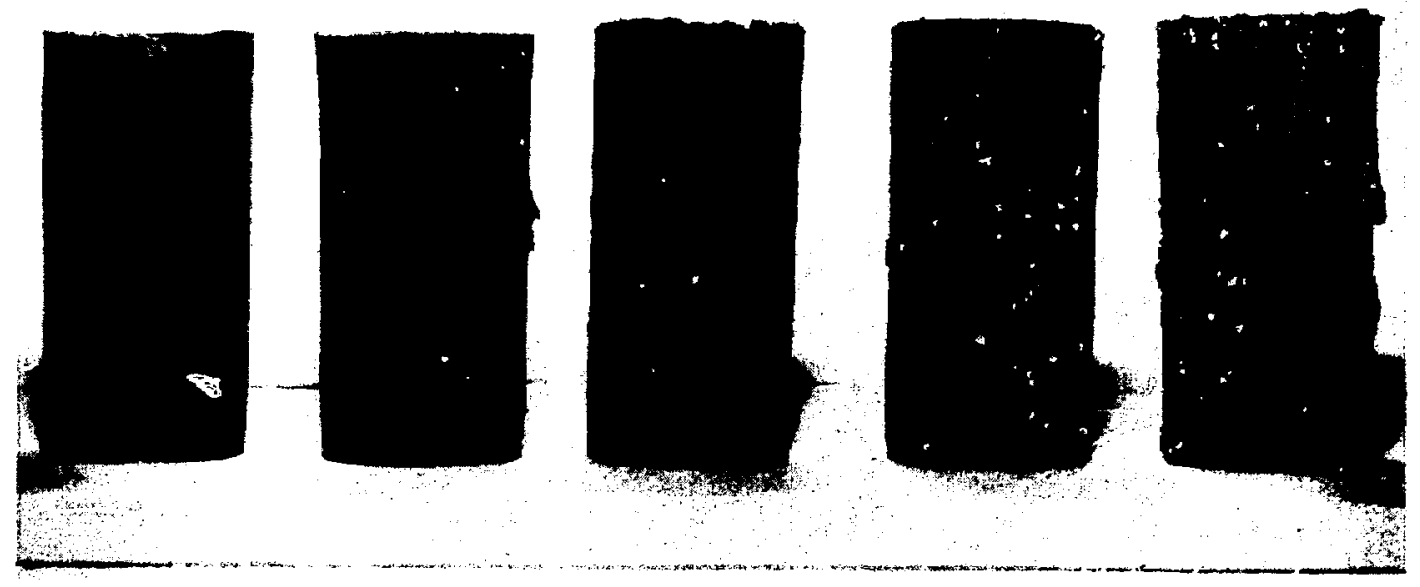

Figure 4.7 Modified Sulfur Cement Specimens Containing (From Left to Right), $0,10,20,30$ and $40 \mathrm{wt} \%$ Ion Exchange Resins, Upon Exposure to Ambient Laboratory Humidity Conditions. 
Table 4.3

Modified Sulfur Cement Waste Form Densities(a)

Waste

Type

Sodium Sulfate

Boric Acid

Incinerator Ash

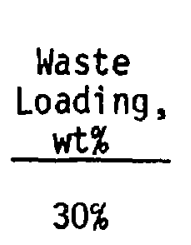

$40 \%$

$50 \%$

$20 \%$

$30 \%$

$40 \%$

$10 \%$

$20 \%$

$30 \%$

$40 \%$

Mean

Apparent

Density, (b) Standard $\mathrm{g} / \mathrm{CC}$

2.007

2.053

2.095

1.667

1.586

1.448

1.904

1.955

1.828

1.914

0.033

0.046

0.038

0.044

0.073

0.028

Absolute(c)

Error

0.014

0.061

0.032

0.046

0.028

0.034

2.4

2.0

2.2

4.0

1.5

a) Data based on 8 replicate specimens.

b) Calculated based on waste form dimensions.

c) Expressed at the 95\% confidence interval.

d) $\%$ Error $=$ Absolute Error/Mean. 


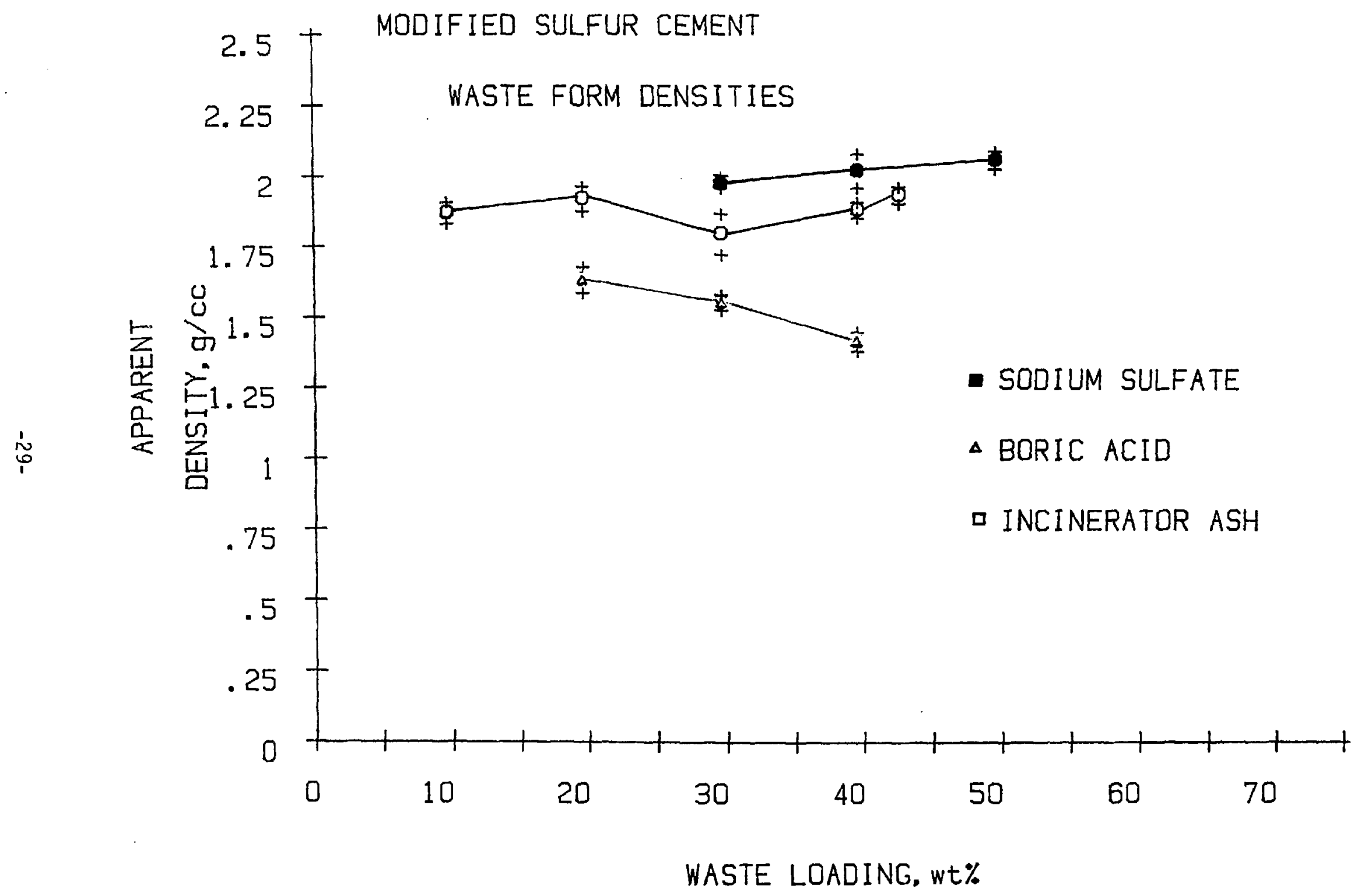

Figure 4.8 Modified Sulfur Cement Waste Form Apparent Density as a Function of Waste Loading. Data Represent the Mean for Three Replicates, Bracketed by Minimum and Maximum Values. 
In general, waste form densities within each batch were in close agreement, as evidenced by the small error around the mean (ranging from $0.7 \%$ to $4.0 \%)$. This is indicative of both good homogeneity within samples and good reproducibility in processing. For sodium sulfate, waste form densities increased with additional waste loadings. Since the bulk density of the waste (approximately $2.68 \mathrm{~g} / \mathrm{cm}^{3}$ ) is greater than that of the binder (approximately $\left.1.96 \mathrm{~g} / \mathrm{cm}^{3}\right)$, this effect is expected. Solidified boric acid waste form densities decreased with higher waste loadings. Similarly, as the bulk density of ortho boric acid (approximately $1.44 \mathrm{~g} / \mathrm{cm}^{3}$ ) is less than that of modified sulfur cement, this behavior is anticipated.

Based on its extremely low bulk density (approximately $0.23 \mathrm{~g} / \mathrm{cm}^{3}$ ), one would also expect an inversely proportional relationship between waste loading and density for incinerator ash waste forms. Instead, apparent density measurements ranged between 1.828 and $1.968 \mathrm{~g} / \mathrm{cm}^{3}$ without correlation to the quantity of waste incorporated. This is due to the fact that the ash density increases dramatically upon wetting, so that the ash and molten sulfur densities are roughly equivalent. 


\section{WASTE FORM PROPERTY EVALUATION STUDIES}

\subsection{Introduction}

The primary objective of any disposal system is the isolation of contained radionuclides from the environment until such time has elapsed that activities have decayed to safe levels. For most radionuclides contained in LLW, approximately 300 years of containment is sufficient. In recent years both commercial and DOE defense-related LLW disposal operations have come under increased scrutiny. Activity releases due to performance failures such as trench cap subsidence have been recorded at some sites. Maintaining the waste in a stable manner over time, e.g. by solidification, is one means of assuming the successful long-term performance of LLW disposal sites.

Prediction of actual waste form behavior in the disposal environment over long periods of time is a difficult, if not impossible task. Interactions between the waste form and environment are compounded by the synergistic effects of waste-binder interactions. However, the performance of a number of laboratory scale property evaluation tests can provide valuable information on potential waste form behavior and can provide a basis for comparison of various waste-binder formulations. Thus, a physicochemical data base of relevant modified sulfur cement waste form properties has been developed for comparison with other binder materials. These data were generated through the application of a number of standardized property tests for simulated laboratory scale waste forms, based upon preliminary evaluation criteria as reported in the Letter Report to DOE25. These tests include:

- Compressive Strength (ASTM C-39)

- Water Immersion (90 days, ASTM C-39)

- Thermal Cycling (ASTM D-621, C-39)

- Leaching (ANS 16.1, 90 days)

The tests listed above are also included in NRC's Branch Technical Position on Waste Form 26 , so that results may be readily compared with waste forms tested for compliance with 10 CFR 61 stability requirements 13 . It is not the intention of this program however, to qualify waste forms for commercial disposal. Additional testing (including biological and radiation stability tests) which were beyond the scope of this investigation would be required for NRC approval.

Waste form testing as outlined above was conducted for modified sulfur cement waste forms containing a range of waste loadings for each waste type investigated. In some cases testing of certain waste-binder formulations was omitted based on the poor performance of those formulations in previous scoping tests. Waste form testing procedures and results are presented in this section. 


\subsection{Compressive Strength}

Waste form compressive strength is used as both a general indicator of mechanical integrity and a specific measure of the waste form's ability to withstand loading pressures arising from overburden in the disposal setting. Modified sulfur cement is a relatively brittle material and tends to fail by a shattering fracture under axial compressive loads (see Figure 5.4). Compressive strength testing was therefore performed in accordance with the standard method developed for hydraulic cements, ASTM C-39, "Compressive Strength of Cylindrical Concrete Specimens"27.

Three replicate cylindrical test specimens nominally measuring $4.7 \mathrm{~cm}$ in diameter by $10.0 \mathrm{~cm}$ in height $(1.9 \times 3.9$ inches) were prepared for each waste formulation tested. Both ends of each specimen were capped to provide smooth surfaces, perpendicular to the axial centerline. Testing was performed using a Model AP-1000 Versatester, manufactured by Soiltest, Evanston, IL, as pictured in Figure 5.1 .

Compression testing results for modified sulfur cement waste forms containing sodium sulfate, boric acid and incinerator ash are presented in Table 5.1. Ion exchange resin samples were not tested due to poor performance in other testing, as discussed in Sections 4.7 and 5.3. Mean compressive strength and standard deviation are presented for the three replicates in units of psi and $\mathrm{MPa}$. The data are represented graphically as a function of waste loading in Figure 5.2 for the dry salt wastes, and Figure 5.3 for incinerator ash. The error bars in these plots depict the data spread around the average values. In some cases these error bars are unexpectedly wide, possibly due to internal voids within the specimens, or inhomogeneities within the waste and/or waste forms.

The compressive strength of modified sulfur cement samples containing no waste was approximately 1800 psi. Virtually all test specimens incorporating simulated waste displayed greater compressive strengths. The addition of waste solids acts as an aggregate which, together with the matrix form a material of increased strength. Boric acid provided the least improvement in compressive strength while the addition of incinerator ash provided the greatest gains. For sodium sulfate, increasing waste loadings between 30 and $50 \mathrm{wt} \%$ provided improvement in compressive strength results. A slight decrease in the compressive strength of boric acid specimens with increased waste loading was observed. This may be related to density reduction, but the magnitude of these variations was too small to be conclusive. For incinerator ash waste forms however, the relationship between waste loading and waste form compressive strength appears erratic. These apparent discrepencies may be due to the presence of voids within specimens, variations in the homogeneity of the waste, or scatter associated with the number of specimens tested. Figure 5.4 depicts ash compression specimens before and after testing, revealing the presence of small voids. In any case, all specimens tested easily surpassed the current minimum compressive strength of 50 psi as specified by the NRC in their Branch Technical Position. 


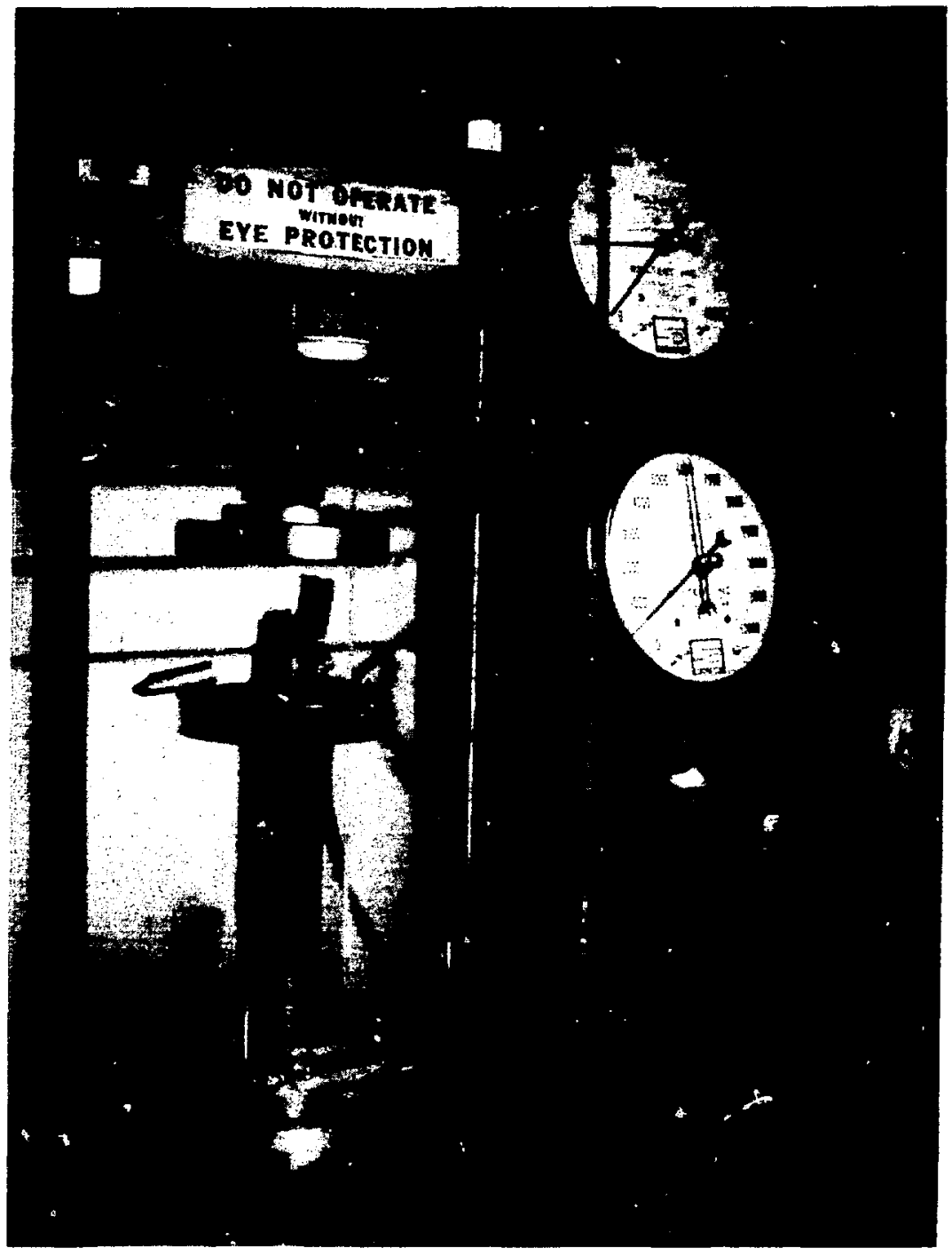

Figure 5.1 Modified Sulfur Cement Waste Form Test Specimen Undergoing Compressive Strength Test. 


\section{Table 5.1}

Modified Sulfur Cement Waste Form Compressive Strength Results(a), (b)

\begin{tabular}{|c|c|c|c|c|}
\hline $\begin{array}{l}\text { Waste } \\
\text { Iype }\end{array}$ & $\begin{array}{l}\text { Waste } \\
\text { Loading, } \\
\text { wt\% } \\
\end{array}$ & $\begin{array}{l}\text { Compressive } \\
\text { Strength, } \\
\text { psi } \\
\end{array}$ & $\begin{array}{l}\text { Standard } \\
\text { Deviation, } \\
\text { psi }\end{array}$ & $\begin{array}{c}\text { Compressive } \\
\text { Strength, } \\
\mathrm{MPa} \\
\end{array}$ \\
\hline $\operatorname{Neat}(c)$ & $0 \%$ & 1822 & 180 & 12.6 \\
\hline \multirow[t]{3}{*}{ Sodium Sulfate } & $30 \%$ & 3663 & 533 & 25.3 \\
\hline & $40 \%$ & 4356 & 60 & 30.0 \\
\hline & $50 \%$ & 4564 & 236 & 31.5 \\
\hline \multirow[t]{3}{*}{ Boric Acid } & $20 \%$ & 2152 & 123 & 14.8 \\
\hline & $30 \%$ & 2002 & 156 & 13.8 \\
\hline & $40 \%$ & 1998 & 136 & 13.8 \\
\hline \multirow[t]{5}{*}{ Incinerator Ash } & $10 \%$ & 5371 & 310 & 37.0 \\
\hline & $20 \%$ & 4317 & 304 & 29.8 \\
\hline & $30 \%$ & 4251 & 2112 & 29.3 \\
\hline & $40 \%$ & 6435 & 129 & 44.4 \\
\hline & $43 \%$ & 4434 & 255 & 30.6 \\
\hline
\end{tabular}

a) Performed in accordance with ASTM C-39.

b) Results ruflect mean values for 3 replicate specimens.

c) Results reflect mean values for 5 replicate specimens. 


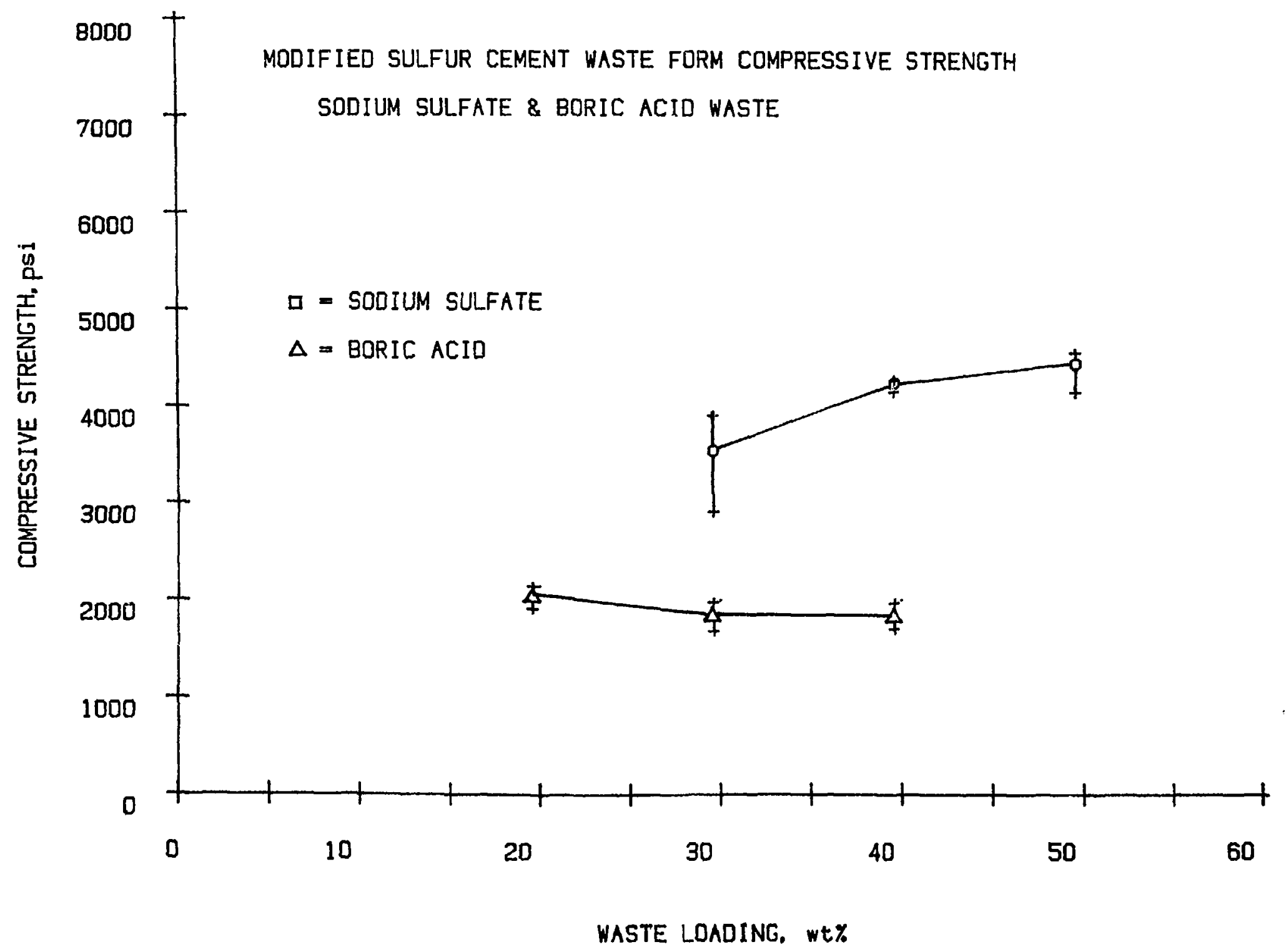

Figure 5.2 Compressive Strength as a Function of Waste Loading for Modified Sulfur Cement Waste Forms Containing Sodium Sulfate and Boric Acid Wastes. Data Points Represent the Mean, and Error Bars the Range of Measured Values. 


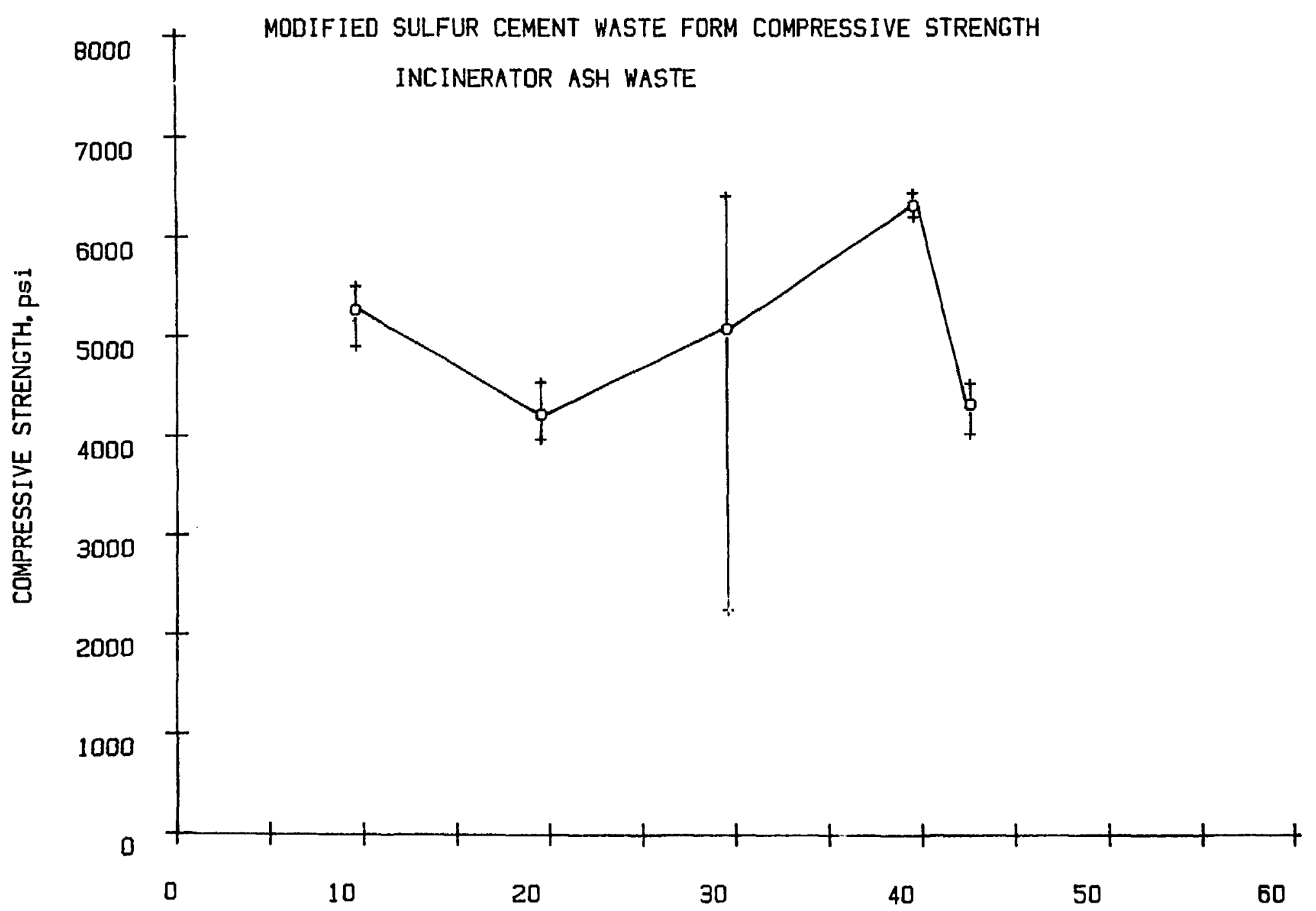

WASTE LOADING, wt\%

Figure 5.3 Compressive Strength as a Function of Waste Loading for Modified Sulfur Cement Waste Forms Containing Incinerator Ash Waste. Data Points Represent the Mean, and Error Bars the Range of Measured Values. 

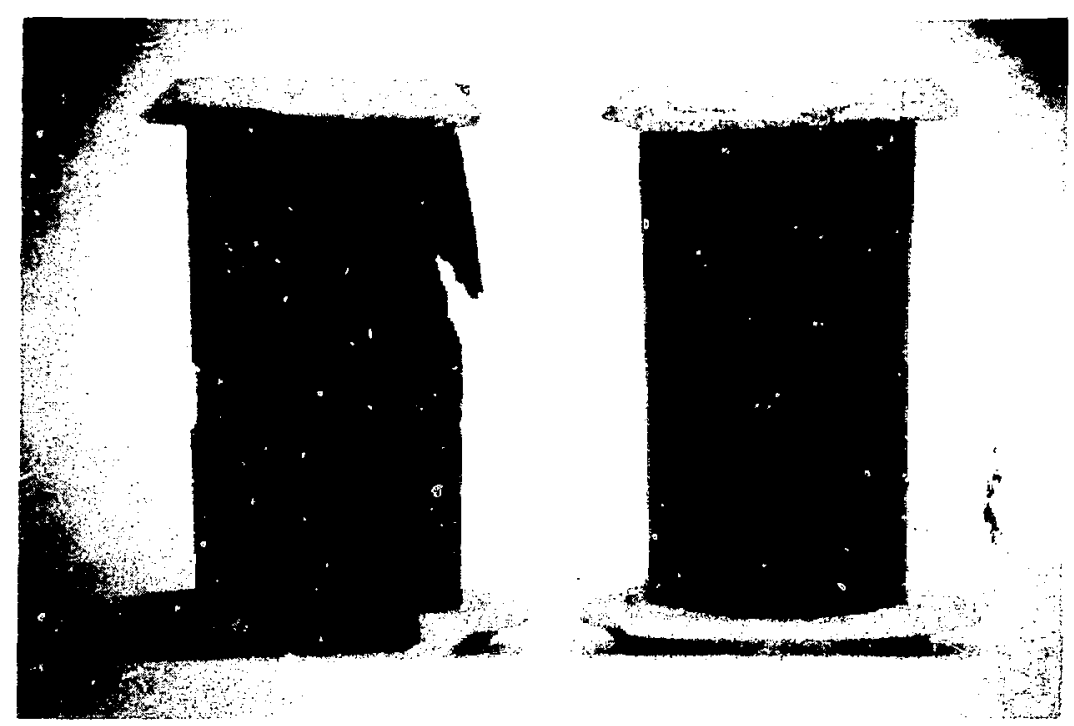

Figue 5.4 Modified Sulfur Cement Waste Form Specimens Containing 30 Wt\% Incinerator Ash Before Testing (Right) and After Testing (Left). 


\subsection{Water Immersion}

Processing temperatures for modified sulfur cement result in dehydration of aqueous wastes and encapsulation of the dry solids residue within the waste form occurs upon cooling. The waste is then susceptible to rehydration reactions upon contact with water, which can cause swelling and disturb the structure of the waste form. In order to simulate exposure of waste forms to an aqueous environment, test specimens were immersed in water for 90 days.

Water immersion testing was performed on two replicate specimens for each waste loading formulation. Formulations, loadings and dimensions correspond to those prepared for compressive strength measurements as described in Section 5.2. Each specimen was completely immersed in demineralized water at ambient temperature $\left(20^{\circ} \mathrm{C}\right)$ and was examined periodically. Upon completion of 90 days, they were removed from the water and checked for variations in weight and dimension. Compression testing was then conducted according to ASTM C-39 and results are summarized in Table 5.2.

As previously discussed, all specimens containing ion exchange resins failed catastrophically in water immersion. Dry resin beads readily sorb water and expand, resulting in cracking and disintegration of waste forms. Ion exchange resin waste form failures occurred rapidiy as demonstrated by the photographs in Figure 5.5, which depict deterioration of a modified sulfur cement waste form containing 10 wt\% resin within 5 minutes. Complete structural failure for this specimen occurred in less than one day.

Specimens containing 80 wt\% sodium sulfate and 57 wt\% boric acid suffered severe cracking within several days. Sodium sulfate waste forms containing 50 wt\% waste developed visible cracks after approximately 48 days in immersion. These specimens are shown in the photograph in Figure 5.6 taken after 65 days in immersion. The minor cracks shown in Figure 5.6 significantly expanded and degraded the samples during the remainder of the 90 day test period. In contrast, waste forms containing $40 \mathrm{wt} \%$ sodium sulfate show no signs of cracking after 65 days in immersion as seen in Figure 5.7

Waste forms which did not fail, i.e. crack, as a result of water immersion experienced negligible weight loss and changes in dimensions. With the exception of 3 formulations ( 20 and $30 \mathrm{wt} \%$ boric acid and $43 \mathrm{wt} \%$ ash), 1 osses in compressive strength between 8 and $46 \%$ were recorded. Improvements in compressive strength are attributed to experimental scatter associated with the limited sample population. Sufficient strength was retained by all modified sulfur cement waste forms tested under compression to meet storage, transportation and disposal requirements. A graphical comparison with non-water immersion compression data is presented in the histogram in Figure 5.8 .

\subsection{Thermal Cycling}

In some cases during transportation and storage operations, waste forms may be subjected to severe changes in temperature. Since unmodified sulfur cement is subject to deterioration upon thermal shocking, waste fom behavior under these conditions was investigated. Testing was conducted by conditioning the waste forms in accordance with the procedures outlined in ASTM B-553, "Thermal Cycling of Electroplated Plastics," 28 with modifications, as recommended by the NRC26. Changes in physical properties were then examined by means of compressive strength testing. 
Table 5.2

Modified Sulfur Cement Waste Form Compressiye Strength Upon
Completion of Water Immersion Test $(a),(b)$

\begin{tabular}{|c|c|c|c|c|}
\hline $\begin{array}{l}\text { Waste } \\
\text { Type }\end{array}$ & $\begin{array}{c}\text { Waste } \\
\text { Loading, wt\% }\end{array}$ & $\begin{array}{l}\text { Compressive } \\
\text { Strength, psi }\end{array}$ & $\begin{array}{l}\text { Compressive } \\
\text { Strength, MPa }\end{array}$ & $\begin{array}{l}\text { Percent } \\
\text { Change in } \\
\text { Strength(c) }\end{array}$ \\
\hline \multirow[t]{4}{*}{ Sodium Sulfate } & $30 \%$ & 2482 & 17.1 & $-32 \%$ \\
\hline & $40 \%$ & 2985 & 20.6 & $-31 \%$ \\
\hline & $50 \%$ & $N A(d)$ & NA & NA \\
\hline & $80 \%$ & NA & NA & NA \\
\hline \multirow[t]{4}{*}{ Boric Acid } & $20 \%$ & 3112 & 21.5 & $+44 \%$ \\
\hline & $30 \%$ & 2600 & 17.9 & $+30 \%$ \\
\hline & $40 \%$ & 1347 & 9.3 & $-41 \%$ \\
\hline & $57 \%$ & $\operatorname{NA}(d)$ & NA & NA \\
\hline \multirow[t]{5}{*}{ Incinerator Ash } & $10 \%$ & 2905 & 20.0 & $-46 \%$ \\
\hline & $20 \%$ & 3991 & 27.5 & $-8 \%$ \\
\hline & $30 \%$ & 3870 & 26.7 & $-9 \%$ \\
\hline & $40 \%$ & 4090 & 28.2 & $-36 \%$ \\
\hline & $43 \%$ & 5396 & 37.2 & $+22 \%$ \\
\hline
\end{tabular}

a) Two replicate specimens immersed in water for 90 days.

b) Compression testing performed in accordance with ASTM C-39.

c) Comparison with non-water immersion specimen data as presented in Table 5.1

d) Not available; samples failed in immersion. 

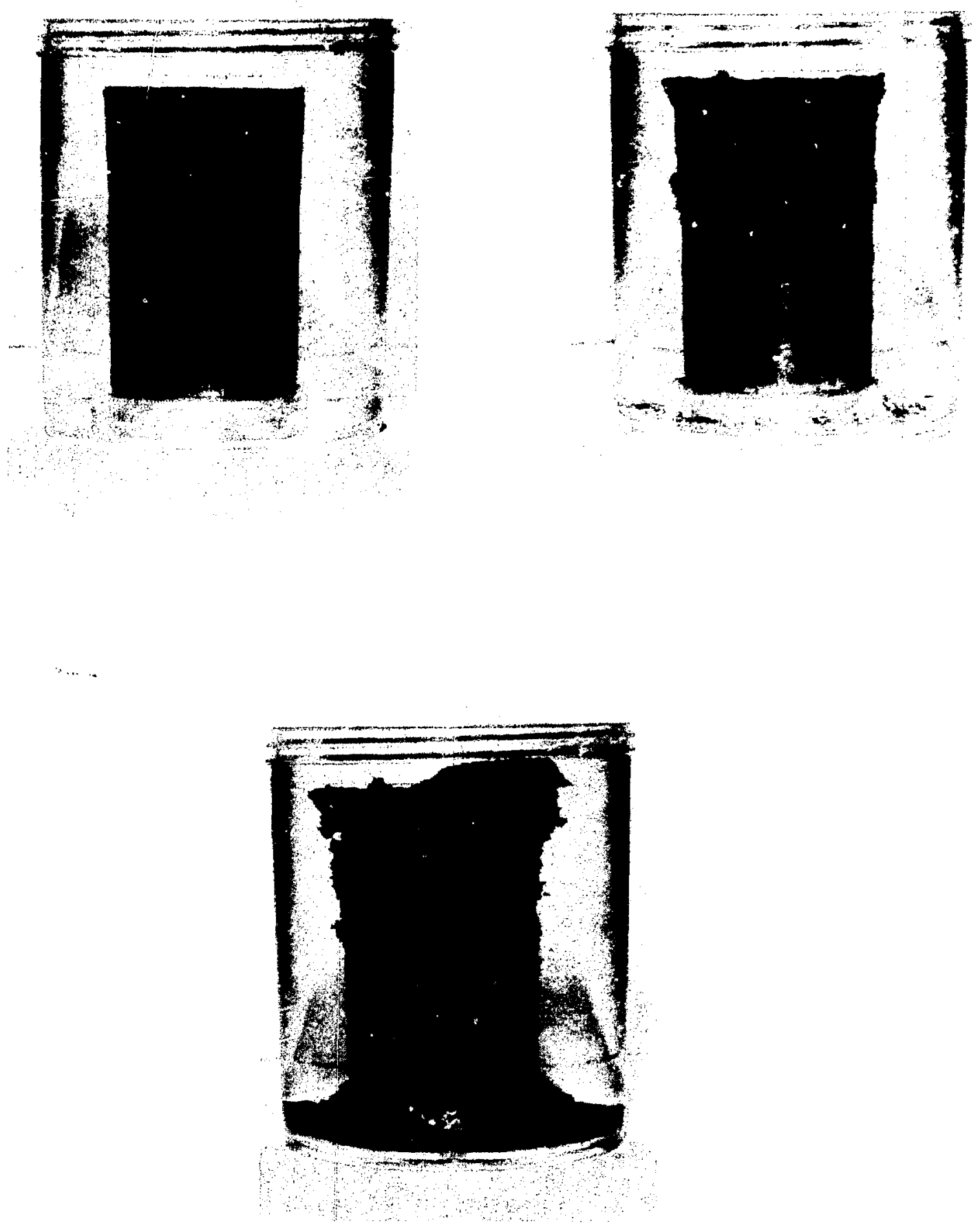

Figure 5.5 Modified Sulfur Cement Waste Form Incorporating 10 Wt\% Dry Ion Exchange Resin While Undergoing a Water Immersion Test. All Three Photographs are of the Same Sample, Taken Within Five Minutes of the Initiation of the Test. Complete Structural Failure of the Sample was Observed in Less Than one Day. 


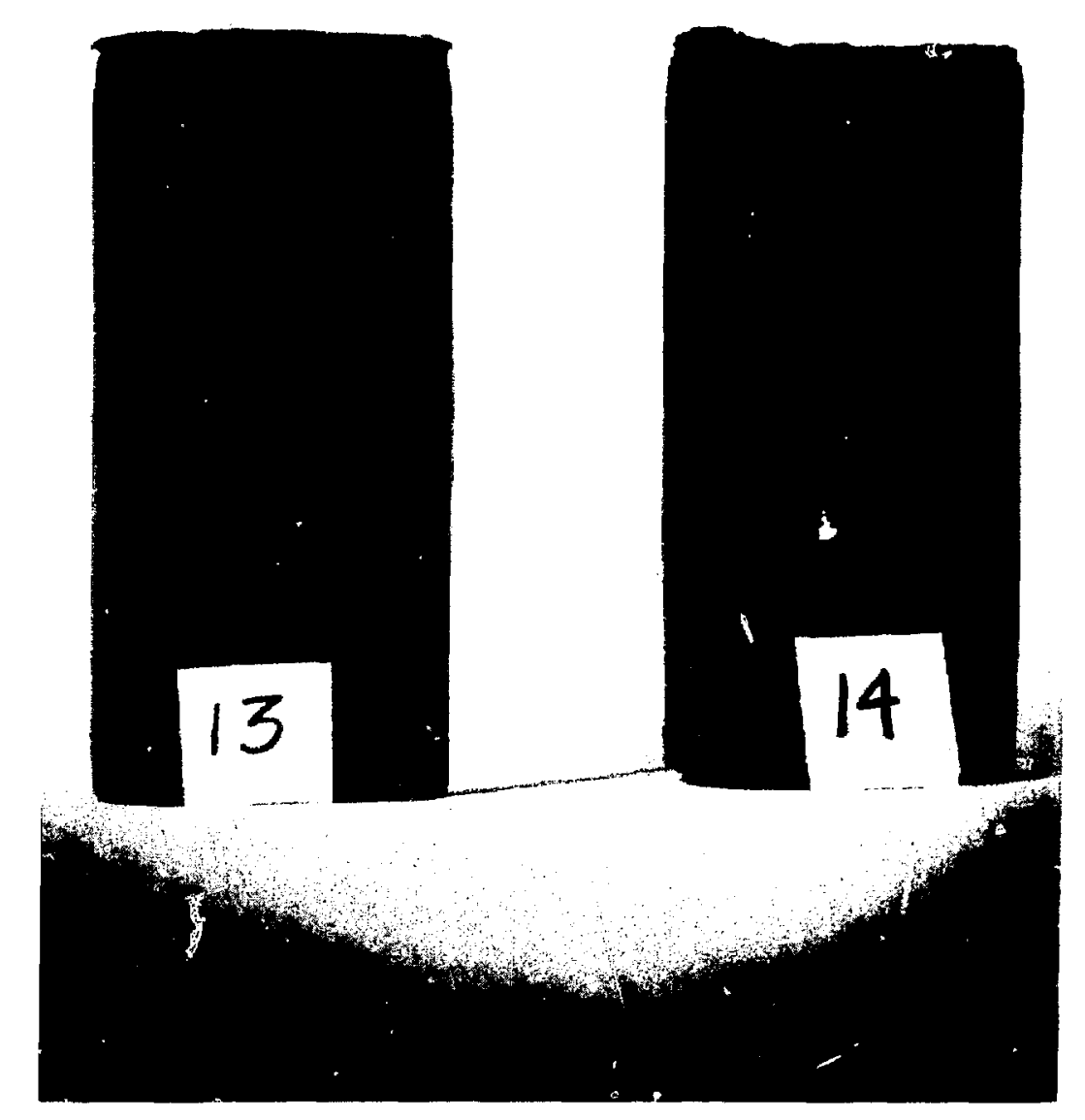

Figure 5.6 Modified Sulfur Cement Waste Forms Containing 50 Wt\% Sodium Sulfate Showing Crack Formation After 65 Days in Water Immersion. Further Degradation Dccurred During the Remainder of the 90 Day Water Immersion Test. 


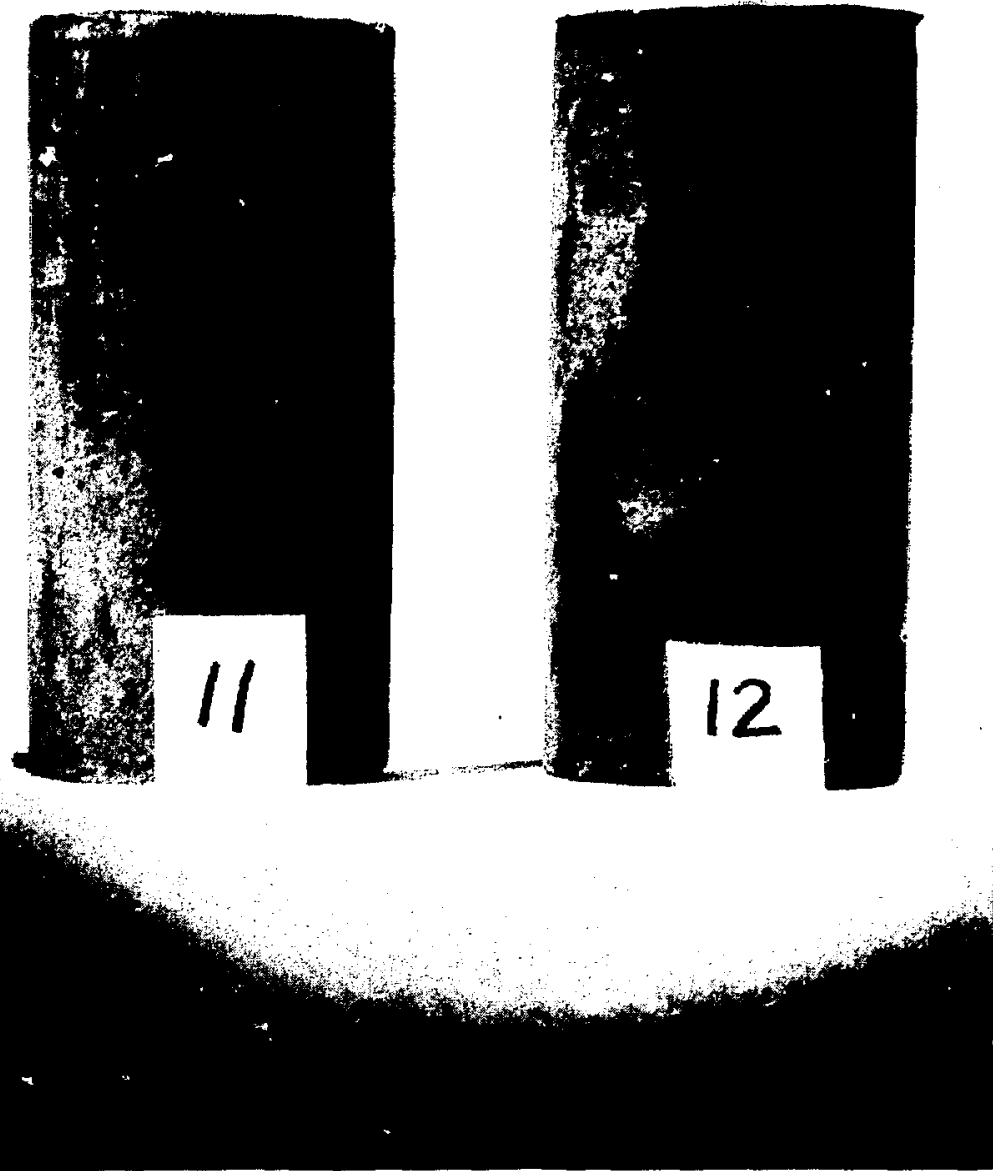

Figure 5.7 Modified Sulfur Cement Waste Forms Containing 40 wt\% Sodium Sulfate Shown After 65 Days in Water Immersion. Upon Completion of the 90 Day Water Immersion Test no Cracking was observed. 


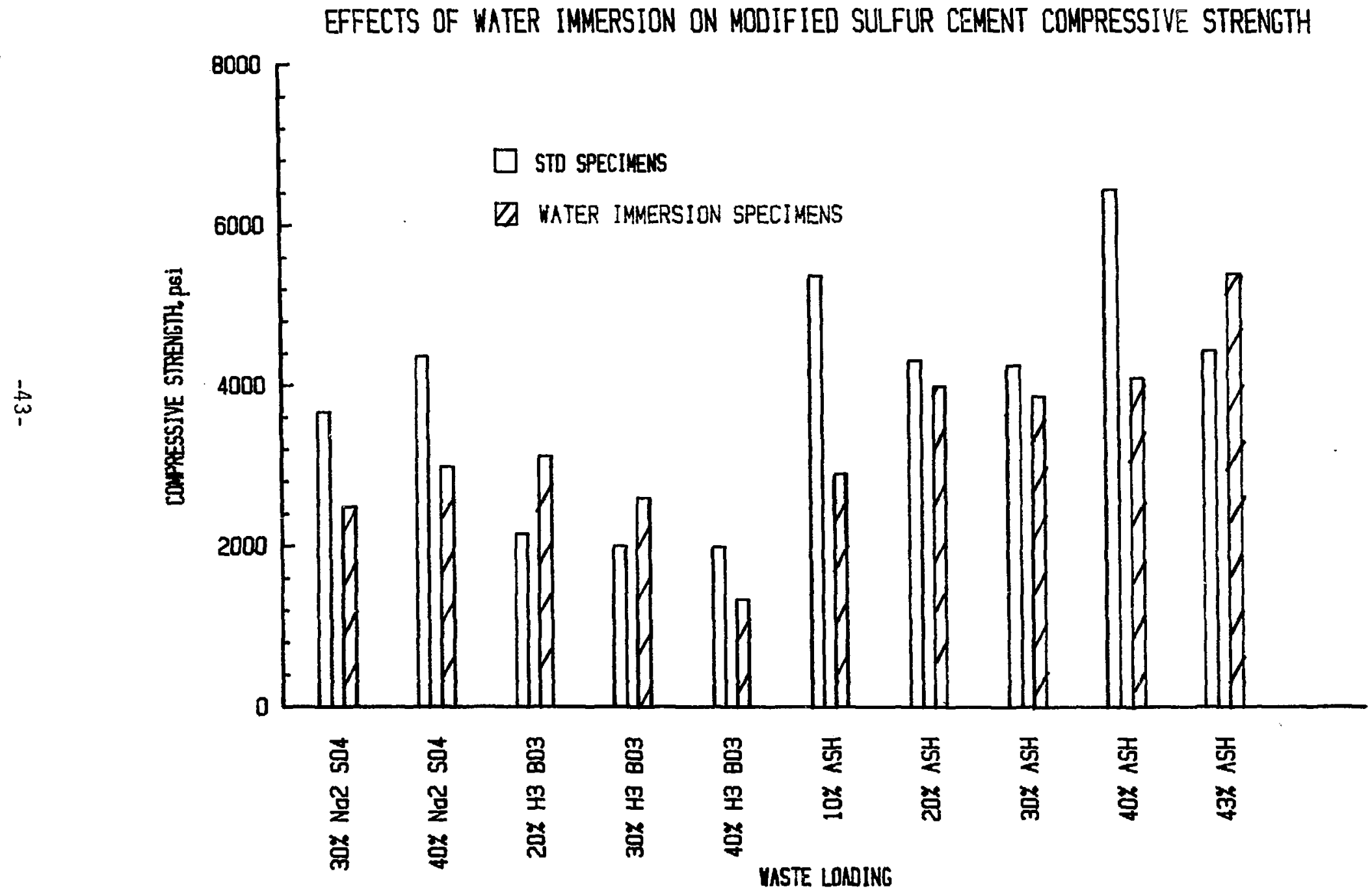

Figure 5.8 Histogram Comparing Results of Compressive Strength Measurements for Standard and Water Immersion Specimens. 
Cycling of waste form specimens was performed using a Model T6C environmental chamber, manufactured by Tenney Engineering, Inc., Union, NJ. The chamber, as pictured in Figure 5.9 has a capacity of 6 cubic feet. It is capable of achieving temperature ranges between $-73^{\circ} \mathrm{C}$ and $+200^{\circ} \mathrm{C}$, with a control tolerance of $\pm 0.3^{\circ} \mathrm{C}$. Temperature settings and duration are microprocessor controlled. Heating and cooling functions are maintained by conditioned air flow.

Waste form specimens tested were replicates of those employed for compressive strength testing. As such, their dimensions measured a nominal 4.7 $\mathrm{cm}$ ( 1.9 inches) in diameter by $10.0 \mathrm{~cm}(3.9$ inches) in height. Three replicate specimens for each waste-binder combination were placed in the chamber and cycled between $+60^{\circ} \mathrm{C}$ and $-40^{\circ} \mathrm{C}$ for a total of 30 cycles in accordance with NRC recommendations. Temperatures were held at each extreme for a period of one hour, separated by one hour at $20^{\circ} \mathrm{C}$. Temperature ramp times varied between 8 minutes $\left(20^{\circ} \mathrm{C}\right.$ to $\left.60^{\circ} \mathrm{C}\right)$ and 15 minutes $\left(20^{\circ} \mathrm{C}\right.$ to $\left.-40^{\circ} \mathrm{C}\right)$. The total time required to complete one cycle was approximately 5 hours as seen in Figure 5.10 which represents a graphical representation of cycling conditions. Chamber temperatures were recorded by a 24 hour circular chart recorder. In addition, representative specimens were monitored by thermocouples to verify uniform temperatures throughout the chamber and to track their repsonse to changes in chamber temperatures.

Specimens were removed from the chamber upon completion of themal cycling and examined. No changes in physical dimensions or structure were observed. Compressive strength testing was then conducted as described in Section 5.2. Results are reported in Table 5.3. As a graphical means of comparison with results from non-thermal cycled specimens these data are plotted in Figure 5.11 where they are shown by the shaded bars in the histogram.

Moderate reductions in compressive strength $(\leq 23 \%)$ were recorded for thermally cycled sodium sulfate waste forms. Bor $\frac{1 c}{2}$ acid waste form specimens actually increased in compressive strength by as much as $69 \%$ after thermal cycling. Data for incinerator ash waste forms show no clear trends in compressive strength as a result of thermal cycling. In general, thermal effects were minor for modified sulfur cement and should not impose any limitations on its use as a potential radwaste binder.

\subsection{Leaching}

The retention of radionuclides within the disposal environment is dependent upon several factors, but the initial barrier to activity release is the waste form itself. Although laboratory leaching methods do not realistically simulate burial site conditions, the use of a standardized leach test methodology enables a comparative assessment of leachability for a given waste-binder combination.

5.5.1 Methodology. With this goal in mind, leach testing for modified sulfur cement waste forms was conducted in accordance with the ANS 16.1 Standard "Measurement of the Leachability of Solidified Low-Level Radioactive Wastes." 29 Since this method was selected by the NRC for demonstration of waste form stability as set forth in 10 CFR 61, the leaching data base for various binder materials generated under 16.1 protocol, is growing. 


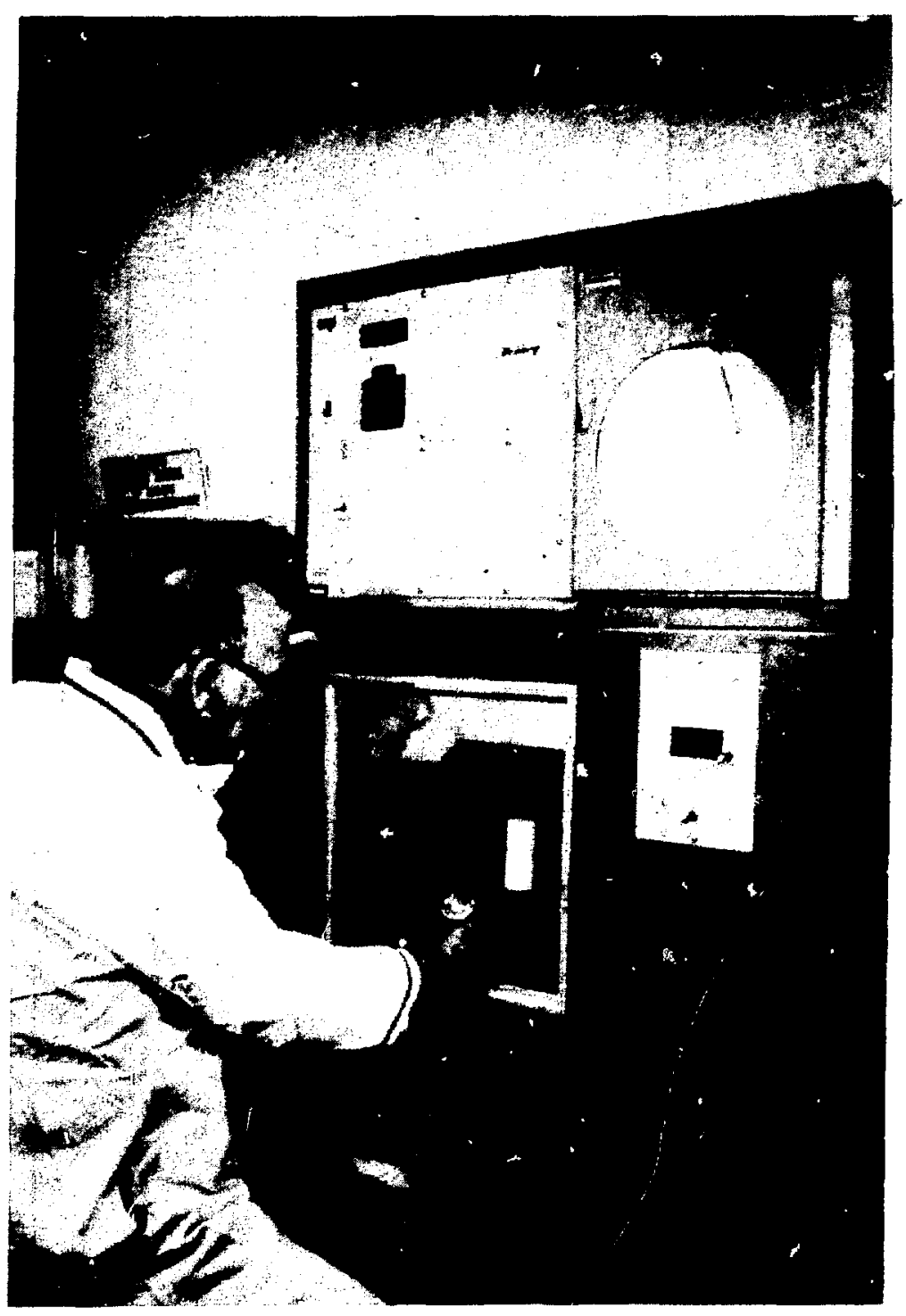

Figure 5.9 Photograph of Microprocessor Controlled Thermal Cycle Environmental Chamber for Conditioning Specimens According to ASTM B-553. 


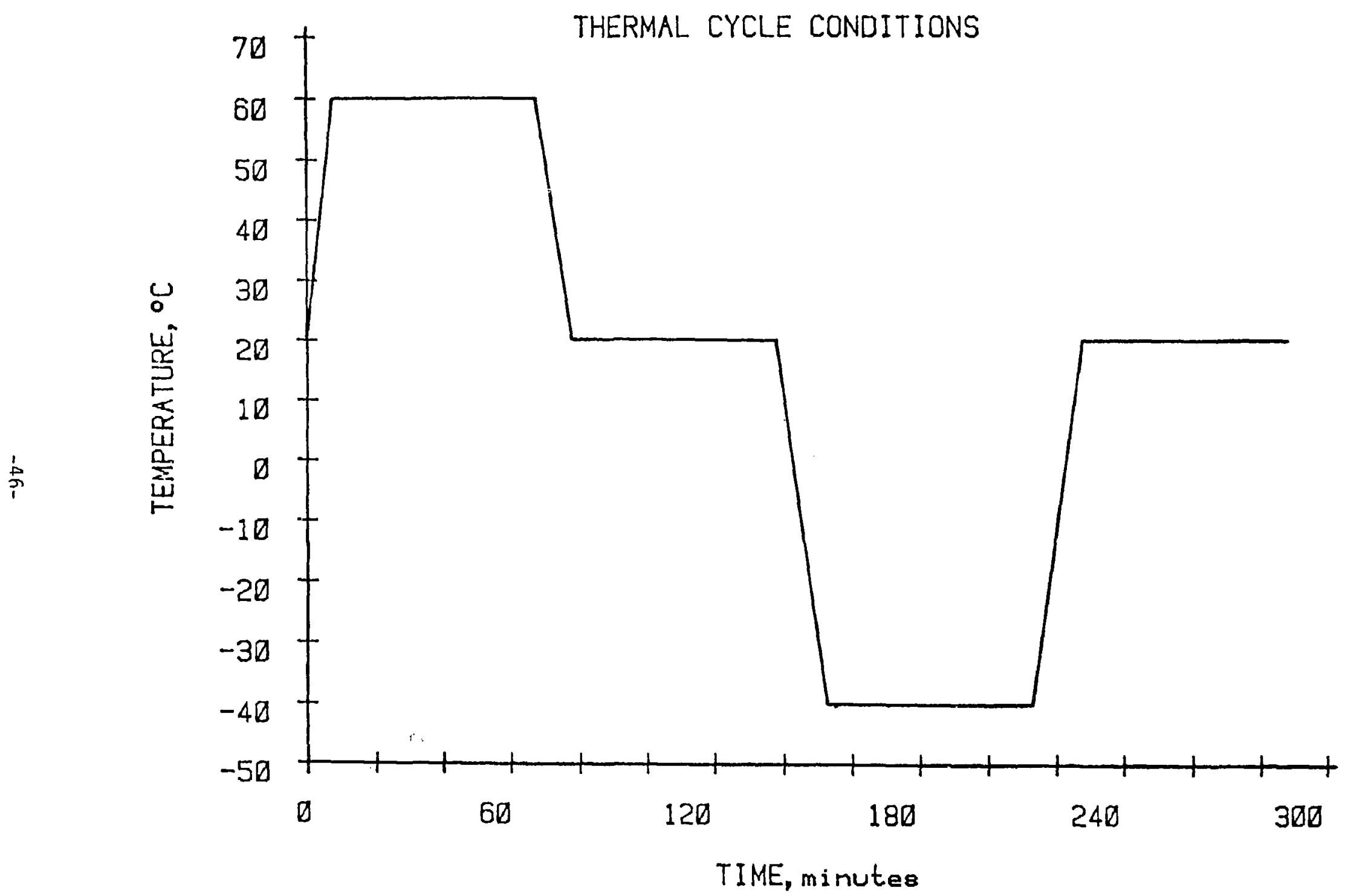

Figure 5.10 Graphical Representation of Temperature Conditions and Duration for One Thermal Cycle. 
Table 5.3

Modified Sulfur Cement Waste Form Compressive Strength for Thermal Cycled Specimens (a), (b), (c)

\begin{tabular}{|c|c|c|c|c|c|}
\hline $\begin{array}{l}\text { Waste } \\
\text { Type } \\
\end{array}$ & $\begin{array}{c}\begin{array}{c}\text { Waste } \\
\text { Loading, } \\
\text { wt\% }\end{array} \\
\end{array}$ & $\begin{array}{l}\text { Compressive } \\
\text { Strength, } \\
\text { psi }\end{array}$ & $\begin{array}{l}\text { Standard } \\
\text { Deviation, } \\
\text { psi } \\
\end{array}$ & $\begin{array}{c}\text { Compressive } \\
\text { Strength, } \\
\mathrm{MPa} \\
\end{array}$ & $\begin{array}{l}\text { Percent } \\
\text { Change in } \\
\text { Strength (d) }\end{array}$ \\
\hline \multirow[t]{3}{*}{ Sodium Sulfate } & $30 \%$ & 2797 & 1044 & 19.3 & $-24 \%$ \\
\hline & $40 \%$ & 3617 & 613 & 24.9 & $-17 \%$ \\
\hline & $50 \%$ & 3672 & 1198 & 25.3 & $-20 \%$ \\
\hline \multirow[t]{3}{*}{ Boric Acid } & $20 \%$ & 2214 & 1208 & 15.3 & $+3 \%$ \\
\hline & $30 \%$ & 3382 & 374 & 23.3 & $+69 \%$ \\
\hline & $40 \%$ & 2197 & 183 & 15.1 & $+10 \%$ \\
\hline \multirow[t]{5}{*}{ Incinerator Ash } & $10 \%$ & 4057 & 1049 & 28.0 & $-25 \%$ \\
\hline & $20 \%$ & 4366 & 929 & 30.1 & $+1 . \%$ \\
\hline & $30 \%$ & 3826 & 1717 & 26.4 & $-10 \%$ \\
\hline & $40 \%$ & 4739 & 948 & 32.7 & $-26 \%$ \\
\hline & $43 \%$ & 5336 & 2870 & 36.8 & $+20 \%$ \\
\hline
\end{tabular}

\footnotetext{
a) Thermal cycling performed in accordance with ASTM B-553 (see text).

b) Compression testing performed in accordance with ASTM C-39

c) Results reflect mean values for 3 replicate specimens.

d) Comparison with non-thermal cycled specimens as presented in Table 5.1.
} 


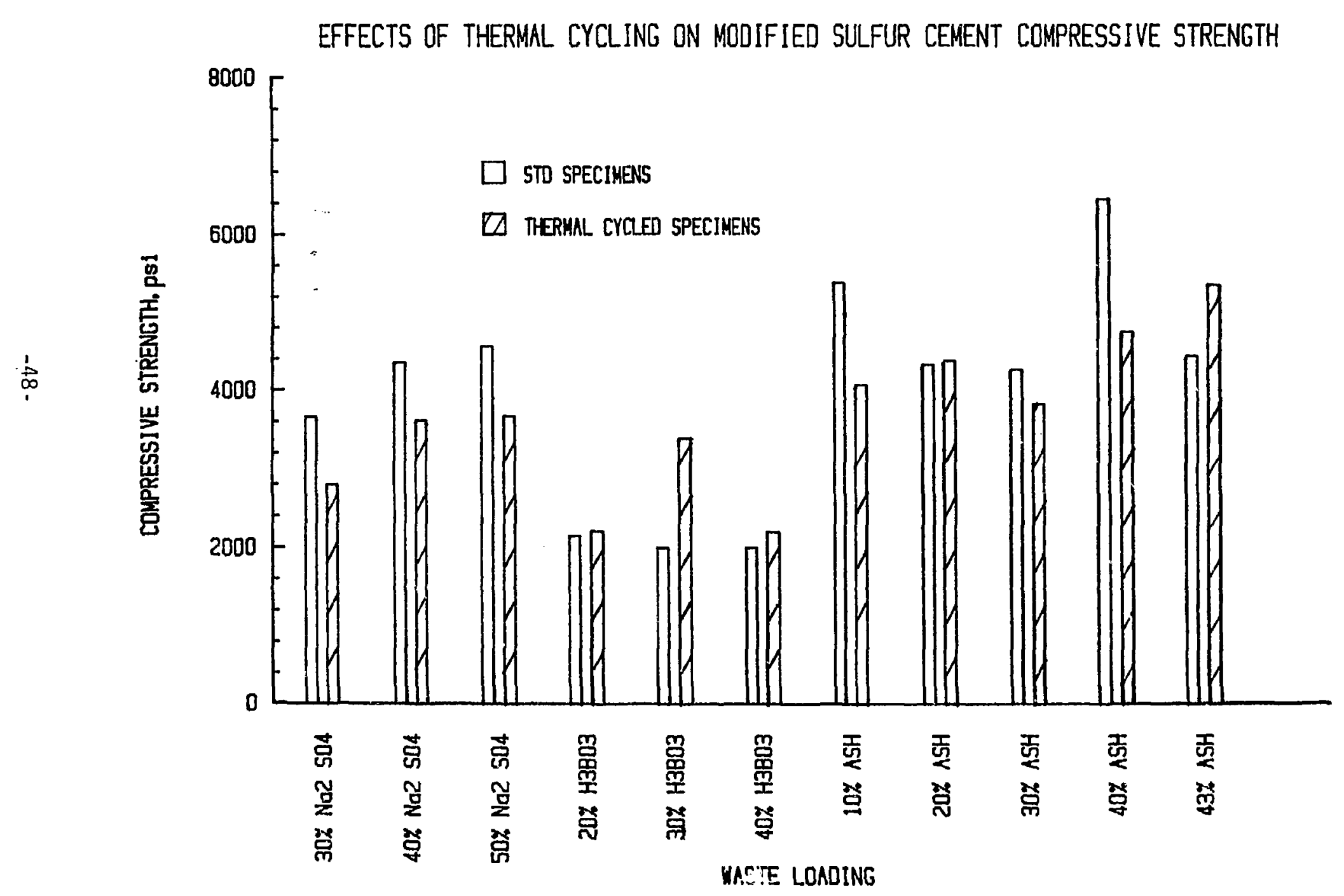

Figure 5.11 Histogram Comparing Compressive Strength for Standard and Thermal Cycled Specimens. 
5.5.2 Sample Preparation. Simulated radioactive waste forms were prepared in dupticate containing 25 and $40 \mathrm{wt} \%$ sodium sulfate and 20 and 40 wt\% incinerator ash. ${ }^{137} \mathrm{Cs}$ and $60 \mathrm{Co}$ tracers were added at a nominally constant ratio of $0.25 \mu \mathrm{Ci}$ per gram of waste. Activity concentrations found in actual low-level waste may vary over several orders of magnitude. Therefore, activity concentrations for this experiment were selected which were both reasonable from the standpoint of simulating actual waste and practical from the standpoint of experimental considerations, e.g., detection limits and radiation dose levels. Actual activity contained ranged from approximately 17 to $48 \mu \mathrm{Ci}$ of each isotope per waste form, depending upon waste loading.

In order to evenly distribute the aqueous tracer activity throughout the dry powdered simulated sodium sulfate waste, the following procedure was employed. A quantity of sodium sulfate was weighed and then dissolved in distilled water at elevated temperature to increase solubility. The appropriate volumes of liquid tracer were pippeted and thoroughly mixed. The solution was evaporated to dryness and the remaining salt cake removed. The tracer activated sodium sulfate was then crushed to a fine powder by mortar and pestle.

Incinerator ash was prepared in a similar fashion. Tracers were pipetted into a slurry of ash and distilled water which was then throughly mixed. Upon evaporation the ash was also crushed to a fine powder.

Since waste-binder mixtures were not prohibitively viscous, modified sulfur cement leaching specimens were prepared in disposable glass beakers, wrapped with electrical resistance heaters and insulation. This procedure enabled the use of a new mixing container for each batch and eliminated concerns over cross-contamination. Heating was adjusted by a variable voltage controller and mixing was accomplished using an electrically driven impeller. Modified sulfur cement was pre-heated to a molten state. Waste was ther added and stirred for 10-20 minutes. The mixtures were then poured in polyethylene lined sample molds and allowed to cool. Apparent voids were refilled as necessary. Upon cooling, waste form heights were trimmed and the surfaces of the cut ends were resealed by means of a heat gun. Waste form dimensions were recorded for calculation of volumes and surface areas. Weights were taken so that waste form activity source terms could be calculated based upon the waste loading (wt\%) and final weight of each specimen.

5.5.3 Experimental Procedure. Specimens were leached in demineralized water. The volume of leachant employed ranged between 1470 and $1720 \mathrm{ml}$ as specified by the ratio of leachant volume to external geometric surface area of $10 \pm 0.2 \mathrm{~cm}$. Temperature was maintained at $20 \pm 2{ }^{\circ} \mathrm{C}$. Leachant was replenished at the recommended incremental intervals of 30 seconds, 2 hours, 5 hours, 17 hours, once each day for the next four days, 13, 28 and 45 days, for a total leaching time of 91 days.

Leachate aliquots of $100 \mathrm{ml}$ were collected for analysis, acidified with 1 $\mathrm{ml}$ of nitric acid and were then prepared for gamma counting. Leachate analyses were performed using a gemanium detector and computerized multichannel analyzer system. Data reduction was accomplished by use of several programs written for a Hewlett Packard HP-85 micro computer, which calculated incremental and cumulative fraction release, stored and printed tabular data and plotted leaching curves. 
5.5.4 Results. Average cumulative 137 Cs fraction release is plotted as a function of Teaching time (in days) for the sodium sulfate waste forms in Figure 5.12 and in Figure 5.14 for incinerator ash waste forms. Average cumulative 60 co fraction release is plotted as a function of leaching time for the sodium sulfate waste forms in Figure 5.13 and for incinerator ash specimens in Figure 5.15. Tabular leaching data for each individual specimens are presented in Appendix C.

The highest release rates were for $137 \mathrm{Cs}$ from the sodium sulfate waste forms. Maximum average fractional releases after 91 days of $2.04 \times 10^{-2}$ and $1.1 \times 10^{-1}$ were calculated for samples containing 25 and 40 wt\% sodium sulfate waste, respectively.

Cobalt fractional releases from the same waste forms were somewhat lower, indicating isotope-specific interactions affecting leachabjlity. Maximum average ${ }^{60}$ Co fractional releases after 91 days were $1.68 \times 10^{-3}$ and $4.25 \times 10^{-2}$ for samples containing 25 and 40 wt\% sodium sulfate waste, respectively. The increase in leachability as a function of waste loading is expected for a soluble salt waste where the release of radionuclides is usually proportional to the re? ease of soluble salt from the waste form.

Cesium leachability for modified sulfur cement waste forms containing incinerator ash do not appear to be dependent upon waste loading. The average cumulative fractional releases from sampies containing 40 and 20 wt\% ash were $6.69 \times 10^{-3}$ and $6.48 \times 10^{-3}$, respectively. These data represent an improvement of approximately one order of magnitude over $137 \mathrm{Cs}$ releases from sodium sulfate waste forms. The lowest release rates were recorded for 60 Co from modified sulfur cement waste forms containing ash. Average cumulative fractiona $i$ releases were $1.63 \times 10^{-4}$ for specimens containing 40 wt\% ash and 3.86 $\times 10^{-4}$ for those containing 20 wt\% ash.

In addition to cumulative fractional release and incremental release rate determinations, data were also calculated in terms of the "leachability index" as recommended in the ANS 16.1 method. This index is a dimensionless figure of merit which quantifies the relative leachability for a given waste typesolidification agent. It can thus be used as a basis for comparison of the radionuclide retention capabilities of various solidification matrix-waste type combinations. On a plant scale, the leachability index can be employed as a means of demonstrating that waste forms meet minimum quality assurance standards. As a result, the NRC has issued recommended minimum leachability index specifications in support of 10 CFR 61 waste forn stability requirements 26 .

The leachability index for a given radionuclide, $i$, is given by:29

$$
L_{i}=1 / 10 \sum_{n=1}^{10}\left[\log \left(\beta / D_{i}\right)\right]_{n} \quad \text { (Eq. 5.1) }
$$




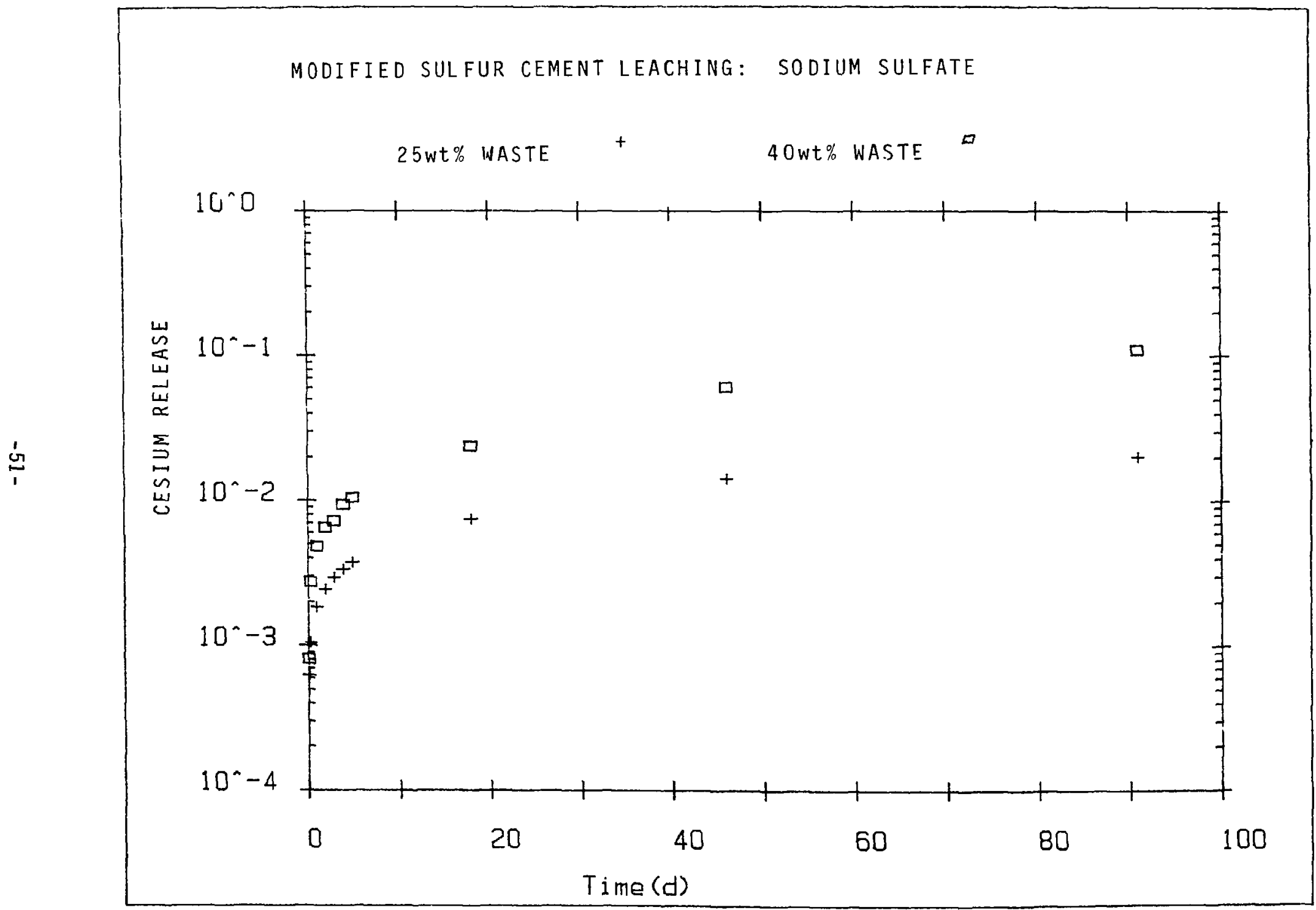

Figure 5.12 Cumulative Fractional Cesium Release for Modified Sulfur Cement Waste Form Containing 25 and $40 \mathrm{Wt} \%$ Sodium Sulfate. 


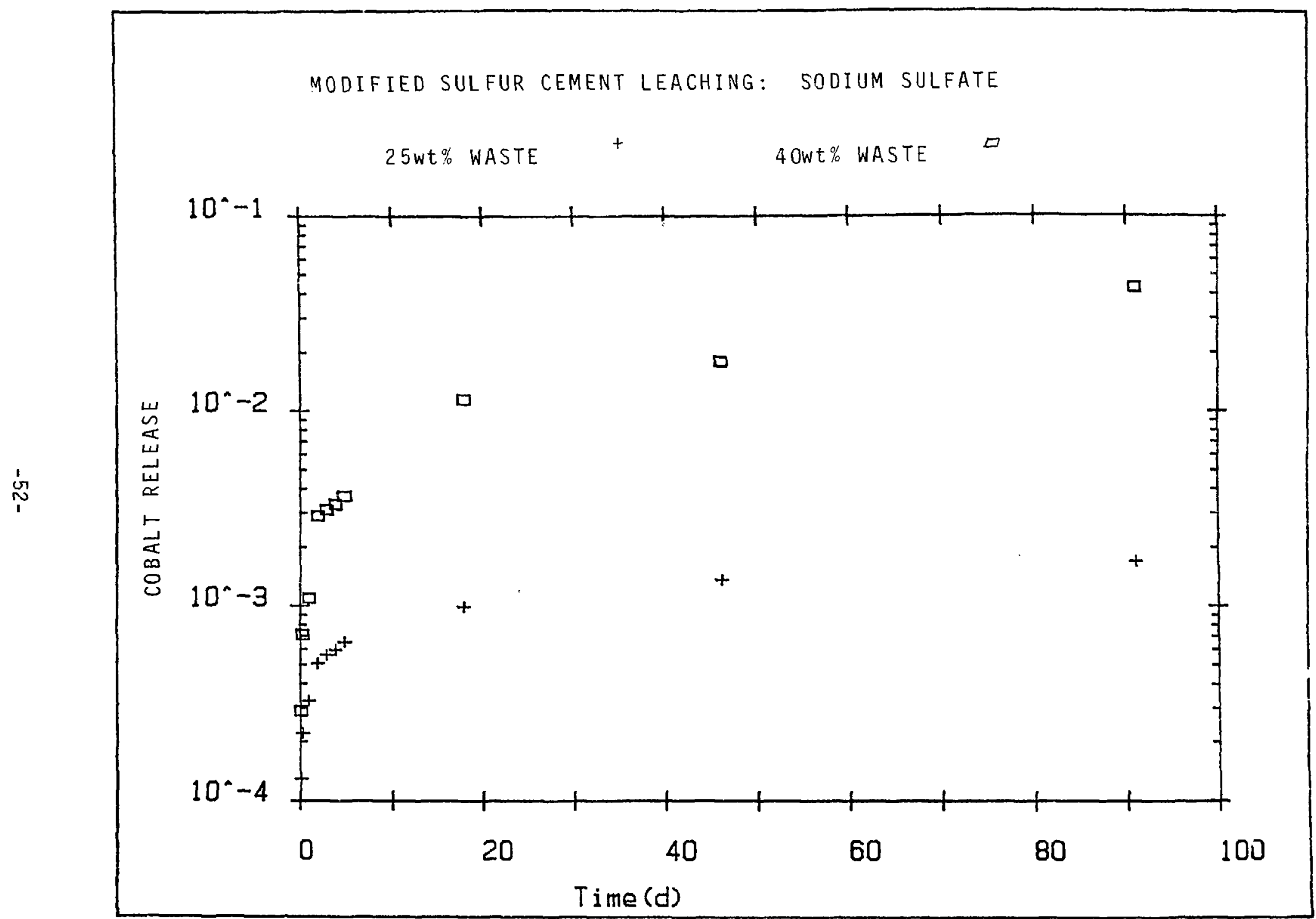

Figure 5.13 Cumulative Fractional Cobalt Release for Modified Sulfur Cement Waste Forms Containing 25 and $40 \mathrm{Wt} \%$ Sodium Sulfate. 


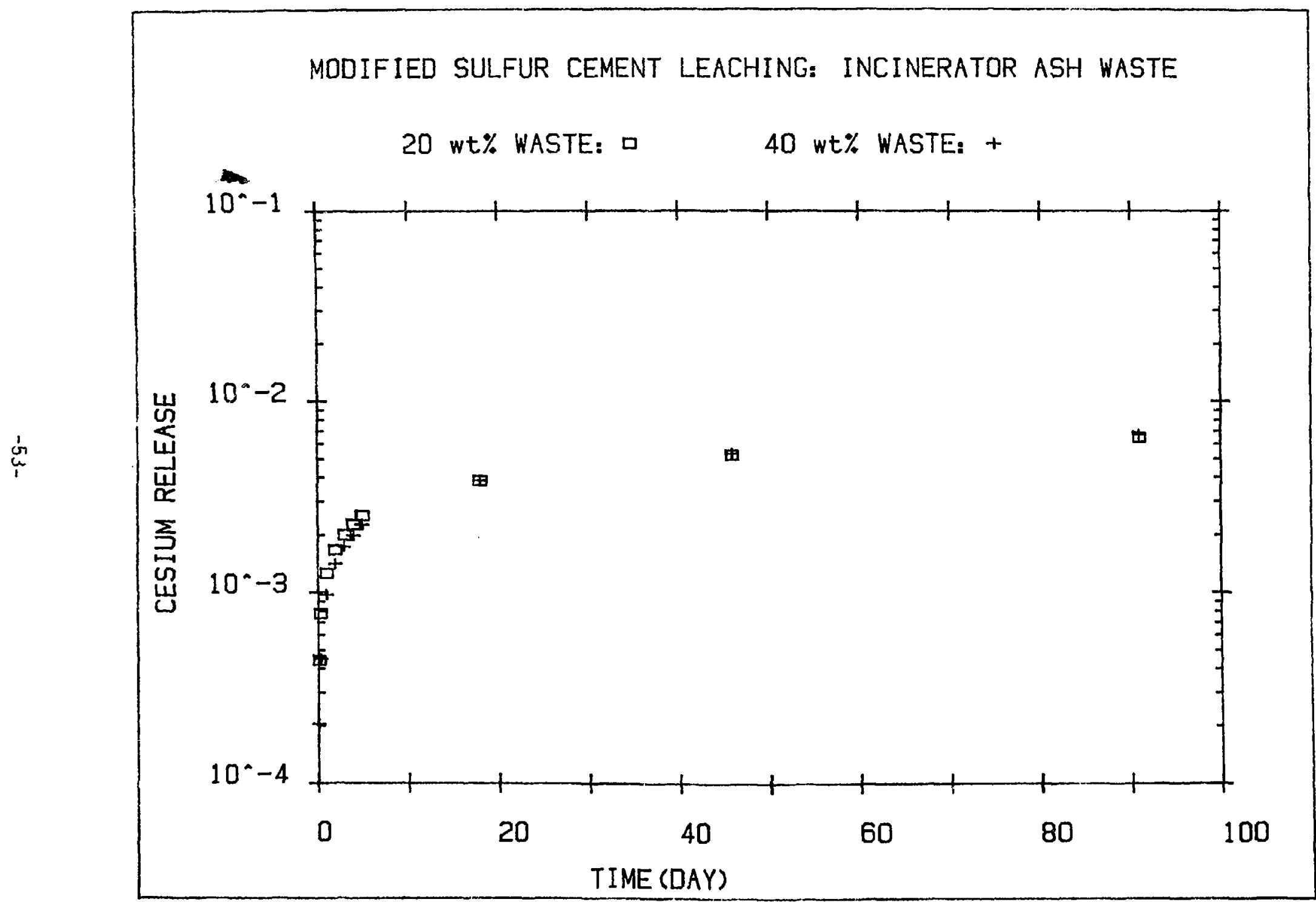

Figure 5.14 Cumulative Fractional Cesium Release for Modified Sulfur Cement Waste Forms Containing 20 and 40 wt\% Incinerator Ash. 


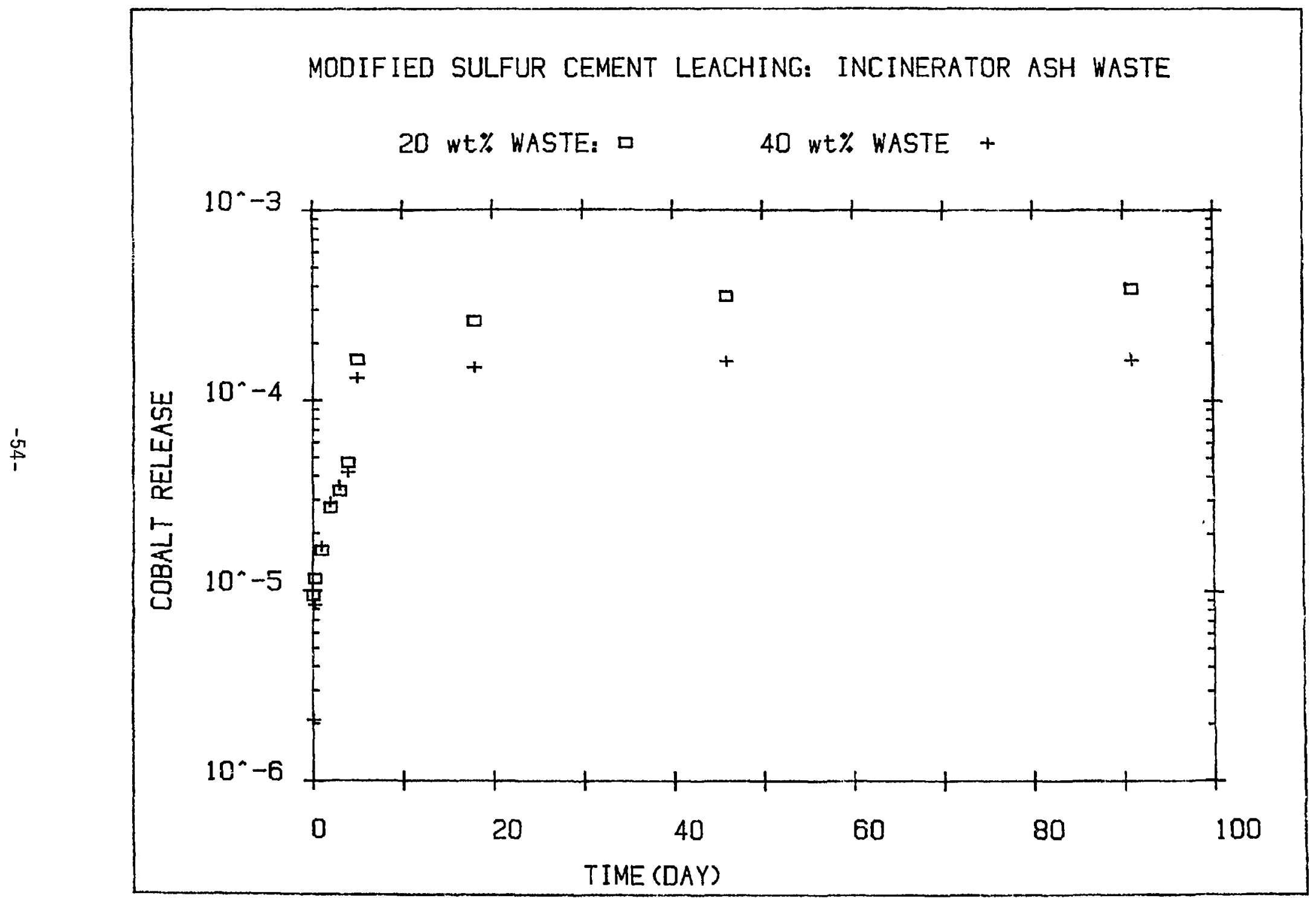

Figure 5.15 Cumulative Fractional Cobalt Release for Modified Sulfur Cement Waste Forms Containing 20 and 40 wt\% Incinerator Ash. 
where:

$$
\begin{aligned}
& B=1 \mathrm{~cm}^{2} / \mathrm{sec} \text { (defined constant) } \\
& D_{i}=\text { effective diffusivity }\left(\mathrm{cm}^{2} / \mathrm{sec}\right)
\end{aligned}
$$

The effective diffusivity is calculated from the leach test data by application of the following expression:

$$
D_{i}=\pi\left[\frac{a_{n} / A_{0}}{(\Delta t)_{n}}\right]^{2}(V / S)^{2} T
$$

where:

$$
\begin{aligned}
& a_{n}=\text { activity of a radionuclide released from the specimen during the } \\
& A_{0}=\text { total activity of a given radionuclide in the specimen at the } \\
& D_{i}=\text { effective diffusivity }\left(\mathrm{cm}^{2} / \mathrm{sec}\right) \\
& V=\text { volume of specimen }\left(\mathrm{cm}^{3}\right) \\
& \mathrm{S}=\text { geometric surface area of specimen }\left(\mathrm{cm}^{2}\right) \\
& T=\text { mean time of the leaching interval (sec) } \\
& (\Delta t)_{n}=\text { incremental leaching time (sec) }
\end{aligned}
$$

Average cesium and cobalt leachability index values for modified sulfur cement waste forms are presented in Table 5.4. Since the leachability index is inversely proportional to effective diffusivity, higher index values represent reduced leachability. As a means of comparison, the minimum $L_{j}$ recommended by NRC for commercial waste forms is 6.0 . All modified sulfur cement waste forms easily surpassed this criteria. 


\section{Table 5.4}

Average Leachability Indices for Modified Sulfur Cément Waste Forms(a),(b)

\begin{tabular}{|c|c|c|c|}
\hline $\begin{array}{l}\text { Waste } \\
\text { Type }\end{array}$ & $\begin{array}{l}\text { Waste } \\
\text { Loading } \\
(\text { Wt } \%)\end{array}$ & $\begin{array}{l}\text { Average } \\
\text { Leachabil ity } \\
\text { Index, }{ }^{60} \mathrm{Co}\end{array}$ & $\begin{array}{l}\text { Average } \\
\text { Leachability } \\
\text { Index, } 137 \text { Cs }\end{array}$ \\
\hline \multirow[t]{2}{*}{$\mathrm{Na}_{2} \mathrm{SO}_{4}$} & 25 & 12.5 & 10.6 \\
\hline & 40 & 10.7 & 9.7 \\
\hline \multirow[t]{2}{*}{ Incinerator Ash } & 20 & 14.0 & 11.2 \\
\hline & 40 & 14.6 & 11.1 \\
\hline
\end{tabular}

(a)Calculated as recommended in ANS 16.1 Test Method.

(b) Average of 2 replicate specimens. 


\section{SUMMARY AND CONCLUSIONS}

Maximum waste loadings for each waste type considered which can be successfully processed and yield a monolithic solid waste form are reported in Section 4. Results of waste form property evaluation testing are presented in Section 5. Recommended waste loadings which represent a balance between the quantity of waste which can be incorporated in modified sulfur cement while still maintaining desirable waste form properties are discussed in this section. A comparison of solidification efficiencies with hydraulic cement as currently employed for the majority of $L L W$ solidification and low-density polyethylene, also demonstrated at BNL as an improved solidification technology is provided, as well.

Increased waste loadings had a positive effect on sodium sulfate waste form compressive strength. Although both thermal cycling and water immersion resulted in moderate reductions in the compressive strength of tested samples, such reductions were not of sufficient magnitude to compromise structural integrity. At sodium sulfate waste loadings greater than or equal to $50 \mathrm{wt} \%$ salts, however, swelling and cracking occurred upon exposure to water. Optimal waste loadings of up to $40 \mathrm{wt} \%$ sodium sulfate are therefore recommended for solidification in modified sulfur cement.

A slight decrease in the compressive strength of modified sulfur cement waste forms containing boric acid was recorded as waste loading increased. Such reductions are not significant since the lowest mean compressive strength values were approximately 2000 psi. Thermal cycling did not adversely affect boric acid waste form strength. Reductions in strength were measured for samples containing $40 \mathrm{wt} \%$ boric acid upon completion of immersion testing, while those containing maximum loadings of $57 \mathrm{wt} \%$ failed in immersion. Optimal boric acid loadings in modified sulfur cement should therefore be limited to $40 \mathrm{wt} \%$ waste. Although leach testing for this waste type was not performed, the leachability is expected to be similar to that of sodium sulfate since the solubility for boric acid in water is essentially the same or less than that for sodium sulfate salt.

Incinerator ash compressive strength data were somewhat erratic, but since mean strength for each waste loading was in excess of 4000 psi, from a practical standpoint, this is of little concern. For most ash waste form formulations, thermal cycling and water immersion testing resulted in small reductions in compressive strength. Sufficient average strength ( $>2900 \mathrm{psi}$ ) was retained, however, to exceed requirements for transportation, storage and disposal operations. Leachability for all ash specimens tested was relatively low (minimum leachability index $0_{1}{ }^{\prime \prime} \cdot 1$ ). Based on these results, maximum loading of incinerator ash in modified sulfur cement is limited only by processing constraints, i.e. 43 wt\% ash.

Modified sulfur cement waste forms containing ion exchange resin wastes are susceptible to spalling upon exposure to atmospheric moisture and suffer severe deterioration upon saturation with water. Use of modified sulfur ceinent for encapsulation of these wastes is therefore not recommended. 
Optimal recommended waste loadings for modified sulfur cement waste forms are summarized in Table 6.1. Data comparing optimal loadings for hydraulic cement (based upon previous BNL waste form development studies for specimens which satisfied free-standing monolithic solid and two week water immersion criteria) 18,19,30 and for low-density polyethylene (based upon the same performance evaluation criteria employed for modified sulfur cement) 20 are presented, as well. In order to normalize for variations in product densities, data are given in terms of quantities of waste solidified per 55 gallon drum, in addition to wt\% waste loadings. The percentage improvement or reduction in waste loadings for modified sulfur cement versus hydraulic cement and polyethylene are given in Table 6.2. With the exception of ion exchange resin wastes, significant waste loading improvements for modified sulfur cement are achieved (ranging from 20 to 500\%), as compared with hydraulic cement. In comparison with low-density polyethylene, $51 \%$ additional incinerator ash waste, $34 \%$ less sodium sulfate waste and approximately the same quantity of boric acid can be incorporated.

Progress and significant highlights in the area of modified sulfur cement waste form process development are summarized by the following points:

- Improvements in processing modified sulfur cement waste forms over the results achieved by extrusion were made possible by use of the dual action mixer. Low mixture viscosities which impeded material conveyance through the extruder barrel were well suited for the vortex stirring action provided by the mixer.

- Pre-heating of modified sulfur cement to its molten state with the gradual addition of waste solids, resulted in mixtures which were more readily processed, especially when approaching maximum loadings.

- Close attention must be paid to control process temperatures in the range of $120-150^{\circ} \mathrm{C}$. Lower temperatures will result in incomplete or partial melting of the sulfur. Excessive temperatures can increase mixture viscosity and for some waste types, e.g. boric acid, adversely affect waste form integrity.

- Modified sulfur cement tends to form void cavities upon cooling to the solid phase. This tendency is lessened with the addition of waste solids and can be further reduced by filling drums in incremental steps, allowing the mixture to solidify between fillings.

- Thorough homogenization of waste and binder and reproducibility within batches was demonstrated by good agreement in apparent density measurements.

In conclusion, the use of modified sulfur cement as a potential binder material for the improved solidification of certain LLW streams has been established. With the exception of ion exchange resin wastes, compatibility with the waste types investigated was good. Significant improvements in solidification efficiencies, as compared with hydraulic cement, were demonstrated. For optimal recommended formulations (as given in Table 6.1) performance should surpass minimum criteria for storage, handling and disposal operations. 
Comparison of Optimal Recommended Waste Loadings for Modified Sulfur Cement, Hydraulic Cement and Polyethylene Based on Processing and Waste Form Performance Considerations

\begin{tabular}{llcc}
\multicolumn{4}{c}{ Waste Type } \\
\hline $\begin{array}{l}\text { Sodium } \\
\text { Sulfate }\end{array}$ & $\begin{array}{c}\text { Boric } \\
\text { Acid }\end{array}$ & $\begin{array}{c}\text { Incinerator } \\
\text { Ash }\end{array}$ & $\begin{array}{c}\text { Ion Echange } \\
\text { Resins }\end{array}$ \\
\end{tabular}

Solidification in

Modified Sulfur Cement:

\begin{tabular}{|c|c|c|c|c|}
\hline Wt\% Waste(a) & 40 & 40 & 43 & Not Recommended \\
\hline Drum wt., $\underset{(\mathrm{kg} \text { (b) }}{\mathrm{kbs})}$ & $\begin{array}{c}415 \\
(915)\end{array}$ & $\begin{array}{l}287 \\
(633)\end{array}$ & $\begin{array}{c}384 \\
(846)\end{array}$ & -- \\
\hline Waste/Drum, $\begin{array}{c}\mathrm{kg}(\mathrm{c}) \\
(1 \mathrm{bs})\end{array}$ & $\begin{array}{c}166 \\
(366)\end{array}$ & $\begin{array}{l}115 \\
(253)\end{array}$ & $\begin{array}{c}182 \\
(360)\end{array}$ & -- \\
\hline \multicolumn{5}{|c|}{$\begin{array}{l}\text { Sol idification in } \\
\text { Hydraulic Cement: (d) }\end{array}$} \\
\hline Wt\% Waste $(a)$ & 9 & 15 & 40 & 13 \\
\hline Drum wt., $\underset{(\mathrm{lbs})}{\mathrm{kg}(\mathrm{b})}$ & $\begin{array}{l}307 \\
678\end{array}$ & $\begin{array}{l}296 \\
(653)\end{array}$ & $\begin{array}{c}318 \\
(700)\end{array}$ & $\begin{array}{c}318 \\
(700)\end{array}$ \\
\hline Waste/Drum, $\underset{(\mathrm{lbs})}{\mathrm{kg}(\mathrm{c})}$ & $\begin{array}{l}28 \\
(61)\end{array}$ & $\begin{array}{c}44 \\
(98)\end{array}$ & $\begin{array}{c}127 \\
(280)\end{array}$ & $\begin{array}{c}41 \\
(91)\end{array}$ \\
\hline \multicolumn{5}{|l|}{$\begin{array}{l}\text { Solidification in } \\
\text { Polyethylene: }(e)^{n}\end{array}$} \\
\hline Wt\% Waste (a) & 70 & 50 & 40 & 30 \\
\hline Drum Wt., $\underset{(1 \mathrm{bs})}{\mathrm{kg}(\mathrm{b})}$ & $\begin{array}{c}358 \\
(789)\end{array}$ & $\begin{array}{c}225 \\
(496)\end{array}$ & $\begin{array}{c}270 \\
(595)\end{array}$ & $\begin{array}{c}210 \\
(463)\end{array}$ \\
\hline Waste/Drum, $\begin{array}{c}\mathrm{kg}(\mathrm{c}) \\
(\mathrm{lbs})\end{array}$ & $\begin{array}{l}250 \\
(552)\end{array}$ & $\begin{array}{c}133 \\
(248)\end{array}$ & $\begin{array}{c}108 \\
(238)\end{array}$ & $\begin{array}{c}63 \\
(139)\end{array}$ \\
\hline
\end{tabular}

a) Based on dry solid weight.

b) 55 gallon drum size waste form.

c) Equivalent quantity of waste which can be incorporated in 55 gallon drum size waste form.

d) Based on previous BNL waste form development studies for waste forms which satisfied free-standing monolithic sol id and two-week water immersion criteria18,19,30.

e) Based on data from Reference 20 . 
Table 6.2

Percentage Improvement or Reduction in Waste Loading for Modified Sulfur Cement Versus Hydraulic Cement and Polyethylene

\% Increase/Decrease In Waste Loadings As Compared With: (a)

Waste Type Hydraulic Cem:ent

Low Density Polyethylene

Sodium Sulfate

$+500 \%$

$-34 \%$

Boric Acid

$+158 \%$

$+2 \%$

Incinerator Ash

$+29 \%$

$+51 \%$

a) Based on waste/drum as given in Table 6.1 . 


\section{REFERENCES}

1. Kalb, P.D. and P. Colombo, Selection of Improved Solidification Agents for Further Investigation, BNL-33404, Brookhaven National Laboratory, Upton, NY, February 1983.

2. Colombo, P., P.D. Kalb and M. Fuhrmann, Waste Form Development Program Annual Report, BNL-51756, Brookhaven National Laboratory, Upton, NY, September 1983.

3. Raymont, M.E.D., "Sulpfur Concrete and Coatings," New Uses for Sulphur Technology of Canada (SUDIC), Calgary, Alberta, Canada, 1978.

4. "U.S. Bureau of Mines Transfers Sulphur Concrete Technology to Industry," Sulphur Research and Development, Vol. 2, 1979.

5. "Sulphur Concrete.... A New Construction Material Comes of Age," Sulphur Research and Development, Vol. 2, 1979.

6. "SCRETE Sulfur Concrete," Manufacturer's Data Sheet, Chevron Chemical Co., San Francisco, CA.

7. "CHEMENT 2000," Manufacturer's Data Sheet, Chemical Enterprises, Inc., Houston, TX.

8. Weast, R.C. ed., Handbook of Chemistry and Physics, 56th Editions, CRC Press, Cleveland, $\mathrm{OH}, 1976$.

9. Corrins, C.W., Introduction to Mineralogy, Crystallography and Petrology, Springer-Verlag, New York, 1969.

10. Sullivan, T.A. and W.C. McBee, Development and Testing of Superior SuTfur Concretes, RI-8160, Bureau of Mines, U.S. Dept. of the Interior, Washington, DC, 1976.

11. McBee, W.C., T.A. Sullivan and B.W. Jong, Modified Sulfur Cements for Use in Concretes, Flexible Pavings, Coatings and Grouts, RI-8545, Bureau of Mines, U.S. Dept. of the Interior, Washington, DC, 1981.

12. Oak Ridge National Laboratory, Spent Fuel and Radioactive Inventories and Projections, DOE/NE-0017/2, ORNL, Oak Ridge, TN, September 1983.

13. USNRC, "Licensing Requirements for Land Disposal of Radioactive Waste," Title 10 of the Code of Federal Regulations, Part 61, US Nuclear ReguTatory Commission, Washington, DC, May 1983.

14. Fuhrmann, M. and P. Col ombo, Selection of Waste Types for Use With Improved Agents, BNL-33405, Brookhaven National Laboratory, Upton, NY, Apri1 1983.

15. Kalb, P.D. and P. Colombo, "A Economic Analysis of a Fluidized-Bed Volume Reduction System," American Nuclear Society Transactions, Vol. 46, 1984 Annual Meeting, New Orleans, LA, June 1984. 


\section{REFERENCES (cont.)}

16. Dlouhy, Z., Disposal of Radioactive Wastes, Studies in Environmental Science, Vol. 15, Elsevier Scientific PubTishing Co., Amsterdam, The Netherlands, 1982.

17. Mullarkey, T.B., T.L. Jentz, J.M. Connelly, and J.P. Kane, A Survey and Evaluation of Handling and Disposing of Solid Low-Level Nuclear Cycle Wastes, AIF/NESP-008, NUS Corporation, Rockville, Maryland, 1976.

18. Neilson, R.M., Jr., P.D. Kalb, M. Fuhrmann and P. Colombo, "Solidification of Ion Exchange Resin Wastes in Hydraulic Cement," Published in The Treatment and Handling of Radioactive Wastes, A.G. Blasewitz, J.M. Davis, M.R. Smith, ed., Springer-Verlag, New York, 1983.

19. Neilson, R.M., Jr., and P. Colombo, Waste Form Development Program Annual Progress Report, BNL-51614, Brookhaven National Laboratory, Upton, NY, September 1982 .

20. Kalb, P.D. and P. Colombo, Polyethylene Solidification of Low-Level Wastes, Topical Report, BNL-51867, Brookhaven National Laboratory, Upton, NY, October, 1984.

21. Fitzgerald, C.L., H.W. Godbee, R.E. Blanco and W. Davis, Jr., "The Feasibility of Incorporating Radioactive Wastes in Asphalt or Polyethylene," Nuclear Applications and Technology, Vol. 9, December, 1970.

22. Senning, A., Sulfur in Organic and Inorganic Chemistry, Vol. 3, Marca? Dekker, Inc., New York, 1972.

23. Neilson, R.M., Jr., and P. Colombo, Solidification of Ion Exchange Resin Wastes, BNL-51615, Brookhaven National Laboratory, Ijpton, NY, August 1982 .

24. Meyer, B., Sulfur, Energy and Environment, Elsevier Scientific Publishing Co., New York, 1977.

25. Colombo, P., M. Fuhrmann and S. Levine, Prel iminary Waste Form Evaluation Criteria, BNL-33403, Brookhaven National Laboratory, Upton, NY, December 1982.

26. USNRC, "Technical Position on Waste Form," US Nuclear Regulatory Commission, Low-level Waste Licensing Branch, Washington, DC, May 1983.

27. ASTM, Standard Method of Test for Compressive Strength of Cylindrical Concrete Specimens, C39-72, American Society for Testing and Materials, Philadelphia, PA, 1975.

28. ASTM, Standard Method of Test for Thermal Cycling of Electroplated Plastics, B-553, American Society for Testing and Materials, Philadelphia, PA, 1979. 


\section{REFERENCES (cont.)}

29. ANS Standards Committee, Working Group 16.1, Measurement of the Leachability of Solidified Low-Level Wastes, American Nuclear Society, June 1984.

30. Zhou, H. and P. Colombo, "Solidification of Radioactive Waste in a Cement Lime Mixture," Waste Isolation in the U.S., Technical Programs and Public Education, Vol. 2, Low-Level Waste, Volume Reduction Methodologies and Economics, Proceedings of Waste Management '84, Tucson, AZ, March 1984.

31. Killion Model KL-125, Manufacturer's Specifications, Killion Extruders, Inc., Verona, NJ, 1983. 


\section{APPENDIX A}

Extruder Process Parameters for Representative Modified Sulfur Cement Waste Forms 
Table A-1

Extruder Parameters for Selected Modified Sulfur Cement/Sodium Sulfate Solidification Formulations

\begin{tabular}{|c|c|c|c|c|c|c|c|c|c|}
\hline \multirow[b]{2}{*}{ Run No. } & \multirow[b]{2}{*}{$\begin{array}{l}\text { Dry } \\
\text { Waste } \\
\text { Wt\% } \\
\end{array}$} & \multicolumn{4}{|c|}{$\begin{array}{l}\text { Temperature Control } \\
\left.\text { Settings }{ }^{\circ} \mathrm{C},{ }_{2}^{\circ} \mathrm{F}\right)\end{array}$} & \multicolumn{4}{|c|}{ Instrumentation Readings } \\
\hline & & $\begin{array}{c}\text { Zone } \\
1 \\
\end{array}$ & $\begin{array}{c}\text { Zone } \\
2 \\
\end{array}$ & $\begin{array}{c}\text { Zone } \\
3 \\
\end{array}$ & $\begin{array}{l}\text { Die } \\
\text { Zone } \\
\end{array}$ & $\begin{array}{l}\text { Melt } \\
\text { Temp. } \\
{ }^{\circ} \mathrm{C}\left({ }^{\circ} \mathrm{F}\right)\end{array}$ & $\begin{array}{l}\text { Melt } \\
\text { Press } \\
\text { MPa, (psi) }\end{array}$ & $\begin{array}{l}\text { Load, } \\
\text { Amps } \\
\end{array}$ & $\begin{array}{c}\text { Screw } \\
\text { Speed } \\
\text { RPM } \\
\end{array}$ \\
\hline $6-2-6$ & 30 & $\begin{array}{c}65 \\
(150)\end{array}$ & $\begin{array}{c}121 \\
(250)\end{array}$ & $\begin{array}{c}135 \\
(275)\end{array}$ & $\begin{array}{l}135 \\
(275)\end{array}$ & $\begin{array}{c}128 \\
(263)\end{array}$ & 0 & 2 & 30 \\
\hline $6-2-7$ & 40 & $\begin{array}{c}107 \\
(225)\end{array}$ & $\begin{array}{l}135 \\
(275)\end{array}$ & $\begin{array}{l}149 \\
(300)\end{array}$ & $\begin{array}{c}149 \\
(300)\end{array}$ & $\begin{array}{c}138 \\
(280)\end{array}$ & 0 & 1 & 30 \\
\hline $6-2-8$ & 50 & $\begin{array}{c}107 \\
(225)\end{array}$ & $\begin{array}{c}135 \\
(275)\end{array}$ & $\begin{array}{c}149 \\
(300)\end{array}$ & $\begin{array}{c}149 \\
(300)\end{array}$ & $\begin{array}{l}138 \\
(280)\end{array}$ & 0 & 1 & 30 \\
\hline $6-7-1$ & 60 & $\begin{array}{c}107 \\
(225)\end{array}$ & $\begin{array}{l}135 \\
(275)\end{array}$ & $\begin{array}{l}149 \\
(300)\end{array}$ & $\begin{array}{l}149 \\
(300)\end{array}$ & $\begin{array}{c}139 \\
(283)\end{array}$ & $\begin{array}{l}0.28 \\
(40)\end{array}$ & 1 & 30 \\
\hline $6-7-3$ & 65 & $\begin{array}{l}107 \\
(225)\end{array}$ & $\begin{array}{c}135 \\
(275)\end{array}$ & $\begin{array}{l}149 \\
(300)\end{array}$ & $\begin{array}{c}149 \\
(300)\end{array}$ & $\begin{array}{l}139 \\
(283)\end{array}$ & $\begin{array}{l}0.28 \\
(40)\end{array}$ & 1 & 30 \\
\hline
\end{tabular}


Table A-2

Extruder Parameters for Selected Modified Sulfur Cement/Boric Acid Solidification Formulations

\begin{tabular}{|c|c|c|c|c|c|c|c|c|c|}
\hline \multirow[b]{2}{*}{ Run No. } & \multirow[b]{2}{*}{$\begin{array}{l}\text { Dry } \\
\text { Waste } \\
\text { Wt\% } \\
\end{array}$} & \multicolumn{4}{|c|}{$\begin{array}{l}\text { Temperature Control } \\
\left.\text { Settings }{ }^{\circ} \mathrm{C},{ }^{\circ}{ }^{\circ} \mathrm{F}\right)\end{array}$} & \multicolumn{4}{|c|}{ Instrumentation Readings } \\
\hline & & $\begin{array}{c}\text { Zone } \\
1 \\
\end{array}$ & $\begin{array}{c}\text { Zone } \\
2 \\
\end{array}$ & $\begin{array}{c}\text { Zone } \\
3 \\
\end{array}$ & $\begin{array}{l}\text { Die } \\
\text { Zone } \\
\end{array}$ & $\begin{array}{l}\text { Melt } \\
\text { Temp. } \\
{ }^{\circ} \mathrm{C}\left({ }^{\circ} \mathrm{F}\right) \\
\end{array}$ & $\begin{array}{l}\text { Melt } \\
\text { Press } \\
\text { MPa, (psi) }\end{array}$ & $\begin{array}{l}\text { Load, } \\
\text { Amps }\end{array}$ & $\begin{array}{c}\text { Screw } \\
\text { Speed } \\
\text { RPM } \\
\end{array}$ \\
\hline $6-8-1$ & 20 & $\begin{array}{c}79 \\
(175)\end{array}$ & $\begin{array}{l}121 \\
(250)\end{array}$ & $\begin{array}{c}121 \\
(250)\end{array}$ & $\begin{array}{l}135 \\
(275)\end{array}$ & $\begin{array}{l}126 \\
(259)\end{array}$ & 0 & 1 & 40 \\
\hline $6-8-3$ & 30 & $\begin{array}{c}79 \\
(175)\end{array}$ & $\begin{array}{c}121 \\
(250)\end{array}$ & $\begin{array}{l}121 \\
(250)\end{array}$ & $\begin{array}{l}135 \\
(275)\end{array}$ & $\begin{array}{l}126 \\
(259)\end{array}$ & 0 & 1 & 40 \\
\hline $6-14-1$ & 35 & $\begin{array}{c}79 \\
(175)\end{array}$ & $\begin{array}{c}121 \\
(250)\end{array}$ & $\begin{array}{l}121 \\
(250)\end{array}$ & $\begin{array}{l}149 \\
(300)\end{array}$ & $\begin{array}{l}140 \\
(284)\end{array}$ & 0 & 2 & 30 \\
\hline $6-8-2$ & 40 & $\begin{array}{c}79 \\
(175)\end{array}$ & $\begin{array}{c}121 \\
(250)\end{array}$ & $\begin{array}{l}121 \\
(250)\end{array}$ & $\begin{array}{l}135 \\
(275)\end{array}$ & $\begin{array}{c}127 \\
(261)\end{array}$ & 0 & 2 & 30 \\
\hline
\end{tabular}


Table A-3

Extruder Parameters for Selected Modified Sulfur Cement/Incinerator Ash Solidification Formulations

\begin{tabular}{|c|c|c|c|c|c|c|c|c|c|}
\hline \multirow[b]{2}{*}{ Run No. } & \multirow[b]{2}{*}{$\begin{array}{l}\text { Dry } \\
\text { Waste } \\
\text { Wt\% } \\
\end{array}$} & \multicolumn{4}{|c|}{$\begin{array}{l}\text { Temperature Control } \\
\text { Settings }{ }^{\circ} \mathrm{C},\left({ }^{\circ} \mathrm{F}\right)\end{array}$} & \multicolumn{4}{|c|}{ Instrumentation Readings } \\
\hline & & $\begin{array}{c}\text { Zone } \\
1 \\
\end{array}$ & $\begin{array}{r}\text { Zone } \\
2 \\
\end{array}$ & $\begin{array}{l}\text { Zone } \\
3 \\
\end{array}$ & $\begin{array}{l}\text { Die } \\
\text { Zone } \\
\end{array}$ & $\begin{array}{l}\text { Melt } \\
\text { Temp. } \\
{ }^{\circ} \mathrm{C}\left({ }^{\circ} \dot{F}\right) \\
\end{array}$ & $\begin{array}{l}\text { Melt } \\
\text { Press } \\
\text { MPa, (psi) }\end{array}$ & $\begin{array}{l}\text { Load, } \\
\text { Amps }\end{array}$ & $\begin{array}{c}\text { Screw } \\
\text { Speed } \\
\text { RPM } \\
\end{array}$ \\
\hline $6-14-7$ & 10 & $\begin{array}{c}79 \\
(175)\end{array}$ & $\begin{array}{c}121 \\
(250)\end{array}$ & $\begin{array}{c}121 \\
(250)\end{array}$ & $\begin{array}{c}149 \\
(300)\end{array}$ & $\begin{array}{c}138 \\
(281)\end{array}$ & 0 & 2 & 30 \\
\hline $6-14-8$ & 20 & $\begin{array}{c}79 \\
(175)\end{array}$ & $\begin{array}{c}121 \\
(250)\end{array}$ & $\begin{array}{c}12 ! \\
(250)\end{array}$ & $\begin{array}{c}149 \\
(300)\end{array}$ & $\begin{array}{c}137 \\
(278)\end{array}$ & 0 & 2 & 30 \\
\hline
\end{tabular}


Table A-4

Extruder Parameters for Selected Modified Sulfur Cement/Ion Exchange Resin Solidification Formulations

\begin{tabular}{|c|c|c|c|c|c|c|c|c|c|}
\hline \multirow[b]{2}{*}{ Run No. } & \multirow[b]{2}{*}{$\begin{array}{l}\text { Dry } \\
\text { Waste } \\
\text { Wt\% } \\
\end{array}$} & \multicolumn{4}{|c|}{$\begin{array}{l}\text { Temperature Control } \\
\text { Settings }{ }^{\circ} \mathrm{C},\left({ }^{\circ} \mathrm{F}\right)\end{array}$} & \multicolumn{4}{|c|}{ Instrumentation Readings } \\
\hline & & $\begin{array}{c}\text { Zone } \\
1 \\
\end{array}$ & $\begin{array}{c}\text { Zone } \\
2 \\
\end{array}$ & $\begin{array}{c}\text { Zone } \\
3 \\
\end{array}$ & $\begin{array}{l}\text { Die } \\
\text { Zone } \\
\end{array}$ & $\begin{array}{l}\text { Melt } \\
\text { Temp. } \\
\text { oC }\left({ }^{\circ} \mathrm{F}\right)\end{array}$ & $\begin{array}{l}\text { Melt } \\
\text { Press } \\
\text { MPa, (psi) }\end{array}$ & $\begin{array}{l}\text { Load, } \\
\text { Amps } \\
\end{array}$ & $\begin{array}{c}\text { Screw } \\
\text { Speed } \\
\text { RPM } \\
\end{array}$ \\
\hline $6-14-2$ & 10 & $\begin{array}{c}79 \\
(175)\end{array}$ & $\begin{array}{c}121 \\
(250)\end{array}$ & $\begin{array}{c}121 \\
(250)\end{array}$ & $\begin{array}{c}149 \\
(300)\end{array}$ & $\begin{array}{c}139 \\
(283)\end{array}$ & 0 & 2 & 30 \\
\hline $6-14-5$ & 20 & $\begin{array}{c}79 \\
(175)\end{array}$ & $\begin{array}{c}121 \\
(250)\end{array}$ & $\begin{array}{c}121 \\
(250)\end{array}$ & $\begin{array}{c}149 \\
(300)\end{array}$ & $\begin{array}{c}139 \\
(282)\end{array}$ & 0 & 2 & 40 \\
\hline $6-14-3$ & 30 & $\begin{array}{c}79 \\
(175)\end{array}$ & $\begin{array}{c}121 \\
(250)\end{array}$ & $\begin{array}{c}121 \\
(250)\end{array}$ & $\begin{array}{l}149 \\
(300)\end{array}$ & $\begin{array}{l}139 \\
(282)\end{array}$ & 0 & 2 & 40 \\
\hline $6-14-6$ & 40 & $\begin{array}{c}79 \\
(175)\end{array}$ & $\begin{array}{c}121 \\
(250)\end{array}$ & $\begin{array}{c}121 \\
(250)\end{array}$ & $\begin{array}{c}149 \\
(300)\end{array}$ & $\begin{array}{l}140 \\
(284)\end{array}$ & 0 & 2 & 30 \\
\hline
\end{tabular}


APPENDIX B

Dual Action Mixer Process Parameters for Representative Modified Sulfur Cement Waste Forms 
Table B-1

Dual Action Mixer Process Parameters for Selected Sodium Sulfate Solidification Formulations

\begin{tabular}{|c|c|c|c|c|}
\hline Run No. & $\begin{array}{l}\text { Dry } \\
\text { Waste } \\
\% \\
\end{array}$ & $\begin{array}{l}\text { Temp. } \\
\text { Control } \\
\text { Set, } \\
{ }^{\circ} \mathrm{C},\left({ }^{\circ} \mathrm{F}\right)\end{array}$ & $\begin{array}{l}\text { Melt } \\
\text { Temp.; } \\
{ }^{\circ} \mathrm{C}\left({ }^{\circ} \mathrm{F}\right)\end{array}$ & $\begin{array}{l}\text { Mix } \\
\text { Time, } \\
\text { min. }\end{array}$ \\
\hline $1-15-1$ & 30 & $\begin{array}{c}129 \\
(265)\end{array}$ & $\begin{array}{c}125 \\
(257)\end{array}$ & 5 \\
\hline $6-19-1$ & 40 & $\begin{array}{c}129 \\
(265)\end{array}$ & $\begin{array}{l}127 \\
(260)\end{array}$ & 5 \\
\hline $1-17-1$ & 50 & $\begin{array}{c}129 \\
(265)\end{array}$ & $\begin{array}{l}127 \\
(260)\end{array}$ & 5 \\
\hline $6-19-3$ & 60 & $\begin{array}{c}132 \\
(270)\end{array}$ & $\begin{array}{c}129 \\
(264)\end{array}$ & 5 \\
\hline $6-21-1$ & 70 & $\begin{array}{l}126 \\
(259)\end{array}$ & $\begin{array}{c}122 \\
(252)\end{array}$ & 10 \\
\hline $4-11-1$ & 75 & $\begin{array}{l}127 \\
(260)\end{array}$ & $\begin{array}{c}122 \\
(252)\end{array}$ & 10 \\
\hline $4-11-2$ & 80 & $\begin{array}{c}127 \\
(260)\end{array}$ & $\begin{array}{c}122 \\
(252)\end{array}$ & 10 \\
\hline
\end{tabular}


Table B-2

Dual Action Mixer Process Parameters for Selected Modified Sulfur Cement/Incinerator Ash Solidification Formulations

\begin{tabular}{|c|c|c|c|c|}
\hline Run No. & $\begin{array}{l}\text { Dry } \\
\text { Waste } \\
\% \\
\end{array}$ & $\begin{array}{l}\text { Temp. } \\
\text { Control } \\
\text { Set, } \\
{ }^{\circ} \mathrm{C},\left(^{\circ} \mathrm{F}\right)\end{array}$ & $\begin{array}{l}\text { Melt } \\
\text { Temp.; } \\
{ }^{\circ} \mathrm{C}\left({ }^{\circ} \mathrm{F}\right)\end{array}$ & $\begin{array}{l}\text { Mix } \\
\text { Time, } \\
\text { min. } \\
\end{array}$ \\
\hline$i-22-1$ & 20 & $\begin{array}{c}123 \\
(254)\end{array}$ & $\begin{array}{c}121 \\
(250)\end{array}$ & 5 \\
\hline $1-22-2$ & 30 & $\begin{array}{c}123 \\
(254)\end{array}$ & $\begin{array}{c}121 \\
(250)\end{array}$ & 5 \\
\hline $1-23-1$ & 40 & $\begin{array}{c}125 \\
(257)\end{array}$ & $\begin{array}{c}122 \\
(252)\end{array}$ & 5 \\
\hline $4-12-1$ & 50 & $\begin{array}{l}132 \\
(270)\end{array}$ & $\begin{array}{c}128 \\
(262)\end{array}$ & 10 \\
\hline $4-12-2$ & 57 & $\begin{array}{c}132 \\
(270)\end{array}$ & $\begin{array}{c}128 \\
(262)\end{array}$ & 10 \\
\hline
\end{tabular}


Table $B-3$

Dual Action Mixer Process Parameters for Selected Modified Sulfur Cement/Incinerator Ash Solidification Formulations

\begin{tabular}{|c|c|c|c|c|}
\hline Run No. & $\begin{array}{l}\text { Dry } \\
\text { Waste } \\
\% \\
\end{array}$ & $\begin{array}{l}\text { Temp. } \\
\text { Control } \\
\text { Set, } \\
{ }^{\circ} \mathrm{C},\left({ }^{\circ} \mathrm{F}\right)\end{array}$ & $\begin{array}{l}\text { Melt } \\
\text { Temp. } \\
{ }^{\circ} \mathrm{C}\left({ }^{\circ} \mathrm{F}\right)\end{array}$ & $\begin{array}{l}\text { Mix } \\
\text { Time, } \\
\text { min. }\end{array}$ \\
\hline $11-8-1$ & 10 & $\begin{array}{c}123 \\
(254)\end{array}$ & $\begin{array}{c}121 \\
(250)\end{array}$ & 5 \\
\hline $11-13-1$ & 20 & $\begin{array}{c}123 \\
(254)\end{array}$ & $\begin{array}{c}121 \\
(250)\end{array}$ & 5 \\
\hline $11-26-1$ & 30 & $\begin{array}{c}124 \\
(255)\end{array}$ & $\begin{array}{c}122 \\
(252)\end{array}$ & 5 \\
\hline $11-27-1$ & 40 & $\begin{array}{c}127 \\
(260)\end{array}$ & $\begin{array}{c}124 \\
(255)\end{array}$ & 5 \\
\hline $11-28-1$ & 43 & $\begin{array}{c}127 \\
(260)\end{array}$ & $\begin{array}{c}124 \\
(255)\end{array}$ & 10 \\
\hline
\end{tabular}


APPENDIX C

Tabular Leaching Data

Key

$$
\begin{aligned}
& \text { IIME = Cumulative leaching time, days } \\
& \text { CPM = Counts per minute } \\
& \text { IFR = Incremental fractional release } \\
& \text { CFR = Cumulative fractional release } \\
& \text { IRR,d = Incremental release rate, days-1 } \\
& \text { IRR, }=\text { Incremental release, seconds-1 }
\end{aligned}
$$


Table $\mathrm{C}-1$

\section{Wt\% Sodium Sulfate in Modified Sulfur Cement}

PILE: $\quad 85-8-1$

STOFED ONI DISC: PK DI

85-5 LEACHATE COUNTING DATÁ (CPIH):

$\begin{array}{rrrr}i & T I M E & C S & C O \\ 1 & 0.08 & 4.3 & 2.0 \\ 2 & 0.29 & 2.7 & 1.0 \\ 3 & 1.00 & 5.4 & 1.4 \\ 4 & 2.00 & 3.7 & 1.8 \\ 5 & 3.00 & 3.1 & 0.5 \\ 6 & 1.00 & 2.7 & 0.3 \\ 7 & 5.00 & 2.4 & 0.6 \\ 8 & 18.00 & 29.5 & 3.5 \\ 9 & 46.00 & 35.0 & 5.2 \\ 10 & 51.00 & 35.0 & 3.9\end{array}$

FFAACTION RELEÁSE DATA:

CESIUII-15i

\begin{tabular}{|c|c|c|c|c|c|}
\hline TIME & CFM & IFR & CFR & IFR, d & IRF, , 5 \\
\hline-0.0 & 4.3 & $7.49 E-0004$ & $7.49 E-0004$ & $8 . \overline{9 g E-\overline{0} D}$ & $1 . \dot{0} 4 E-0 \vec{v} 7$ \\
\hline 0.29 & 2.7 & $4.65 E-D Q 14$ & $1.22 \mathrm{E}-003$ & $2.25 E-0003$ & $2.51 E-008$ \\
\hline 1.00 & 5.4 & $9.36 E-D 04$ & $2.15 E-003$ & $1.32 E-003$ & $1.55 E-008$ \\
\hline 2.00 & 3.7 & E. $41 E-1004$ & $2.80 \mathrm{E}-003$ & 6. $41 E-1004$ & $7.42 E-009$ \\
\hline 3.00 & 3.1 & $5.42 \mathrm{E}-20 \mathrm{e} 4$ & $3.34 \mathrm{E}-0003$ & $5.42 E-0004$ & 6.28E-009 \\
\hline 4.00 & 2.7 & $4.70 E-E 04$ & $3.81 E-003$ & $4.70 E-004$ & $5.44 E-009$ \\
\hline 5.00 & 2.4 & $4.22 E-064$ & $4.23 \mathrm{E}-\hat{0} 03$ & $4.22 E-8004$ & $4.8 \mathrm{EE}-0009$ \\
\hline 18.00 & 29.5 & $5.15 E-063$ & $9.38 \mathrm{E}-063$ & $3.96 E-0 \overrightarrow{0} 4$ & $4.59 E-009$ \\
\hline 46.00 & 35.0 & $6.13 E-003$ & $1.55 E-002$ & $2.19 E-004$ & $2.53 E-009$ \\
\hline & 35.0 & $6.12 \mathrm{E}-0 \mathrm{E} 3$ & $2.16 E-\widehat{V} 02$ & $1.36 E-004$ & $57 E-$ \\
\hline
\end{tabular}

CUEATLT-EG

\begin{tabular}{|c|c|c|c|c|c|}
\hline TIME & $\mathrm{CPM}$ & IFR & CFR & IFR, $ם$ & IFR, 5 \\
\hline--- & -- & -- & --- & $\cdots-$ & $-\cdots$ \\
\hline 0.08 & 2.0 & $1.41 E-0004$ & $1.41 E-004$ & 1. $69 E-0005$ & $1.96 E-0 \bar{\theta} \theta$ \\
\hline 0.29 & $1 . \overline{0}$ & 6.79E-Uีणั5 & 2. $09 E-004$ & $3.26 E-\bar{E} \dot{a} 4$ & $3.78 E-009$ \\
\hline 1.000 & 1.4 & $9.33 E-065$ & $3.62 \mathrm{E}-004$ & $1.32 E-\ddot{\theta} 04$ & $1.52 E-009$ \\
\hline 2.000 & 1.8 & $1.22 E-0004$ & $4.24 E-6004$ & 1.22E-0004 & $1.41 E-\bar{\theta} \hat{\theta} \Xi$ \\
\hline 3.00 & 0.5 & $3.34 \mathrm{E}-06 \dot{5}$ & $4.59 E-004$ & $3.34 E-805$ & $3.87 E-0100$ \\
\hline 4.00 & 0.3 & $2.23 E-005$ & $4.86 \bar{E}-\overline{0} 0 \overline{4}$ & $2.23 \mathrm{E}-005$ & $2.59 E-010$ \\
\hline 5.000 & 0.6 & $4.33 \mathrm{E}-3065$ & $5.23 E-704$ & $4.30 E-0005$ & $4.9 E E-010$ \\
\hline 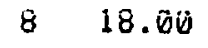 & 3.5 & $2.43 E-2104$ & $7.65 E-604$ & $1.87 E-0005$ & $2.16 E-010$ \\
\hline 46.00 & 5.2 & $3.59 E-6004$ & 1. $13 E-\ddot{6} 63$ & $1.2 \overline{8 E-v 05}$ & $1.4 \mathrm{GE}-010$ \\
\hline 91.00 & 3.9 & $2.67 E-0004$ & $1: 39 E-6003$ & $5.54 E-006$ & $6.87 E-011$ \\
\hline
\end{tabular}


Table C-2

25 wt\% Sodium Sulfate in Modified Sulfur Cement

FILE: $\quad 85-8-2$

STOFEO ON DISE: PK DI

85-5 LEACHATE CGUUNTING UÁtA (CFM):

$\begin{array}{rrrr}I & T I Y U E & C 5 & C O \\ 1 & 0.08 & 7.6 & 1.8 \\ 2 & 0.25 & 5.6 & 1.8 \\ 3 & 1.000 & 10.1 & 1.8 \\ 4 & 2.000 & 8.5 & 3.7 \\ 5 & 3.00 & 7.2 & 1.2 \\ 6 & 4.00 & 5.1 & 0.7 \\ 7 & 5.00 & 5.2 & 1.2 \\ 8 & 18.00 & 34.5 & 6.7 \\ 5 & 46.000 & 44.0 & 5.6 \\ 10 & 91.00 & 33.0 & 5.4\end{array}$

FRACTIDIN RELEASE DATÁ:

CESIUM- 137

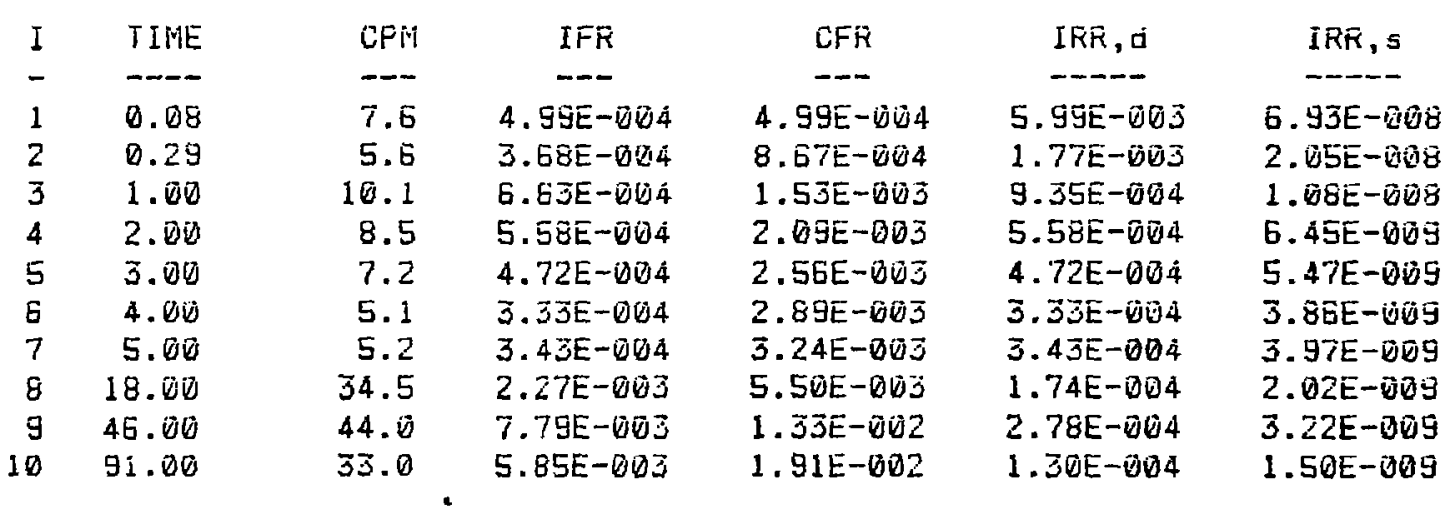

\section{COBÄLT EO}

\begin{tabular}{|c|c|c|c|c|c|c|}
\hline I & TIME & CFM & IFR & CFR & IRR, d & IRR, 5 \\
\hline - & -- & $\cdots$ & -- & -- & $-\infty$ & \\
\hline 1 & 0.08 & 1.8 & $1.18 \mathrm{E}-0004$ & $1.18 E-D 04$ & $1.42 E-003$ & 1.64E- \\
\hline 2 & 0.29 & 1.8 & $1.16 E-004$ & $2.34 E-6044$ & $5.59 E-004$ & $6.47 E-009$ \\
\hline 3 & 1.00 & 1.8 & $1.16 E-004$ & $3.51 E-D D 4$ & $1.64 E-3004$ & 1. $900 \mathrm{E}-\dot{0} \mathrm{Q} \mathrm{g}$ \\
\hline 4 & 2.60 & 3.7 & $2.36 E-804$ & $5.87 E-004$ & $2.36 E-004$ & $2.73 E-009$ \\
\hline 5 & 3.60 & 1.2 & $7.37 E-005$ & $6.61 E-064$ & $7.37 E-005$ & $8.54 E-010$ \\
\hline 6 & $4.0 \overline{0}$ & 0.7 & $4.60 E-005$ & $7.07 \mathrm{E}-004$ & 4. $60 E-005$ & $5.32 E-616$ \\
\hline 7 & $5.0 \overline{0}$ & 1.2 & $7.39 E-005$ & $7.81 \mathrm{E}-004$ & 7.3 SE- 0005 & $8.55 E-010$ \\
\hline 8 & 18.60 & 6.7 & $4.28 E-004$ & $1.21 E-003$ & $3.29 E-005$ & $3.81 E-010$ \\
\hline g & 46.00 & 5.6 & $3.89 E-004$ & $1.60 E-005$ & $1.39 E-205$ & $1.61 E-010$ \\
\hline 10 & 91.00 & 5.4 & $3.80 E-004$ & $1.98 \mathrm{E}-00 \mathrm{~J}$ & $8.45 E-0005$ & $9.78 E-011$ \\
\hline
\end{tabular}




\section{Table $\mathrm{C}-3$}

\section{Wt\% Sodium Sulfate in Modified Sulfur Cement}

\begin{tabular}{|c|c|c|c|}
\hline $85-5$ & LEACHATE & COUNTI ING & DATA (CFII) \\
\hline$I$ & TIME & CS & 00 \\
\hline 1 & $0 \overline{00}$ & 32.2 & 10.6 \\
\hline$\therefore$ & 0.29 & 51.2 & 9.5 \\
\hline $\bar{j}$ & 1.00 & 86.5 & 14.5 \\
\hline 4 & 2.000 & 38.7 & 38.5 \\
\hline 5 & 3.00 & 14.5 & 4.3 \\
\hline $\bar{E}$ & 4.00 & 43.2 & 4.9 \\
\hline 7 & 5.00 & 23.7 & 11.5 \\
\hline 8 & 18.00 & 422.5 & 355.5 \\
\hline$\overline{9}$ & 46.00 & 365.9 & 159.5 \\
\hline 10 & 91.00 & 518.3 & $6 \overline{37.2}$ \\
\hline
\end{tabular}

FRACTION RELEASE OATA:

CESIUYT-137

\begin{tabular}{|c|c|c|c|c|c|}
\hline TIME & CPin & IFR & CFR & IRR, d & IRR , 5 \\
\hline---- & --- & --- & --- & ----- & ----- \\
\hline 0.08 & 32.2 & $1.32 E-003$ & $1.32 E-003$ & $1.58 E-002$ & 1. $.85 \vec{E}-007$ \\
\hline 0.29 & 51.2 & $2.10 E-\square 0 \overline{3}$ & $3.4 I E-003$ & $1.01 E-002$ & I. 16E-007 \\
\hline $1 . \bar{\nabla} 0$ & 86.5 & $3.54 E-603$ & E. $96 E-00 \overline{3}$ & $5.00 E-0003$ & $5.79 E-1008$ \\
\hline 2.00 & 58.7 & $1.58 E-003$ & $8.54 E-003$ & $1.58 \mathrm{E}-0 \overline{0} \mathrm{~S}$ & 1. $85 E-00 B$ \\
\hline 3.00 & 14.9 & 6. $0 E E-004$ & $9.15 E-003$ & G. $0 E E-D 04$ & $7.04 E-00 \overline{9}$ \\
\hline 4.00 & 43.2 & $1.77 E-003$ & 1. . $95-002$ & $1.77 \mathrm{E}-0003$ & 2.05E-00ิ8 \\
\hline 5.00 & 23.7 & $9.69 E-004$ & 1.19E-002 & $9.69 E-004$ & $1.12 E-008$ \\
\hline 18.00 & 422.5 & $1.73 E-002$ & $2.92 E-002$ & $1.33 E-003$ & $1.54 E-008$ \\
\hline 46.00 & 365.9 & $3.79 E-002$ & $6.70 E-002$ & 1. $35 E-003$ & $1.56 E-008$ \\
\hline 91.00 & 518.9 & $5.37 E-0 C 2$ & $1.21 E-001$ & $1.19 E-003$ & 1.38E-008 \\
\hline
\end{tabular}

\section{COBÄLT-60}

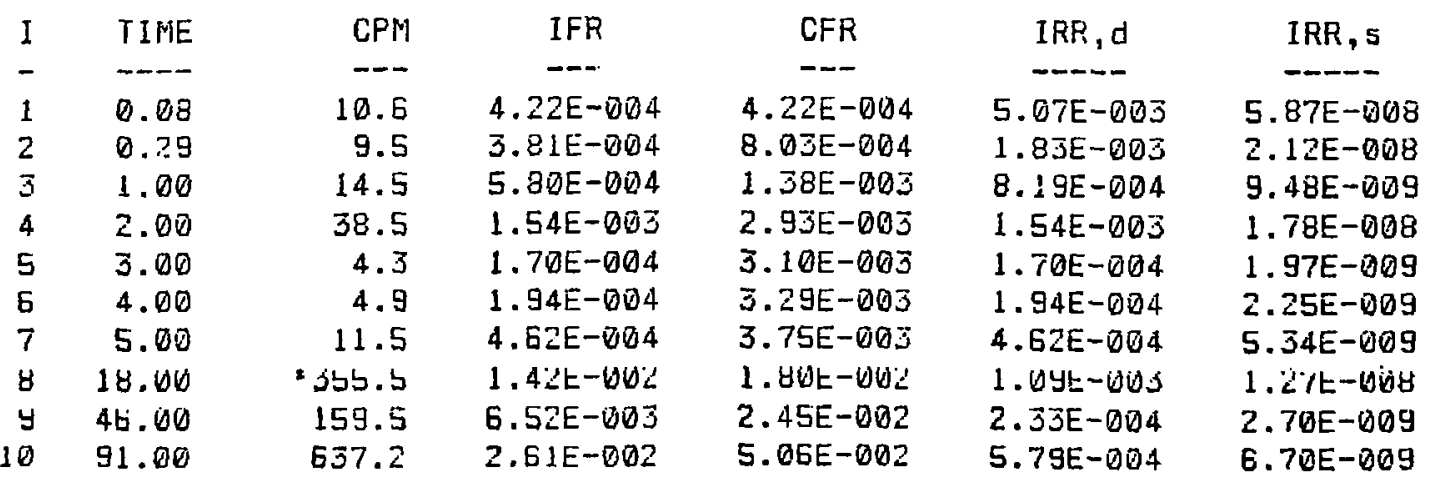




\section{Table C-4}

\section{Wt\% Sodium SuTfate in Modified SuTfur Cement}

FILE: $\quad 85-8-4$

STORED ON DISC: PK DI

85-5 LEACHATE COUNTING DATA (CPM):

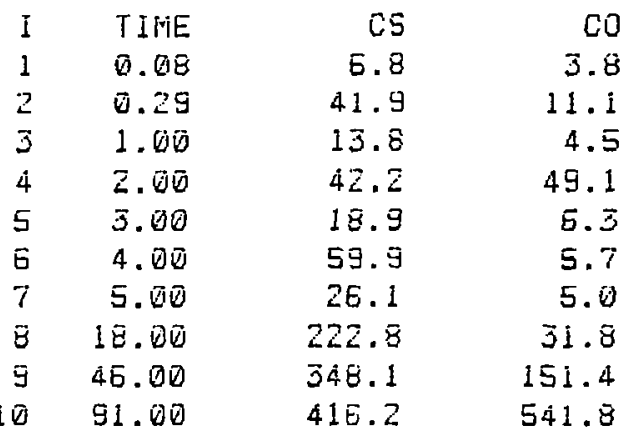

FRACTION RELEASE DATA:

\section{CESIUM-137}

\begin{tabular}{|c|c|c|c|c|c|}
\hline TIME & CPM & IFR & CFR & IRR, d & IRf , s \\
\hline-- & -- & -- & -- & $-\infty-$ & \\
\hline 0.08 & 6.8 & $2.86 E-D 04$ & $2.86 E-004$ & $3.44 E-003$ & $3.58 E-600$ \\
\hline 0.29 & 41.9 & $1.77 E-1003$ & $2.08 E-003$ & $8.52 E-003$ & $9.86 E-008$ \\
\hline 1.00 & 13.8 & $5.82 E-004$ & $2.64 E-003$ & $8.22 E-004$ & $9.51 E-005$ \\
\hline 2.00 & 42.2 & $1.79 E-003$ & $4.43 E-003$ & 1.79E- 005 & $2.07 E-000$ \\
\hline 3.00 & 18.9 & $7.99 E-004$ & $5.23 \mathrm{E}-003$ & $7.99 E-004$ & $9.24 E-009$ \\
\hline 4.00 & 59.9 & $2.54 E-003$ & $7.76 E-003$ & $2.54 E-003$ & $2 . \overline{9} 4 E-008$ \\
\hline 5.00 & 26.1 & $1.10 \mathrm{E}-003$ & $8.87 E-003$ & $1.10 E-003$ & $1.28 E-0 D 8$ \\
\hline 18.66 & 222.8 & Y. $4 S E-U W S$ & 1. $85 E-662$ & $7.25 E-004$ & $8.40 E-009$ \\
\hline $4 b .00$ & 348.1 & $5.13 t-v 62$ & b.bbt-bb2 & 1. j3t-6us & $1.34 t-0 B E$ \\
\hline 41.606 & 416.2 & $4.4 b t-6 b 2$ & 1. & 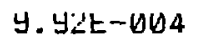 & 1.13t-068 \\
\hline
\end{tabular}

\section{CUUEALI-GE}

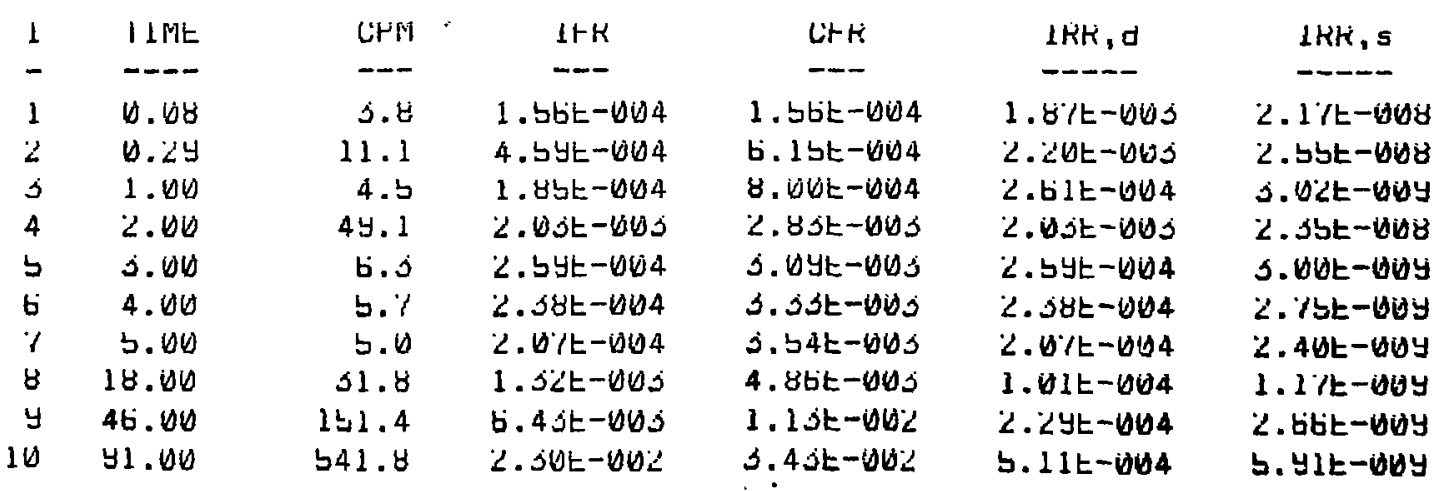




\section{Table C-5}

\section{Wt\% Incinerator Ash in Modified Sulfur Cement}

FILE: $\quad 35.5 .5$

STORED ON DISC: PK D1

O5-5 LENCHATE COUNTING DATA (CPM):

$\begin{array}{rrrr}\text { I } & \text { TIML } & \text { CS } & C 0 \\ 1 & 0.00 & 5.7 & 0.0 \\ 2 & 0.23 & 4.5 & 0.0 \\ 3 & 1.00 & 6.7 & 0.1 \\ 4 & 2.00 & 5.4 & 0.1 \\ 5 & 3.00 & 4.9 & 0.1 \\ 6 & 4.00 & 3.9 & 0.1 \\ 7 & 5.00 & 3.8 & 1.3 \\ 0 & 10.00 & 7.9 & 1.0 \\ 3 & 46.00 & 21.3 & 0.1 \\ 10 & 31.00 & 18.9 & 0.3\end{array}$

FRACTION RELEASE DATA:

CESIUM- 137

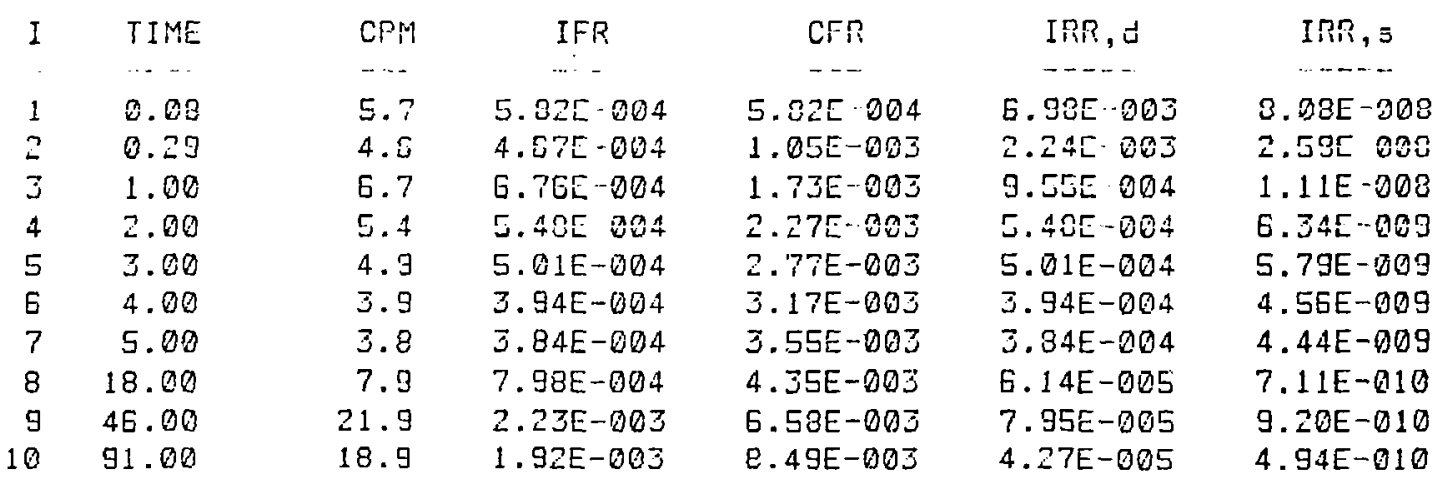

COBALT-G0

\begin{tabular}{|c|c|c|c|c|c|}
\hline TIME & CPM & IFR & CFR & IRR,d & IRR, 5 \\
\hline$\cdots$ & $-\cdots$ & $-\infty$ & --- & $-\cdots$ & \\
\hline 0.08 & 0.0 & $3.28 E-006$ & $3.28 \mathrm{E}-006$ & $3.94 \mathrm{E}-005$ & $4.56 E-010$ \\
\hline 0.29 & 0.0 & $0.00 E+000$ & $3.285-006$ & $0.00 E+000$ & $0.00 \mathrm{E}+000$ \\
\hline 1.00 & 0.1 & $6.56 E-006$ & $9.84 E-006$ & $9.26 E-006$ & $1.07 E-010$ \\
\hline 2.00 & 0.1 & 6.56E-006 & $1.64 E-005$ & $5.56 E-006$ & $7.59 E-011$ \\
\hline 3.00 & 0.1 & $8.20 E-006$ & $2.46 E-005$ & $3.20 E-006$ & $9.49 E-011$ \\
\hline 4.00 & 0.1 & 1.15E-605 & $3.61 E-005$ & $1.15 \mathrm{E}-005$ & $1.33 \mathrm{E}-010$ \\
\hline 5.00 & 1.3 & $1.28 E-004$ & $1.54 \mathrm{E}-004$ & $1.28 \mathrm{E}-004$ & $1.48 E-009$ \\
\hline 18.00 & 1.6 & 1.52E-004 & $3.16 E-004$ & $1.17 E-005$ & $1.36 E-010$ \\
\hline 46.00 & 0.1 & $9.84 E-006$ & $3.26 E-004$ & $3.51 E-007$ & $4.07 E-012$ \\
\hline 91.00 & 0.3 & $2.79 E-005$ & $3.54 E-004$ & $20 ?$ & -01 \\
\hline
\end{tabular}




\section{Wt\% Incinerator Ash in Modified Sulfur Cement}

FILE: $\quad 85-5-6$

STORED ON DISC: PK DI

85-5 LEACHATE COUNTING DATA (CPM):

$\begin{array}{rrrr}I & \text { TIME } & C S & C D \\ 1 & 0.08 & 3.4 & 0.2 \\ 2 & 0.29 & 2.3 & 0.1 \\ 3 & 1.00 & 3.4 & 0.0 \\ 4 & 2.00 & 3.0 & 0.2 \\ 5 & 3.00 & 1.7 & 0.1 \\ 6 & 4.00 & 1.6 & 0.2 \\ 7 & 5.00 & 1.4 & 1.3 \\ 8 & 18.00 & 21.3 & 0.5 \\ 9 & 46.00 & 7.4 & 2.1 \\ 10 & 91.00 & 5.7 & 0.5\end{array}$

FRACTION RELEASE DATA:

\section{CESIUM-13?}

\begin{tabular}{|c|c|c|c|c|c|}
\hline TIME & CPM & IFR & CFR & IPR, d & IRR, 5 \\
\hline$\cdots$ & $\cdots$ & $-\infty$ & $\cdots$ & $\cdots-$ & $\cdots-$ \\
\hline 0.08 & 3.4 & $2.97 E-00.4$ & $2.57 E-004$ & $3.57 E-003$ & $4.13 E-008$ \\
\hline 0.29 & 2.3 & $2.03 E-004$ & $5.00 E-004$ & $9.74 E-004$ & $1.13 E-008$ \\
\hline 1.00 & 3.4 & $2.93 E-004$ & $7.93 E-004$ & $4.13 E-004$ & $4.78 E-989$ \\
\hline 2.00 & 3.0 & $2.51 E-004$ & $1.05 E-003$ & $2.61 F-004$ & $3.02 \mathrm{E}-009$ \\
\hline 3.00 & 1.7 & $1.51 E-004$ & $1.20 E-003$ & $1.51 E-004$ & $1.74 \mathrm{E}-00 \mathrm{~S}$ \\
\hline 4.00 & 1.6 & $1.42 E-004$ & $1.35 E-003$ & $1.42 E-004$ & $1.54 E-00$ \\
\hline 5.00 & 1.4 & $1.23 E-004$ & $1.47 E-003$ & $1.23 \mathrm{E}-0004$ & $1.43 E-609$ \\
\hline 18.00 & 21.3 & $1.85 E-003$ & $3.32 E-003$ & $1.4 \mathrm{JE}-004$ & $1.65 E-00$ \\
\hline 46.00 & 7.4 & $6.43 E-004$ & $3.97 E-003$ & $2.30 E-005$ & 2.EGE-O. \\
\hline 19 & 5.7 & $4.93 E-004$ & $4.46 E-003$ & $1.09 E-005$ & 1 \\
\hline
\end{tabular}

COBALT $-5 O$

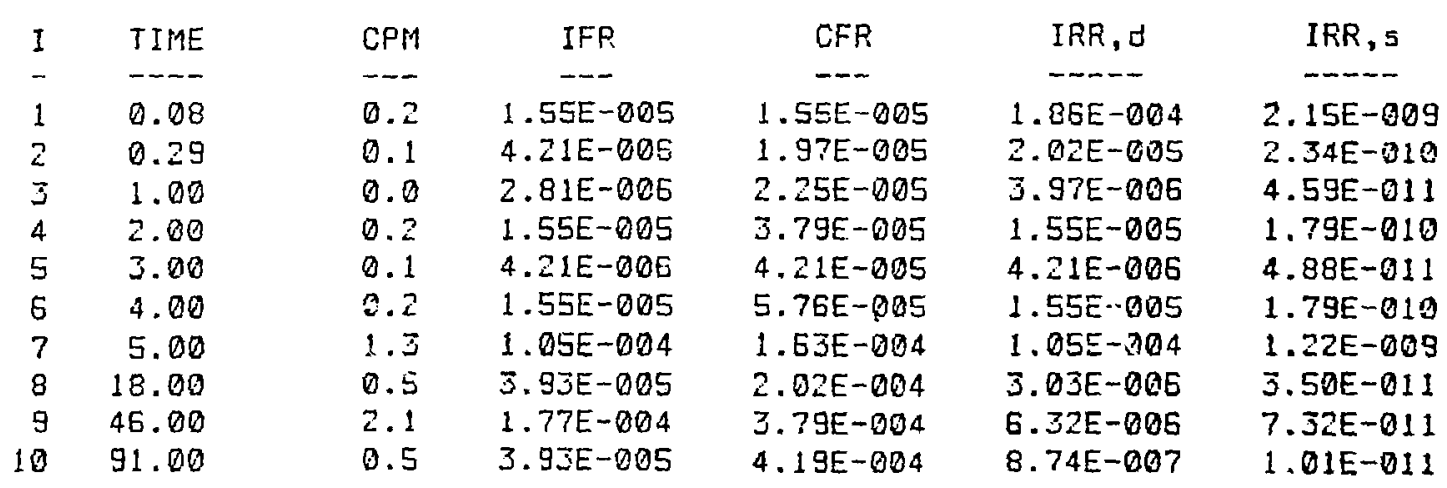


Table C-7

\section{Wt\% Incinerator Ash in Modified Sulfur Cement}

FILE : $\quad 85-5-7$

STORED ON DISC: PK 01

85-5 LEACHATE COUNTING DATA (CPM):

$\begin{array}{rrrr}\text { I } & \text { TIME } & \text { CS } & \text { CO } \\ 1 & 0.00 & 4.5 & 0.0 \\ 2 & 0.29 & 6.2 & 0.2 \\ 3 & 1.00 & 12.9 & 0.2 \\ 4 & 2.00 & 10.9 & 0.3 \\ 5 & 3.00 & 8.0 & 0.2 \\ 6 & 4.00 & 7.1 & 0.2 \\ 7 & 5.00 & 8.3 & 3.1 \\ 8 & 18.00 & 44.0 & 0.6 \\ 9 & 46.00 & 41.3 & 0.4 \\ 10 & 91.00 & 35.6 & 0.1\end{array}$

FRACTION RELEASE DATA:

\begin{tabular}{|c|c|c|c|c|c|c|}
\hline I & TIME & CPM & IFR & CFP & IFR, $d$ & IRF, $\mathbf{s}$ \\
\hline- & --- & -- & -- & $-\cdots$ & $\cdots-$ & $\cdots-$ \\
\hline 1 & 0.08 & 4.5 & 1.76E-004 & $1.75 E-004$ & $2.11 \mathrm{E}-003$ & $2.44 E-008$ \\
\hline 2 & 0.29 & 5.2 & $2.41 E-004$ & $4.17 \mathrm{E}-004$ & 1. $16 \mathrm{E}-00 \mathrm{~S}$ & $1.34 \mathrm{E}-008$ \\
\hline 3 & 1.00 & 12.9 & 4. 99E-004 & $9.16 E-0 D 4$ & $7.05 E-004$ & 8.16E-009 \\
\hline 4 & 2.00 & 10.9 & $4.24 E-004$ & $1.34 E-003$ & $4.24 E-004$ & $4.90 E-009$ \\
\hline 5 & 3.00 & 8.0 & $3.11 E-004$ & $1.55 E-0003$ & $3.11 E-004$ & $3.60 E-009$ \\
\hline 5 & 4.00 & 7.1 & $2.75 E-004$ & $1.93 E-003$ & $2.75 E-004$ & $3.18 E-009$ \\
\hline 7 & 5.00 & 8.3 & $3.22 E-004$ & $2.25 E-003$ & $3.22 E-004$ & $3.72 \mathrm{E}-009$ \\
\hline 8 & 18.00 & 44.0 & $1.71 E-003$ & $3.96 \mathrm{E}-003$ & $1.31 E-004$ & $1.52 \mathrm{E}-009$ \\
\hline 9 & 46.00 & 41.3 & $1.60 E-003$ & $5.56 \mathrm{E}-003$ & $5.73 E-005$ & $6.63 E-010$ \\
\hline 10 & 91.00 & 35.6 & $1.38 E-003$ & $6.94 E-003$ & $3.07 E-005$ & $3.55 E-010$ \\
\hline
\end{tabular}

COBALT -60

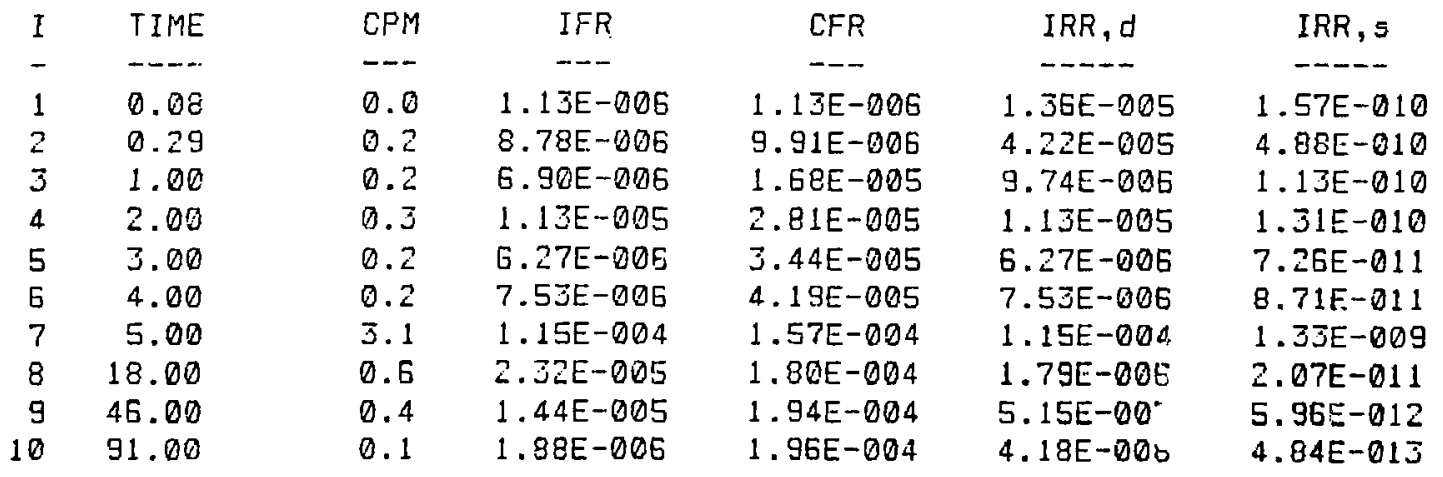




\section{Table $\mathbf{C}-8$}

\section{Wt\% Incinerator Ash in Modified Sulfur Cement}

FILE: $85-5-8$
STORED ON DISC: PK D1

85-5 LEACHATE COUNTING DATA (CPM):

$\begin{array}{rrrr}\text { I } & \text { TIME } & C S & C 0 \\ 1 & 0.08 & 5.9 & 0.1 \\ 2 & 0.29 & 6.3 & 0.1 \\ 3 & 1.00 & 13.7 & 0.3 \\ 4 & 2.00 & 11.3 & 0.3 \\ 5 & 3.00 & 8.7 & 0.2 \\ 6 & 4.00 & 5.7 & 0.1 \\ 7 & 5.00 & 5.8 & 1.7 \\ 8 & 18.00 & 36.9 & 0.3 \\ 9 & 46.00 & 36.3 & 0.3 \\ 10 & 91.00 & 31.7 & 0.1\end{array}$

FRACTION RELEASE DATA:

CESIUI1-1 37

\begin{tabular}{|c|c|c|c|c|c|}
\hline TIME & CPM & IFR & CFR & IRR, d & IRR, 5 \\
\hline$-\infty$ & -- & $-\cdots$ & --- & $\ldots-$ & $-\cdots$ \\
\hline 0.08 & 5.9 & $2.34 \mathrm{E}-004$ & $2.34 E-D 04$ & $2.81 E-003$ & $3.25 E-008$ \\
\hline 0.29 & 6.3 & $2.49 E-004$ & $4.83 E-004$ & $1.20 \mathrm{E}-003$ & $1.38 \mathrm{E}-008$ \\
\hline 1.00 & 13.7 & $5.45 E-004$ & $1.03 E-003$ & $7.70 \mathrm{E}-004$ & $8.91 E-009$ \\
\hline 2.00 & 11.3 & $4.49 E-004$ & $1.48 \mathrm{E}-0.03$ & $4.45 E-004$ & $5.20 E-309$ \\
\hline 3.00 & 8.7 & $3.44 E-004$ & $1.82 E-003$ & $3.44 E-004$ & $3.98 E-009$ \\
\hline 4.60 & 5.7 & $2.25 E-004$ & $2.05 E-003$ & $2.25 E-004$ & $2.61 E-009$ \\
\hline 5.00 & 5.8 & $2.29 E-004$ & $2.28 \mathrm{E}-003$ & $2.29 E-004$ & $2.65 E-009$ \\
\hline 18.00 & 36.9 & $1.47 \mathrm{E}-003$ & $3.74 \mathrm{E}-003$ & $1.13 E-004$ & $1.30 \mathrm{E}-009$ \\
\hline 46.00 & 36.3 & $1.44 E-003$ & $5.18 E-003$ & $5.15 E-005$ & $5.96 E-010$ \\
\hline 91.00 & 31.7 & $1.26 E-003$ & $6.44 \mathrm{E}-003$ & $2.80 E-005$ & $3.245-010$ \\
\hline
\end{tabular}

COBALT-ED

$\begin{array}{rr}1 & T I M \\ 1 & 0.00 \\ 2 & 0.2 \\ 3 & 1.00 \\ 4 & 2.00 \\ 5 & 3.00 \\ 6 & 4.00 \\ 7 & 5.00 \\ 8 & 18.00 \\ 3 & 46.00 \\ 10 & 91.00\end{array}$

\begin{tabular}{|c|c|c|}
\hline CPM & IFR & CFR \\
\hline-- & --- & $\cdots$ \\
\hline 0.1 & $3.07 E-00 \mathrm{E}$ & $3.07 \mathrm{E}-00$ \\
\hline 0.1 & $3.85 E-006$ & $6.92 E-006$ \\
\hline 0.3 & $1.03 E-005$ & $1.72 E-005$ \\
\hline .3 & $1.28 \mathrm{E}-005$ & $3.00 \mathrm{E}-005$ \\
\hline .2 & 5. $42 \mathrm{E}-00 \mathrm{E}$ & $3.65 \mathrm{E}-005$ \\
\hline .1 & $5.14 \mathrm{E}-006$ & $4.16 E-005$ \\
\hline 1.7 & $6.49 \mathrm{E}-005$ & $1.05 E-004$ \\
\hline .3 & $1.09 \mathrm{E}-005$ & $1.17 \mathrm{E}-\emptyset 04$ \\
\hline 3 & $9.63 E-006$ & $1.27 E-004$ \\
\hline & $-\infty 06$ & $1.30 \mathrm{E}$ \\
\hline
\end{tabular}
IRR, 5
4.27E-010
2.14E- 010
1. $.68 E-010$
1. $49 E-010$
7.4JE-011
5. 95E-011
$7.51 E-010$
9.72E-0.12
$3.98 E-012$
8. $26 E-013$ 
Table C-9

Modified Sulfur Cement Waste Form Leaching Specimen Data

\begin{tabular}{|c|c|c|c|c|c|c|c|}
\hline \multirow[b]{2}{*}{ File No. } & \multicolumn{2}{|c|}{$137 \mathrm{Cs}$} & \multicolumn{2}{|c|}{$60_{\mathrm{Co}}$} & \multirow[b]{2}{*}{$\begin{array}{l}\text { Waste } \\
\text { Form } \\
\text { Volume, } \mathrm{cm}^{3}\end{array}$} & \multirow[b]{2}{*}{$\begin{array}{l}\text { Surface } \\
\text { Area, } \operatorname{cin}^{2}\end{array}$} & \multirow[b]{2}{*}{$\begin{array}{l}\text { Leachant } \\
\text { Vol ume, inl }\end{array}$} \\
\hline & Activity, $\mu \mathrm{Ci}$ & $\begin{array}{l}\text { Equivalent } \\
\text { Counts, CPM }\end{array}$ & Activity, ${ }_{\mu} \mathrm{Ci}$ & $\begin{array}{l}\text { Equivalent } \\
\text { Counts, CPM }\end{array}$ & & & \\
\hline $85-5-1$ & 21.97 & 203906 & 23.44 & 210272 & $14 \wedge .5$ & 157.9 & 1579 \\
\hline $85-5-2$ & 23.96 & 222376 & 25.56 & 229290 & 161.3 & 172.2 & 1720 \\
\hline $85-5-3$ & 43.76 & 406142 & 46.70 & 418929 & 154.7 & 166.6 & 1666 \\
\hline $85-5-4$ & 43.52 & 403915 & 46.44 & 416597 & 154.3 & 166.2 & 1662 \\
\hline $85-5-5$ & 16.66 & 154623 & 17.78 & 159498 & 142.3 & 156.9 & 1569 \\
\hline $85-5-6$ & 18.22 & 169102 & 19.44 & 174389 & 131.2 & 147.0 & 1470 \\
\hline $85-5-7$ & 44.66 & 414495 & 47.66 & 427541 & 152.3 & 160.9 & 1609 \\
\hline $85-5-8$ & 44.65 & 414402 & 47.64 & 427362 & 152.5 & 164.7 & 1647 \\
\hline
\end{tabular}


Table C-10

\section{Average Cumulative Releases, 20 wt\% Sodium Sulfate in Modified Sulfur Cement}

FILE : 20SULF

STORED ON DISC: PK D1

CUMULATIUE FRACTION RELEASE, Cs:

$\begin{array}{rrrcc}\text { I } & \text { TIME } & 85-5-1 & 85-5-2 & \text { AUG } \\ 1 & 0.08 & 4.83 \mathrm{E}-003 & 3.43 \mathrm{E}-003 & 4.13 \mathrm{E}-003 \\ 2 & 0.29 & 5.39 \mathrm{E}-003 & 5.35 \mathrm{E}-003 & 5.37 \mathrm{E}-003 \\ 3 & 1.00 & 6.35 \mathrm{E}-003 & 7.71 \mathrm{E}-003 & 7.03 \mathrm{E}-003 \\ 4 & 2.00 & 7.44 \mathrm{E}-003 & 1.01 \mathrm{E}-002 & 8.79 \mathrm{E}-003 \\ 5 & 3.00 & 9.15 \mathrm{E}-003 & 1.13 \mathrm{E}-002 & 1.02 \mathrm{E}-002 \\ 6 & 4.00 & 1.06 \mathrm{E}-002 & 1.29 \mathrm{E}-002 & 1.18 \mathrm{E}-002 \\ 7 & 5.00 & 1.20 \mathrm{E}-002 & 1.46 \mathrm{E}-002 & 1.33 \mathrm{E}-002 \\ 8 & 18.00 & 2.73 \mathrm{E}-002 & 2.47 \mathrm{E}-002 & 2.00 \mathrm{E}-002 \\ 9 & 46.00 & 5.33 \mathrm{E}-002 & 4.35 \mathrm{E}-002 & 4.84 \mathrm{E}-002 \\ 0 & 91.00 & 7.42 \mathrm{E}-002 & 5.37 \mathrm{E}-002 & 5.90 \mathrm{E}-002\end{array}$

CUMULATIUE FRACTION RELEASE, CO:

$\begin{array}{rrccc}\text { I } & \text { TIME } & 85-5-1 & 85-5-2 & \text { AUG } \\ 1 & 0.08 & 1.68 E-003 & 1.19 \mathrm{E}-003 & 1.44 \mathrm{E}-003 \\ 2 & 0.29 & 1.78 \mathrm{E}-003 & 1.5 \mathrm{EE}-003 & 1.67 \mathrm{E}-003 \\ 3 & 1.00 & 1.90 \mathrm{E}-003 & 1.86 \mathrm{E}-003 & 1.88 \mathrm{E}-003 \\ 4 & 2.00 & 1.97 \mathrm{E}-003 & 2.07 \mathrm{E}-003 & 2.02 \mathrm{E}-003 \\ 5 & 3.00 & 2.08 \mathrm{E}-003 & 2.15 \mathrm{E}-003 & 2.11 \mathrm{E}-003 \\ 6 & 4.00 & 2.17 \mathrm{E}-003 & 2.24 \mathrm{E}-003 & 2.20 \mathrm{E}-003 \\ 7 & 5.00 & 2.28 \mathrm{E}-003 & 2.36 \mathrm{E}-003 & 2.32 \mathrm{E}-003 \\ 8 & 18.00 & 2.89 \mathrm{E}-003 & 2.74 \mathrm{E}-003 & 2.81 \mathrm{E}-003 \\ 9 & 46.00 & 3.74 \mathrm{E}-003 & 3.45 \mathrm{E}-003 & 3.60 \mathrm{E}-003 \\ 10 & 91.00 & 4.41 \mathrm{E}-003 & 4.57 \mathrm{E}-003 & 4.49 \mathrm{E}-003\end{array}$


Table $C-11$

Average Cumulative Releases, 40 Wt\% Sodium Sulfate in Modified Sulfur Cement

FILE : $40 \subseteq U L F$

STGREO ON DISC: PK DI

CUMULATIUE FFACTION RELEASE, Cs:

$\begin{array}{rrrcc}I & \text { TIME } & 85-5-3 & 85-5-4 & \text { AUG } \\ 1 & 0.08 & 1.39 E-003 & 8.15 \mathrm{E}-004 & 1.10 \mathrm{E}-003 \\ 2 & 0.29 & 2.82 \mathrm{E}-003 & 1.67 \mathrm{E}-003 & 2.25 \mathrm{E}-003 \\ 3 & 1.00 & 5.64 \mathrm{E}-003 & 2.40 \mathrm{E}-003 & 4.02 \mathrm{E}-003 \\ 4 & 2.00 & 6.68 \mathrm{E}-003 & 3.90 \mathrm{E}-003 & 5.25 \mathrm{E}-003 \\ 5 & 3.00 & 7.81 \mathrm{E}-003 & 4.87 \mathrm{E}-003 & 6.34 \mathrm{E}-003 \\ 6 & 4.00 & 8.99 \mathrm{E}-003 & 5.82 \mathrm{E}-003 & 7.41 \mathrm{E}-003 \\ 7 & 5.00 & 1.00 \mathrm{E}-002 & 7.03 \mathrm{E}-003 & 8.53 \mathrm{E}-003 \\ 8 & 18.00 & 2.41 \mathrm{E}-002 & 1.79 \mathrm{E}-002 & 2.10 \mathrm{E}-002 \\ 9 & 46.00 & 5.45 \mathrm{E}-002 & 5.49 \mathrm{E}-002 & 5.47 \mathrm{E}-002 \\ 10 & 91.00 & 1.54 \mathrm{E}-001 & 1.62 \mathrm{E}-001 & 1.58 \mathrm{E}-001\end{array}$

CUMULATIUE FrACTION RELEASE, CO:

$\begin{array}{rcccc}I & \text { TIME } & 85-5-3 & 85-5-4 & \text { AUG } \\ 1 & 0.08 & 2.55 E-004 & 1.42 \mathrm{E}-004 & 2.04 \mathrm{E}-004 \\ 2 & 0.29 & 3.10 \mathrm{E}-004 & 1.95 \mathrm{E}-004 & 2.53 \mathrm{E}-004 \\ 3 & 1.00 & 4.09 \mathrm{E}-004 & 2.15 \mathrm{E}-004 & 3.14 \mathrm{E}-004 \\ 4 & 2.00 & 4.58 \mathrm{E}-004 & 2.61 \mathrm{E}-004 & 3.59 \mathrm{E}-004 \\ 5 & 3.00 & 5.02 \mathrm{E}-004 & 2.85 \mathrm{E}-004 & 3.93 \mathrm{E}-004 \\ 6 & 4.00 & 5.30 \mathrm{E}-004 & 3.05 \mathrm{E}-004 & 4.21 \mathrm{E}-004 \\ 7 & 5.00 & 5.64 \mathrm{E}-004 & 3.34 \mathrm{E}-004 & 4.49 \mathrm{E}-004 \\ 8 & 18.00 & 9.13 \mathrm{E}-004 & 4.77 \mathrm{E}-004 & 6.95 \mathrm{E}-004 \\ 9 & 46.00 & 1.51 \mathrm{E}-003 & 6.61 \mathrm{E}-004 & 1.08 \mathrm{E}-003 \\ 10 & 91.00 & 2.40 \mathrm{E}-003 & 9.36 \mathrm{E}-004 & 1.67 \mathrm{E}-003\end{array}$


Table C-12

Average Cumulative Releases, $20 \mathrm{Wt} \%$ Incinerator Ash in

\begin{tabular}{|c|c|c|c|c|}
\hline \multicolumn{2}{|c|}{ CUMUULATIUE } & \multicolumn{3}{|c|}{ FRACTION RELEASE, Cs: } \\
\hline I & TIME & $85-5-5$ & $85-5-6$ & AUG \\
\hline 1 & 0.08 & $5.82 E-004$ & $2.97 E-004$ & $4.39 E-004$ \\
\hline 2 & 0.29 & 1.05E-003 & $5.00 E-004$ & $7.74 E-004$ \\
\hline 3 & 1.00 & $1.73 \mathrm{E}-903$ & $7.93 E-004$ & 1.26E-003 \\
\hline 4 & 2.00 & $2.27 E-003$ & $1.05 \mathrm{E}-003$ & $1.66 E-003$ \\
\hline 5 & 3.00 & $2.77 E-003$ & $1.20 E-003$ & 1.99E-003 \\
\hline$\theta$ & 4.90 & $3.17 E-005$ & $1.35 E-003$ & $2.26 E-003$ \\
\hline 7 & 5.00 & $3.55 E-003$ & $1.47 E-003$ & $2.51 \mathrm{E}-003$ \\
\hline 8 & 18.00 & $4.35 E-003$ & $3.32 \mathrm{E}-003$ & $3.84 E-003$ \\
\hline 9 & 46.00 & E. $58 E-003$ & $3.97 E-003$ & $5.27 E-003$ \\
\hline a & 91.00 & $8.49 E-003$ & 4. $46 E-003$ & $6.48 E-003$ \\
\hline
\end{tabular}

CUMULATIUE FRACTION RELEASE, CO:

$\begin{array}{rrccc}I & \text { TIME } & 85-5-5 & 85-5-6 & \text { AVG } \\ 1 & 0.00 & 3.28 E-006 & 1.55 E-005 & 9.37 E-006 \\ 2 & 0.29 & 3.28 E-006 & 1.97 E-005 & 1.1 .5 E-005 \\ 3 & 1.00 & 9.84 E-006 & 2.25 E-005 & 1.62 E-005 \\ 4 & 2.00 & 1.64 E-005 & 3.79 E-005 & 2.72 E-005 \\ 5 & 3.00 & 2.46 E-005 & 4.21 E-005 & 3.34 E-005 \\ 6 & 4.00 & 3.61 E-005 & 5.76 E-005 & 4.68 E-005 \\ 7 & 5.00 & 1.64 E-004 & 1.63 E-004 & 1.63 E-004 \\ 8 & 18.00 & 3.16 E-004 & 2.02 E-004 & 2.59 E-004 \\ 9 & 46.00 & 3.25 E-004 & 3.79 E-004 & 3.53 E-004 \\ 0 & 91.00 & 3.54 E-004 & 4.19 E-004 & 3.86 E-004\end{array}$


Table C-13

Average Cumulative Releases, $40 \mathrm{Wt} \%$ Incinerator Ash

\begin{tabular}{|c|c|c|c|c|}
\hline \multicolumn{5}{|c|}{ CUMULATIUE FRACTION RELEASE, C5: } \\
\hline I & TIME & $85-5-7$ & $85-5-8$ & AUG \\
\hline 1 & 0.08 & $1.76 E-004$ & $2.34 E-004$ & $2.05 E-004$ \\
\hline 2 & 0.29 & $4.17 E-004$ & $4.83 E-\emptyset 04$ & $4.50 E-004$ \\
\hline 3 & 1.00 & $9.16 E-004$ & $1.03 \mathrm{E}-003$ & $9.72 E-004$ \\
\hline 4 & 2.00 & $1.34 \mathrm{E}-003$ & $1.48 \mathrm{E}-003$ & $1.41 \mathrm{E}-003$ \\
\hline 5 & 3.00 & $1.65 E-003$ & $1.82 E-003$ & $1.74 E-003$ \\
\hline 6 & 4.00 & $1.93 E-003$ & $2.05 E-003$ & $1.99 E-003$ \\
\hline 7 & 5.00 & $2.25 E-003$ & $2.28 E-003$ & $2.26 E-003$ \\
\hline 8 & 18.00 & $3.96 \mathrm{E}-003$ & $3.74 E-003$ & $3.85 E-003$ \\
\hline 9 & 46.00 & $5.56 E-003$ & $5.18 E-003$ & $5.37 E-003$ \\
\hline 10 & 91.00 & $6.94 \mathrm{E}-003$ & 6. $44 E-0003$ & $6.59 E-003$ \\
\hline
\end{tabular}

CUMULATIUE FRACTION RELEASE, CO:

$\begin{array}{rrccc}I & T I M E & 85-5-7 & 85-5-0 & \text { AVG } \\ 1 & 0.08 & 1.13 E-006 & 3.07 E-005 & 2.10 E-00 E \\ 2 & 0.29 & 9.91 E-006 & 6.92 E-006 & 8.42 E-006 \\ 3 & 1.00 & 1.68 E-005 & 1.72 E-005 & 1.70 E-005 \\ 4 & 2.00 & 2.81 E-005 & 3.00 E-005 & 2.91 E-005 \\ 5 & 3.00 & 3.44 E-005 & 3.65 E-005 & 3.54 E-005 \\ 6 & 4.00 & 4.19 E-005 & 4.15 E-005 & 4.18 E-005 \\ 7 & 5.00 & 1.57 E-004 & 1.05 E-004 & 1.32 E-004 \\ 8 & 18.00 & 1.80 E-004 & 1.17 E-004 & 1.49 E-004 \\ 9 & 46.00 & 1.94 E-004 & 1.27 E-004 & 1.61 E-004 \\ 10 & 91.00 & 1.96 E-004 & 1.30 E-004 & 1.63 E-004\end{array}$

